\title{
HISTORIAS DE DERECHO Y CIUDADANÍA
}

\section{CATALINA ASCANIO NOREÑA}

\author{
Universidad Santo Tomás \\ Facultad de Economía \\ Maestría en Protección Social \\ Bogotá
}

Noviembre de 2016 


\title{
HISTORIAS DE DERECHO Y CIUDADANÍA
}

\section{CATALINA ASCANIO NOREÑA}

Trabajo de grado para optar el título de Magíster en Protección Social

DIRECTOR: MANUEL VEGA VARGAS

MD. Mg. en Historia, PhD (c) en Historia Docente Universitario Universidad Santo Tomás

Docente Universitario Universidad Externado

\author{
Universidad Santo Tomás \\ Facultad de Economía \\ Maestría en Protección Social \\ Bogotá
}

Noviembre de 2016 
A Carlos Alberto, A mi abuelita Elvia, que me enseñó el sentido cotidiano de la protección social 
Gracias a los cinco protagonistas de esta historia: Margarita, Manuel, Marta, Francisco y José Gracias a Manuel, por el acompañamiento y guía en este proyecto 


\section{Resumen}

La ciudadanía consiste en la relación entre los individuos que habitan un país y el Estado, que ejerce soberanía sobre dicho país a través de un contrato social. Colombia ha suscrito la mayoría de los pactos internacionales en materia de derechos humanos y en la Constitución Política de 1991, ratificó la intención de protección y garantía de los derechos civiles, políticos, sociales y culturales a los ciudadanos, sin embargo las cifras son contundentes a la hora de comprobar el no cumplimiento de lo pactado: la concentración de la propiedad de la tierra, los índices de pobreza, las víctimas del conflicto armado, la informalidad laboral, la baja cobertura del sistema de pensiones, el trabajo infantil, entre otros; lo que evidencia una ambigüedad en el contrato social colombiano.

A través de historias de vida se rastrea la manera como los colombianos construyen la noción de ciudadanía y establecen la relación con el Estado. De esta forma se concluye que en Colombia coexisten diferentes formas de ciudadanía, lo que significa que no todos tienen los mismos derechos. Las cinco trayectorias de vida abordadas en este escrito permiten concluir que entre los extremos de la exclusión y el reconocimiento pleno, se encuentran cinco tipos de ciudadanía: la no ciudadanía, la ciudadanía invertida, la ciudadanía parcial, la ciudadanía plena individual y la ciudadanía plena colectiva; cada una se construye como resultado del lugar de origen, del nivel educativo, del capital social - relacional y sobre todo de la inserción que se haga al mundo laboral y/o el acceso a los medios de producción. 


\begin{abstract}
Citizenship is the relationship between individuals inhabiting a country and the state, which has sovereignty over the country through a social contract. Colombia has signed most of the international covenants on Human Rights and the Constitution of 1991, ratified the intention of protection and guarantee of civil social and cultural rights of citizens, politicians, though the numbers are compelling to when checking non-compliance with the agreement: the concentration of land ownership, poverty rates, the victims of armed conflict, labor informality, low coverage of the pension system, child labor, among others; which shows an ambiguity in the Colombian social contract.

Through life stories tracks how Colombians build the notion of citizenship and establish the relationship with the state. Thus we conclude that in Colombia coexist different forms of citizenship, which means that not everyone has the same rights. The five paths of life addressed in this paper can be concluded that between the ends of exclusion and full recognition, there are five types of citizenship: no citizenship, inverted citizenship, partial citizenship, individual full citizenship and full citizenship collective; each is constructed as a result of the place of origin, educational level, socialrelational capital and especially of the insert is made to employment and / or access to the means of production.
\end{abstract}


Tabla de contenidos

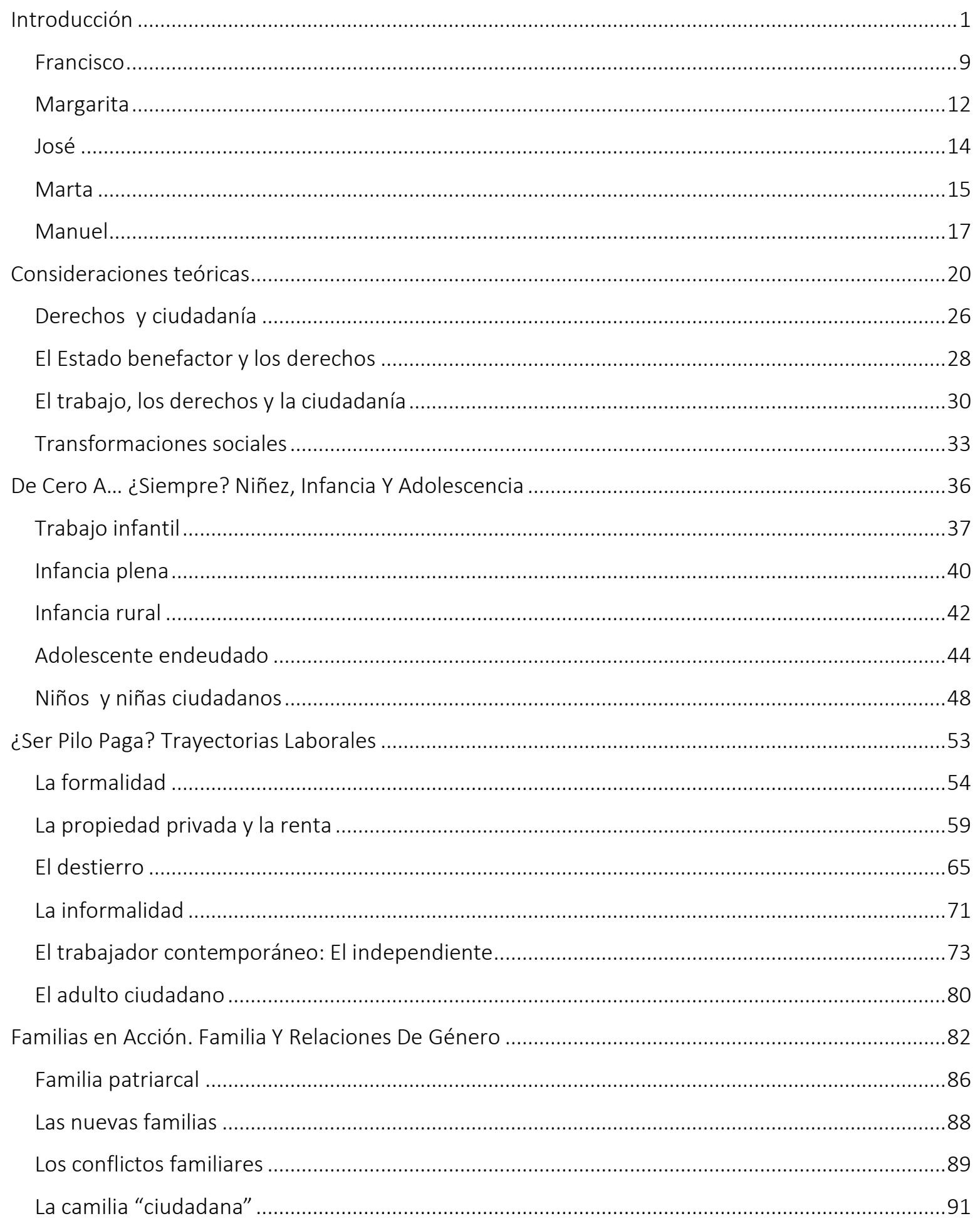




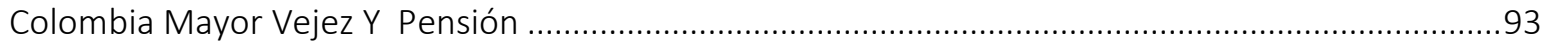

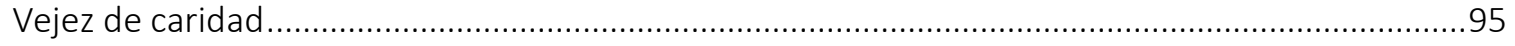

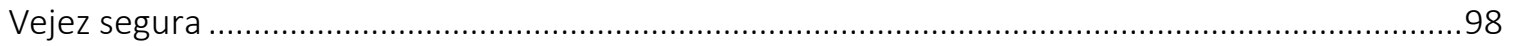

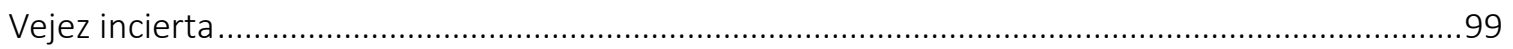

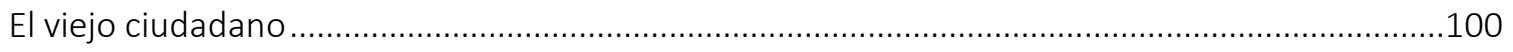

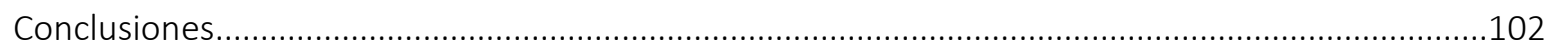

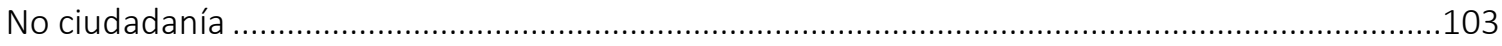

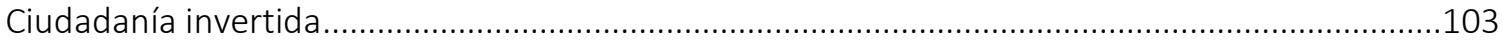

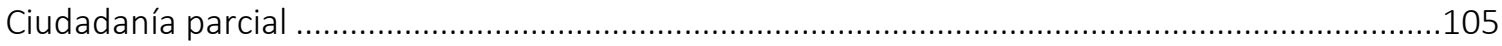

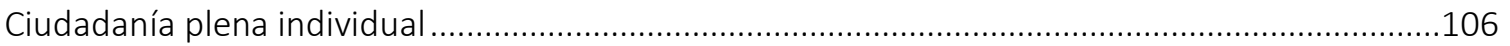

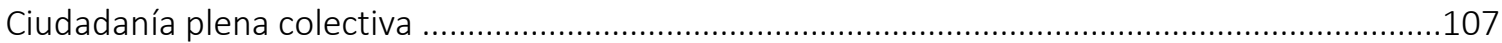

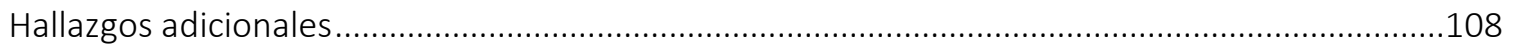

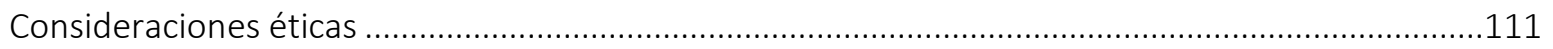

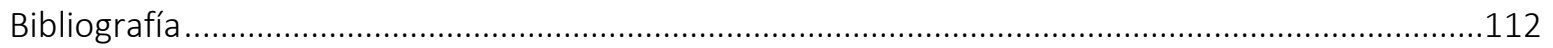




\section{INTRODUCCIÓN}

Durante las últimas décadas Colombia ha disminuido los índices de pobreza pero mantenido

los de desigualdad. Esto significa que si bien han mejorado las condiciones de vida de los colombianos

y su acceso a bienes y servicios, el país continúa siendo inequitativo. Dichas condiciones generan

repercusiones en materia de derechos, ciudadanía y en la relación que los individuos establecen con

el Estado.

Según datos del Departamento Administrativo Nacional de Estadística (DANE), en Colombia

durante los últimos 10 años la pobreza ha tenido una disminución de 10 puntos porcentuales, pasando el 30.4\% en el año 2000 al 20.2\% en el 2015, medida por el Índice de la Pobreza Multidimensional $^{1}$ (IPM). El descenso en estos niveles se evidencia igualmente si se utiliza métodos indirectos, como la medición de pobreza monetaria ${ }^{2}$, que muestra una reducción de 10 puntos porcentuales pasando de 37.2\% en el año 2010 a 27.8\% en el 2015 (DANE, 2016a). Sin embargo, y pese a la clara reducción, el porcentaje de pobreza rural dobla la media nacional y casi triplica el valor

\footnotetext{
${ }^{1}$ El Índice de Pobreza Multidimensional (IPM) fue diseñado en el 2010 por la Universidad de Oxford y el Programa de las Naciones Unidas para el Desarrollo (PNUD) (Caballero, García, \& Vélez C., 2011) y está basado en el enfoque de capacidades. El Departamento Nacional de Planeación (DNP), adaptó y realizó los cálculos del IPM para Colombia con base en las ECV de 1997, 2003, 2007 y 2010. El DANE continuó con el cálculo durante los años 2011 y 2012 (DANE, 2013).

La adaptación para Colombia está compuesta por 5 dimensiones y 15 indicadores: 1 . Condiciones educativas en el hogar: logro educativo, analfabetismo; 2 . Condiciones de la vejez y juventud: asistencia escolar, rezago escolar, acceso a servicios para el cuidado de la primera infancia, trabajo infantil; 3. Trabajo: desempleo de larga duración, empleo formal; 4. Salud: aseguramiento en salud, acceso a servicio de salud dada una necesidad; y 5: Servicios públicos domiciliarios y condiciones de la vivienda: acceso a fuente de agua mejorada, eliminación de excretas, material de pisos, material de paredes exteriores y hacinamiento crítico (DANE, 2013). Son considerados pobres los hogares que tengan privación en por lo menos el 33\% de los indicadores (DANE, 2016a)

2 Los métodos indirectos de medición de pobreza evalúan la capacidad adquisitiva de los hogares respecto a una canasta, para esto observan su ingreso, el cual es un medio y no un fin para lograr la satisfacción (o no privación). Cuando esta canasta incluye todos los bienes y servicios considerados mínimos vitales se habla de pobreza monetaria general, mientras que cuando solo se considera los bienes alimenticios se habla de la pobreza monetaria extrema. Los métodos directos evalúan los resultados de satisfacción (o no privación) que tiene un individuo respecto a ciertas características que se consideran vitales como salud, educación, empleo, entre otras. En Colombia se realiza la medición directa por medio del Índice de Pobreza Multidimensional (IPM) y la indirecta por pobreza monetaria y pobreza monetaria extrema (DANE, 2016a)
} 
urbano; para el año 2015 el IPM en las zonas rurales era 40.0\% y en la ciudades 14.4\% (DANE, 2016a).

Los indicadores de medición de la pobreza con mayor persistencia en el área rural son: el desempleo de larga duración (que ha aumentado los últimos años), las barreras a los servicios de salud, el no acceso a fuentes de agua mejorada, el material inadecuado de las paredes y el trabajo informal. Aquellos que han mostrado reducción son: el aseguramiento en salud, la disminución en el rezago escolar y el bajo logro educativo (DANE, 2016a).

Encontrar al aseguramiento en salud como un indicador de disminución de pobreza que coexiste con las barreras de acceso a los servicios como indicador de pobreza permanente, evidencia la manera como en el país se ha entendido el derecho a la salud. Por un lado, como el aseguramiento cuyo aporte principal es la protección financiera por enfermedad, y por otro como el acceso concreto, pertinente y de calidad a servicios dirigidos al mejoramiento de la salud de la población. Tener afiliación al sistema general de seguridad social en salud pero no acceder a los servicios evidencia la no garantía de este derecho.

En relación con la desigualdad, el índice de $\mathrm{Gini}^{3}$ en Colombia ha presentado discretas reducciones. Para el año 2000 se encontraba en 58,7 y en el 2013 en 53,5; su máxima expresión ocurrió durante el año 2006 cuando se ubicó en 60.1 (Banco Mundial, 2016). Según datos del Banco Mundial, Colombia ocupa el doceavo lugar como el país más desigual del mundo, y en la región Latinoamericana y del Caribe, el segundo lugar precedido por Honduras con un índice de 53.7, seguido por Belice, Brasil y Guatemala con Gini de 53.3, 52.9 y 52.4 respectivamente (Banco Mundial, 2014).

\footnotetext{
${ }^{3}$ El índice de Gini mide hasta qué punto la distribución del ingreso (en algunos casos el gasto de consumo) entre individuos u hogares dentro de una economía se aleja de una distribución perfectamente equitativa. Un índice de Gini de 0 representa una equidad perfecta, mientras que un índice de 100 representa una inequidad perfecta.
} 
Los factores con mayor impacto en este índice son la distribución de la tierra y el nivel de ingreso de la población. En cuanto a la propiedad de la tierra, Rodríguez y Cepeda encontraron que para el año 2000 en Colombia, el 57.1\% de los propietarios tenían el 3\% de la tierra y el $97 \%$ de tierra restante le pertenecía al 41,6\% de los propietarios (Rodríguez \& Cepeda, 2011); esto significa un índice Gini rural de 0.84. Los departamentos con mayor nivel de concentración de tierra son aquellos que conforman el piedemonte llanero, Antioquia y Valle del Cauca.

Diferentes investigaciones coinciden en que la concentración en la propiedad de la tierra se encuentra ligada al conflicto armado interno y potencializada por el limitado acceso que tiene la población campesina a los servicios y protección del Estado (IGAC, 2012; Rodríguez \& Cepeda, 2011). Lo que advierte sobre la vulneración de derechos de esta población en cuanto a la protección de la vida, la propiedad privada y los derechos sociales.

Respecto al nivel de ingresos, según análisis y cálculos de Talero (2015), el 80\% de los hogares en Colombia presentan niveles de ingreso per cápita inferiores al salario mínimo, de este grupo la mitad se encuentra por debajo de la línea de pobreza ${ }^{4}$ y los demás por encima, es decir entre la línea de pobreza y el salario mínimo. El 20\% de los hogares restantes tiene ingresos per cápita superiores al salario mínimo mensual. Según sus cálculos, en Colombia un hogar conformado por dos personas adultas y un niño recibe un ingreso promedio de $\$ 1.100 .000$ mensuales con un $80 \%$ de probabilidad (Talero B, 2015)

Dichos contrastes y ambigüedades son permanentes en la cotidianidad de los colombianos y suceden en la democracia más antigua del continente. Suceden en un país concebido como:

\footnotetext{
${ }^{4}$ La línea de pobreza es el costo per cápita mensual mínimo necesario para adquirir una canasta de bienes (alimentarios y no alimentarios) que permitan un nivel de vida adecuado en un país determinado. Para 2015, el costo per cápita mínimo necesario a nivel nacional fue de $\$ 223.638$ (DANE, 2013)
} 
"un Estado Social de Derecho... democrático, participativo y pluralista, fundado en el respeto de la dignidad humana, en el trabajo y la solidaridad de las personas que lo integran y en la prevalencia del interés general". En el cual se han definido como fines esenciales del Estado: "servir a la comunidad, promover la prosperidad general y garantizar la efectividad de los principios, derechos y deberes consagrados en la Constitución" (Artículo 1 y 2 de la Constitución Política de Colombia, 1991).

Las cifras de pobreza y desigualdad expresan claramente que, pese a la claridad con que son establecidos los derechos en el ordenamiento constitucional, la sociedad colombiana enfrenta cotidianamente la vulneración de los mismos con diferencias importantes entre grupos sociales, género, regiones y campo y ciudad. De hecho, los procesos que permiten la captura de datos para construir los indicadores estadísticos, en ocasiones no logran reflejar la situación variable y cambiante, el carácter procesual y la naturaleza multidimensional de la ciudadanía de derechos de amplios sectores de la población, ya que generalmente son numéricos y de medición transversal.

Cientos de situaciones de vulneración de derechos que suceden a lo largo del proceso vital y de la cotidianidad de las personas, no logran ser capturadas por aquellas encuestas que, con base al auto reporte, suponen, tanto registros estáticos de las condiciones de vida de las personas, como instrumentos limitados a una imagen fragmentaria de las condiciones de ciudadanía. Es claro que este tipo de estudios no permite ver adecuadamente la condición compleja, procesual y dinámica de la ciudadanía y los derechos de las personas.

Pero tampoco parece ser suficiente atenerse a las respuestas que proveen los colombianos cuando se les pregunta directamente sobre su condición de ciudadanía y sobre las nociones con las que explican dicha situación, ya que las respuestas generalmente se dirigen a aquello que es 
políticamente correcto afirmar o a conceptos generales y repetidos sobre los que no se hace habitualmente un cuestionamiento. Es preciso preguntarse cómo se podría acceder a los procesos de ciudadanía de los colombianos y hasta qué punto es posible evidenciar las vulneraciones o afirmaciones de derechos registradas en las experiencias cotidianas y en la trayectoria de vida.

Por tal razón, la pregunta central de esta investigación es: ¿Cómo construimos los colombianos las nociones de derechos y ciudadanía, en medio de un contrato social, en el cual existe diferencia entre lo definido en la normatividad y los hechos, las decisiones y la cotidianidad?

Es por eso que el objetivo general es analizar los procesos de construcción de las nociones de derecho y ciudadanía a través de cinco historias de vida y los objetivos específicos son: describir cómo entienden los colombianos su relación y participación en el Estado, analizar el significado de los derechos y ciudadanía como categoría relacional en la vida cotidiana y aportar elementos en pedagogía para la paz necesaria en el postconflicto.

Para responder a este cuestionamiento se desarrolló una metodología cualitativa, de historia de vida ${ }^{5}$ análisis documental, siendo la primera un potente método de investigación descriptiva para conocer cómo las personas entienden y viven el mundo social (Chárriez, 2012), que además ofrece un marco interpretativo a través del cual el sentido de la experiencia humana se revela en relatos personales, de modo que da prioridad a las explicaciones individuales y, por lo tanto, supera la transversalidad de las entrevistas y las encuestas.

Según Ruiz citado por Chárriez (2012) la historia de vida busca descubrir la relación dialéctica, la negociación entre aspiración y posibilidad de la vida cotidiana, del sentido común, de las

\footnotetext{
${ }^{5}$ Se llevaron a cabo sesiones de conversación y aplicación de los instrumentos de historia de vida con las 5 personas, previa aprobación y consentimiento informado de cada uno. Estas sesiones se complementaron con la búsqueda de información sobre las situaciones expresadas, los contextos históricos, geográficos y la situación social y política, hasta donde fue posible.
} 
explicaciones y reconstrucciones que el individuo efectúa para vivir y sobrevivir diariamente, puesto que ofrece un marco interpretativo a partir de la experiencia humana.

Abordar este tema desde una perspectiva cualitativa a través de la historia de vida, supone en palabras de Bourdieu (1993), que "no hay experiencia en el macrocosmos social que no esté determinada o, al menos no sea modificada, por el efecto directamente experimentado de las interacciones sociales dentro de esos microcosmos sociales"(Bourdieu, 1993, p. 10). Dichos microcosmos están construidos por el enfrentamiento de visiones del mundo diferentes o antagónicas, fundadas en la expresión de disímiles realidades y discursos.

La investigación tuvo cuatro fases: la primera se trató de un análisis documental en el cual se discutieron y analizaron los aspectos relativos a la pregunta de investigación y las bases teóricas y conceptuales que orientaron la exploración. En la segunda fase se definieron perfiles de los personajes. Al respecto, se aclara que si bien la metodología cualitativa no busca ser representativa, a la hora de seleccionar a los protagonistas para esta investigación se decidió tener participación tanto de hombres como de mujeres, y de personas de lugar de nacimiento diferente y de ocupaciones heterogéneas; intencionalmente se buscó a un sujeto víctima del conflicto armado por ser esta condición característica del país.

En la fase siguiente fueron contactadas, directamente por la investigadora, cada uno de las personas seleccionadas y se acordaron dos encuentros con cada una, en el primero de ellos se explicó el objetivo de la investigación, se preguntó por el deseo de participar, se pidió autorización verbal para ser grabado y se inició la narración, en el segundo se hicieron precisiones sobre el relato; cada encuentro duró aproximadamente 90 minutos. Posteriormente los diálogos fueron transcritos y el nombre de las personas cambiado. El grupo de personajes está compuesto por dos mujeres y tres 
hombres, actualmente todos viven en la ciudad de Bogotá y se encuentran entre los 31 y 59 años.

En la fase final, se realizó el análisis de la información recolectada, se manejaron dos niveles de análisis, el primer nivel fue intra caso, en el cual se analizaron y trabajaron en profundidad cada historia relatada; a idea fue poder llegar a una historia reconstruida y contrastarla con el análisis documental realizado, además de buscar otras fuentes bibliográficas para enriquecer el análisis. El otro nivel de análisis fue el inter caso utilizado para determinar los ejes temáticos - analíticos relevantes e hipótesis comprensivas transversales para abordar la pregunta de investigación.

Para presentar los resultados se opta por un esquema que permita transitar por las historias de vida de cada personaje, dialogar con la teoría y contrastar las diferentes realidades; es por eso que el escrito parte de los recuerdos que cada uno tiene acerca de su infancia, posteriormente se sitúa en la vida laboral - productiva, continua con las referencias sobre la familia y termina con las proyecciones que se tengan sobre la vejez. Los relatos se nutren con algunos datos sociodemográficos, políticos y económicos sobre el contexto en que los relatos suceden, sin embargo no se llega a un análisis socio histórico de cada una de las trayectorias y la postura desde la que se abordan es más cercana al curso de vida.

Vale anotar que la noción de ciudadanía y derechos es central en la protección social, puesto que es alrededor del reconocimiento de derechos y de la consolidación de la ciudadanía que ésta se ha construido en diferentes momentos y lugares; siendo hoy todavía un tema complejo y cambiante que produce profundas discusiones. Adicionalmente, la sociedad colombiana es profundamente plural por lo que para poder entender las particularidades y yuxtaposiciones que la definen, es necesario adentrarse en la realidad y cotidianidad de los individuos, conociendo su día a día y las especificidades que escapan a metodologías cuantitativas pero que a la vez podrían contribuir a la 
política pública y de ahí su importancia. Es por eso que la metodología de historias de vida aporta en la tarea de entender el proceso de construcción de ciudadanía en el contexto colombiano particular, ya que permite una exquisita relación entre lo micro y lo macro social, aspecto frecuentemente olvidado en las discusiones sobre política pública, protección social e inclusive ciudadanía.

En las páginas siguientes se analizan los procesos de construcción de las nociones de derecho y ciudadanía a través de cinco historias de vida. Este escrito consta de siete capítulos: el primero recoge la conceptualización teórica desde la que se hace el análisis; en los cuatro siguientes se presenta la reconstrucción de las etapas del curso de vida desde el reconocimiento de los derechos, organizándose de la siguiente manera: el segundo capítulo aborda los derechos y la ciudadanía en la infancia, el tercero en la edad adulta y productiva, el cuarto en las relaciones familiares y el quinto en las proyecciones para la vejez. Posteriormente hay un apartado de conclusiones de acuerdo a los tipos de ciudadanía encontrados y finamente una sección sobre consideraciones éticas.

Los protagonistas de este relato son Francisco, Margarita, José, Marta y Manuel, cinco personas que revelan a través de sus vidas, cómo se construyen las nociones de derecho y ciudadanía de los colombianos.

A continuación se realiza la presentación de los protagonistas, exponiendo aspectos de su vida, contexto social y económico y otros elementos que ponen en evidencia su representatividad en la sociedad colombiana. 


\section{FRANCISCO}

Francisco es el hijo del medio, tiene dos hermanas, describe su familia como una "típica familia ibaguereña", sus padres se casaron siendo muy jóvenes y la madre se dedicó a los cuidados de la casa y los hijos, su padre era el empleado estrella de una empresa de calzado. Francisco nació y vivió los primeros años en Ibagué; cuando tenía tres años su padre ascendió laboralmente, por lo que fue trasladado a Florencia (Caquetá) con la misión de ampliar el mercado de la empresa de calzado para la que trabajaba.

En Florencia, durante una reunión de negocios en una cafetería, un grupo guerrillero llegó al lugar con la intención de secuestrar a uno de los asistentes, en el intercambio de disparos entre el ejército y el grupo guerrillero, fue herido el padre de Francisco y murió a los 31 años de edad por una bala del Ejército.

En razón a la muerte del padre de Francisco, la madre recibió la pensión de sustitución. El seguro de vida comprado por el crédito hipotecario saldó su deuda, por lo que la familia pudo vender la casa y retornar a Ibagué. La madre de Francisco, viuda con tres hijos y 29 años, se empleó por primera vez como operaria de máquina en una empresa de camisetas, a la vez que empezó estudios universitarios en ingeniería textil.

Francisco terminó el bachillerato con un excelente rendimiento académico y decidió estudiar medicina, ingresó a una universidad privada para lo cual solicitó un crédito educativo en una institución gubernamental. La madre de Francisco inició su propia empresa de fabricación de camisetas enviándole algunas a su hijo, quien para su manutención las vendía en Bogotá. Con préstamos y trabajo Francisco terminó la carrera. 
Por razones económicas, realizó el servicio social obligatorio en Casabianca y trabajó un par de años más para cancelar la deuda económica adquirida por el estudio universitario. Tres años después retomó la vida en Bogotá, con su red de amigos logró un trabajo temporal en una institución gubernamental, y un año después concursó en la Comisión Nacional de Servicio Civil, obteniendo un cargo de carrera administrativa en el sector público.

Desde ese día han pasado siete años, hoy Francisco tiene 35 años, no tiene deudas, ha realizado estudios de posgrado y tiene un patrimonio de aproximadamente 400 millones de pesos. Entre sus planes está continuar su capitalización, lograr estabilidad económica y esperar la llegada de una compañera para compartir su vida. Actualmente dedica el tiempo libre a tocar guitarra en uno de los cursos ofrecidos por su empresa a los trabajadores. Para su vida futura sueña con abrir una empresa de camisetas en Ibagué.

Respecto al contexto de Francisco, existen dos aspectos sobre los cuales se debe hacer énfasis para entender su construcción de la noción de derechos y ciudadanía: la vinculación laboral formal y el acceso a la educación superior.

El Ministerio de Educación Nacional señala que en el 2015 la tasa de cobertura de la educación superior en Colombia fue del 48,9\%, (Ministerio de Educación Nacional, 2016). Para realizar este cálculo se consideró no sólo el acceso a la universidad, sino también el acceso a la educación técnica y tecnológica. Francisco ingresó a la universidad en el año 1996; en las estadísticas disponibles del Ministerio de Educación Nacional el dato más antiguo es de 2002, con una tasa de cobertura del 23,7\% para educación universitaria, técnica y tecnológica (Ministerio de Educación Nacional, 2016). Por lo tanto, es difícil conocer el porcentaje de personas que ingresaron a la educación superior cuando lo hizo Francisco, pero la tendencia muestra que la cifra ha venido 
aumentando progresivamente, lo que permite concluir que en el año 1996 la proporción de personas que accedían a la educación superior era mucho menor al 20\%.

Los datos del Ministerio de Educación Nacional, además de no discriminar entre la educación universitaria, técnica y tecnológica, tampoco diferencian entre los niveles de pregrado y posgrados, es decir, que en la tasa de cobertura de la educación superior para 2015 calculada en 48,9\%, se contabilizó a quienes ingresaron a formación técnica, tecnológica, universitaria y todos los niveles posgraduales.

En relación al trabajo, el tener un contrato laboral implica el cumplimiento de las horas laborales semanales, un salario fijo, el pago de las horas extras y dominicales, vacaciones, prima, cesantías y caja de compensación familiar. La relación patrono-laboral está enmarcada en el código sustantivo del trabajo y otros convenios internacionales suscritos por el país para la protección del trabajador, es en general una fuente de protección.

El sector público aporta la mitad de los trabajadores formales en Colombia. Según el Ministerio del Trabajo para 2011 el universo de trabajadores era 20.016.843, de los cuales 809.475 eran empleados del sector público; siendo el 51,8\% hombres. Son pocos los trabajadores que tienen un contrato formal (Ministerio del Trabajo, 2012).

Francisco fue de alguna manera privilegiado ya que como pocos, accedió a la educación superior y su vida laboral la ha desarrollado mediante un contrato laboral formal. Su historia permite conocer las trayectorias de los profesionales que logran una inserción formal en el mundo del trabajo. 


\section{MARGARITA}

Margarita es una de las 635.000 empleadas domésticas que según el Ministerio de Trabajo existen en Colombia (Ministerio del Trabajo, 2012). Tiene 59 años, nació y ha vivido toda su vida en Bogotá, ocupa el segundo lugar en una familia de cinco hermanos, tres hombres y dos mujeres, y es la segunda en orden de nacimiento. Su madre es de origen campesino y su padre es bogotano.

Cuando tenía 7 años, por decisión de sus padres fue dejada al cuidado de una señora para que "tuviera un mejor futuro", ninguno de sus hermanos corrió con la misma suerte. En ese momento empezó su vida como empleada doméstica. En casa de su nueva familia, Margarita tuvo que realizar todas las labores domésticas en horas de la mañana para poder asistir en las tardes a estudiar, en las noches cuando tenía tiempo y poco cansancio veía telenovelas.

En esas condiciones Margarita terminó su infancia y parte de la adolescencia. A los 12 años a causa del exceso de trabajo y la nostalgia por estar lejos de los suyos, partió de nuevo a casa de sus padres con su ropa y su título de primaria de un colegio distrital, no cursó bachillerato, no hubo sueldo, ni liquidación, ni cesantías, ni nada parecido el día de partió de esa casa.

Años después de vuelta al hogar de sus padres y por influencia de una amiga, Margarita comenzó a vender sábanas al detal, tuvo tanto éxito en su nuevo oficio que pronto consiguió trabajo como vendedora de telas, donde por primera y única vez supo qué era una jornada laboral y un salario por su trabajo.

En su nuevo oficio conoció a Juan, con quien se casó después de un año de relación; al poco tiempo de casados tuvieron a su primera hija: Marcela, y un año después a la segunda: Claudia. Debido a problemas económicos Margarita, Juan, Marcela y Claudia se trasladaron a vivir con los padres de Juan, participando en el negocio familiar: restaurante-billar. 
Los cinco años en la compañía de los suegros fueron de estabilidad y progreso financiero; sin embargo por peleas al interior de su familia política y malos manejos económicos, la familia de Margarita abandonó ese hogar y se instaló en la casa de sus padres. Al volver a casa de los padres de Margarita, Juan abandonó la familia. Ante esa situación, Margarita fue invitada por su hermana a desempeñarse como empleada doméstica.

Han pasado 18 años después de la retoma de su oficio de infancia, siempre mediante contrato verbal y adquiriendo clientes voz a voz. Con su trabajo logró pagarles a sus hijas el bachillerato, hoy continúa viviendo en casa de sus padres, quienes residen ahora en la finca de la madre. Comparte la casa con dos de sus hermanos y su hija mayor, pertenece al régimen subsidiado en salud, nunca ha tenido un contrato laboral, siempre ha estado en la informalidad, sus activos son sus muebles y jamás ha cotizado al sistema de pensiones.

Margarita encarna la historia de muchas mujeres empleadas domésticas, las cuales según Portafolio eran 753.333 en Colombia para el año 2013, de las cuales el 95\% son mujeres (715.666) y el resto hombres (37.667). Sin embargo y pese a constituir el 3,5\% de las ocupaciones totales en el país, tienen condiciones laborales deficitarias ya que solo el $8 \%$ posee un contrato escrito, mientras el porcentaje restante tiene un convenio verbal (Portafolio, 2013).

Aunque el $88 \%$ de estas personas están afiliadas o cotizan a la seguridad social, sólo el 33\% lo hace a través del régimen contributivo. El 15\% cotizan pensión o se encuentran jubiladas, y tan sólo el 5,5\% están afiliadas a una caja de compensación familiar, lo que demuestra la poca formalización del sector; además el 3\% de este renglón de la economía tienen entre 10 y 17 años (Portafolio, 2013). 


\section{JOSÉ}

José acaba de cumplir 50 años. Fue una celebración sencilla, asistieron sólo los familiares y amigos cercanos, no más de 30 personas. El día de la celebración doña Cecilia, madre de José, mencionó que se encontraba orgullosa de poder celebrarle el cumpleaños número cincuenta al segundo de sus cuatro hijos.

El padre de José migró a muy temprana edad del campo a Bogotá, al llegar a la ciudad trabajó como vigilante de una empresa de tipografía, doña Cecilia trabajó en la misma empresa en la sección de encuadernación, ambos ascendieron de posición y al cabo de 38 años se pensionaron.

José estudió en el colegio del barrio, siempre tuvo mal rendimiento académico por lo que cambió de colegio con frecuencia; a los 14 años decidió ingresar a estudiar en jornada nocturna y trabajar durante el día con una máquina tarjetera comprada por su padre, rápidamente consolidó una clientela que le exigió tener entre cuatro o cinco operarios trabajando para él.

Su naciente negocio fue tan próspero que al terminar el colegio nunca pensó en ingresar a la universidad, por el contrario se dedicó a hacer crecer su empresa y multiplicar el capital; así fue como con las ganancias de las artes gráficas a los 17 años compró una buseta de servicio público, al corto tiempo la vendió y compró una buseta de transporte especial, luego otro par de busetas para las cuales contrató conductores.

A los treinta años decidió invertir en finca raíz y comprar una casa que convirtió en varias bodegas, en una de ellas instaló su empresa de artes gráficas y las otras las arrendó; los negocios le permitieron comprar otras cuantas bodegas y un lavadero de carros. 
Está casado, tiene dos hijas que estudian en universidades privadas; en el sistema de seguridad social en salud es beneficiario de su esposa y jamás ha cotizado a pensiones; tiene 50 años y vive de la renta. Afirma nunca haber pasado por el sistema financiero para hacer negocios, los cuales realiza en efectivo o con letras de cambio; no tiene deudas y paga puntualmente sus obligaciones tributarias.

José pertenece al selecto grupo de los denominados como patrón-empleador por el Ministerio de Trabajo, que para el año 2011 sumaban un total de 987.571 representando el 4,9\% del total de ocupados (Ministerio del Trabajo, 2012). Su historia refleja la trayectoria de los pequeños empresarios colombianos durante los últimos 30 años.

\section{MARTA}

En 1985 la ciudad de Tunja tenía 93.966 habitantes (DANE, 2015); en ese año y en una familia nuclear tradicional nace Marta, siendo la última de los hijos, precedida por un hermano y una hermana; a los cuatro años de vida los padres de Marta se divorciaron. Mientras asistía al colegio, a los 8 años empezó a ir simultáneamente a la escuela de música, siendo ésta su entrada al mundo artístico.

Cuando terminó el bachillerato después de varias y profundas dudas, ingresó a estudiar Artes Plásticas en una Institución de Educación Superior de renombre nacional e internacional. El transcurso en la universidad sucedió sin inconvenientes, terminando su formación en el año 2010.

Al finalizar la universidad, un poco decepcionada por el cerrado círculo del arte de élite, salió del país para aprender otro idioma y explorar nuevos horizontes. De regreso a Colombia, buscó la 
posibilidad de insertarse en el mundo laboral, pero al no tener éxito decidió nuevamente migrar para realizar estudios de posgrado y mejorar su perfil profesional con el interés de incrementar sus posibilidades laborales. Finalizados sus estudios de posgrado y de nuevo en el país, las pocas oportunidades laborales las ha conseguido gracias a convocatorias o proyectos, pero todos con elementos en común: son escasos, fugaces, requieren mucho trabajo previo y son muy competidos.

Respecto a lo personal, tiene una relación estable desde hace varios años y actualmente convive con su pareja; no tiene ingresos fijos, no tiene seguridad social y se encuentra a la espera de la respuesta del último proyecto presentado; todos los días fabrica separadores de libros y aretes que vende en la calle.

Es difícil saber cuántos artistas existen en Colombia, fundamentalmente porque para serlo se puede llevar a cabo un proceso educativo en una institución formal o también se puede llegar a ser sin ningún tipo de instrucción. Sin embargo, si se acude a las estadísticas del Ministerio de Educación, el Observatorio Laboral reporta que en el año 2013 hubo 10.837 graduados en el área de Bellas Artes, lo que significa un 3.1\% del total de graduados del país (Ministerio de Educación Nacional, 2013).

Si bien como grupo, los artistas no son mayoritarios, su importancia en la sociedad radica en el aporte que hacen, son los artistas en cualquiera de sus manifestaciones los encargados de narrar, reflejar, crear, actuar y cantar la historia y la realidad, son en un gran aporte en la construcción de la memoria colectiva.

La historia de Marta hace pensar que respecto al arte aún nos encontramos en épocas de Van Gogh, quien tuvo que cambiar sus telas por verduras en las tiendas del vecindario para poder comer; empero el precio actual de una sola de sus obras le habría permitido vivir como rico la vida 
entera. El éxito, el reconocimiento y la fortuna le llegaron después de muerto, debido a la incapacidad de su sociedad de reconocer el arte y su importancia.

\section{MANUEL}

Chámeza es un municipio del departamento de Casanare, según el DANE en el año 1985 tenía 1.805 habitantes y para el año 2015 su población había aumentado a 2.460 (DANE, 2015); no hay datos oficiales respectos a cuántos habitantes tenía hace 51 años cuando nació Manuel. Ha sido un municipio agrícola, ganadero y fuertemente golpeado por la violencia debido a la presencia de grupos armados al margen de la ley: frentes de las FARC, el EPL y en épocas de la seguridad democrática, grupos paramilitares.

Al rastrear este municipio en noticias nacionales los pocos resultados se relacionan con el conflicto armado interno, tal como el asesinato de la alcaldesa en 1994, al parecer a manos de un grupo guerrillero. La misma nota de prensa llama la atención sobre la pobreza del municipio y recalca que su presupuesto anual llega a treinta millones de pesos (El Tiempo, 1994). Noticias más recientes alertan sobre enfrentamientos entre las FARC y las autodefensas campesinas del Casanare (ACC) con población civil de por medio (El Tiempo, 2001). Otras noticias hacen mención a la corrupción de sus funcionarios públicos (El Espectador, 2015).

En este poblado nació y vivió Manuel, es el tercer hijo de seis hermanos, sus padres y toda su familia se han dedicado a las labores agrícolas, cuando niño dividía su día entre la asistencia a la escuela rural donde aprendió a leer y escribir, y las labores del campo en la finca propiedad de su familia. No hubo estudios posteriores a la primaria; tempranamente se ocupó como jornalero en fincas vecinas y a los 16 años con el fruto de su trabajo empezó a aportar económicamente a su casa. 
A los 20 años decidió buscar mejor futuro y emprendió camino a Paz de Ariporo, donde encontró trabajo en una finca ganadera; dos años después se casó con una de las hijas del dueño, gracias a esta unión recibió un predio para el sustento de su familia. Fueron siete años de progreso al cabo de los cuales, con colaboración de su esposa, fue acusado por un grupo guerrillero de complicidad con los grupos paramilitares, imponiéndole tres días para abandonar esa tierra bajo amenaza de perder la vida.

Después de este suceso volvió a casa de sus padres y al poco tiempo se instaló en el pueblo inaugurando una panadería y una peluquería; el cliente mayoritario para ambos negocios era el grupo guerrillero con presencia en la región, cada día la guerrilla le compraba 200 panes y cada domingo enviaba entre 10 o 15 combatientes para usar los servicios de peluquería.

Con la llegada de los grupos paramilitares a Casanare y en particular a Chámeza, fue acusado de pertenecer al grupo guerrillero por lo que fue secuestrado y torturado por 15 días, una vez puesto en libertad tuvo un par de días para abandonar el pueblo dejando todas sus pertenencias y familia.

Huyó a Sogamoso y semanas después se trasladó a Bogotá con un trabajo como aseador de máquinas. Hizo el registro como víctima y por ello recibió alimentación por dos meses. Una vez en el nuevo trabajo, gracias a su constancia y perseverancia, ha podido capitalizarse y ahora es el proveedor de alimentación en una empresa constructora.

Colombia ha vivido el conflicto armado interno más largo del continente, los enfrentamientos entre los grupos guerrilleros, paramilitares y la fuerza pública han tenido a la población civil en medio. Según el Registro Único de Víctimas (RUV) a septiembre de 2016 en el país había 8.190.451 víctimas del conflicto armado interno, de las cuales 1.710 se encuentran reportadas en el municipio de Chámeza (Registro Único de Víctimas, 2016). De todos los delitos tipificados en el marco del 
conflicto $^{6}$, los tres más frecuentes son: en primer lugar el desplazamiento forzado con 79,9\% que representa 6.937.205 de colombianos desplazados ${ }^{7}$; en segundo lugar el homicidio con un $11.3 \%$ (978.906 personas asesinadas); y en tercer lugar la amenaza con 3.7\% lo que constituye 317.468 colombianos amenazados con ocasión del conflicto. La historia de Manuel, refleja el estado de derechos y la condición de ciudadanía de las personas víctimas del conflicto armado (Registro Único de Víctimas, 2016).

${ }^{6}$ Los delitos tipificados en el marco del conflicto colombiano según el RUV son: 1) abandono o despojo forzado de tierras; 2) acto terrorista/atentados/combate/hostigamiento; 3) amenaza; 4) delitos contra la libertad y la integridad sexual; 5) desaparición forzada; 6) desplazamiento; 7) homicidio; 8) minas antipersona/munición sin explotar/artefacto explosivo; 9) pérdida de bienes muebles e inmuebles; 10) secuestro; 11) tortura; 12) violación de niños, niñas y adolescentes; y 12) sin información.

${ }^{7}$ En el año 2015 Colombia tenía el mayor número de desplazados internos en el mundo, le seguía Siria e Irak.(El País, 2016) 


\section{CONSIDERACIONES TEÓRICAS}

Dos ideas son el fundamento de lo que hoy conocemos como Derechos Humanos: la igualdad y la dignidad humana. Sin bien estas ideas pueden rastrearse en pueblos antiguos, nunca fueron hegemónicas, al contrario lo era la idea de conquistar o dominar a todo a aquel que por oficio, lugar de nacimiento, raza o religión fuera diferente; en algunas sociedades continúa vigente esta noción.

Fue necesaria la revolución francesa y dos guerras mundiales para que los países reconocieran la necesidad de acordar los Derechos Humanos. Sólo después de la Segunda Guerra Mundial en septiembre de 1945, con delegados de 51 países se constituyó la Organización de las Naciones Unidas. En esa institución bajo la tutoría de Eleanor Roosevelt, se logró consolidar y publicar la Declaración Universal de los Derechos Humanos (Rights, 2008).

La Declaración proclama los derechos inherentes a todos los seres humanos:

"La ignorancia y el desprecio de los derechos humanos han resultado en actos de barbarie ultrajantes para la conciencia de la humanidad, y la llegada de un mundo donde los seres humanos gocen de libertad de expresión y creencia y sean libres del miedo y la miseria se ha proclamado como la más alta aspiración de la gente común... Todos los seres humanos nacen libres e iguales en dignidad y derechos" (Organización de las Naciones Unidas, 1948).

Después de su proclamación, los países miembro de las Naciones Unidas se comprometieron a trabajar juntos para promover los 30 Artículos que por primera vez en la historia, se reunieron y sistematizaron en un solo documento. En consecuencia, muchos de esos derechos son parte de las constituciones de las naciones democráticas en la actualidad.

Pero si bien todos los países miembros están comprometidos con el respeto y cumplimiento 
de lo consignado, cada uno define el contenido, los mecanismos para hacerlos realidad y la justiciabilidad de dichos derechos. En general, la concreción de los derechos suele ser sencilla en cuanto a los civiles y políticos, pero muy controvertida respecto a los derechos económicos, sociales y culturales, cuya inclusión dentro de la ciudadanía se basa fundamentalmente en "el derecho a un nivel de vida adecuado" consagrado en el artículo 11 del Pacto de Derechos Económicos, Sociales y Culturales (CEPAL, 2005).

Se considera entonces que la ciudadanía consiste en la relación entre los individuos que habitan un país y el Estado, que ejerce soberanía sobre dicho país a través de un contrato social, (Giraldo, 2008) es el espacio de los derechos (Moyn, 2015) definidos en un territorio y época particular (Arendt, 1982).

El contrato social colombiano es el reflejo de la ambigüedad presente en la Constitución Política, que por un lado postula la protección de los derechos individuales y colectivos a través de la defensa del Estado Social de Derecho, y por otro consolida un modelo de desarrollo económico inspirado en el neoliberalismo con la consecuente reducción del Estado y sus protecciones. Es una Constitución que pretender mezclar el agua y el aceite, que bajo el argumento de la defensa de la libertades individuales, minimiza la intervención estatal y posiciona al mercado como árbitro imparcial de las relaciones sociales (Múnera, 2007).

Los años que precedieron a la Constitución del 91, estuvieron marcados por sucesos trascendentales. En el contexto internacional, el mundo occidental se encontraba en un ambiente de ajuste estructural, promovido por el Banco Mundial y el Fondo Monetario Internacional, quienes dieron a los países de América Latina una especie de recetario de políticas económicas llamado “El 
Consenso de Washington"8 (1989), las cuales eran las reglas con las que los países debían renegociar sus deudas externas y establecer nuevos pactos con los países desarrollados (Cruz, 2010). Este hecho, significó una fuerte presión para el direccionamiento de los países latinoamericanos hacia el reemplazo de la industria doméstica por una consolidada sociedad de mercado, con un Estado cada vez más pequeño.

En el entorno regional, se hacía tránsito de gobiernos dictatoriales a gobiernos democráticos, como es el caso de Chile, Brasil y Argentina en medio del estancamiento económico, la limitación de acceso a los capitales internacionales, la disminución del ingreso per cápita y la gran inflación (“la década perdida de América Latina"). En el contexto nacional, se vivía el aumento del narcotráfico y su guerra contra el Estado, el fortalecimiento de los grupos guerrilleros, el surgimiento de los grupos paramilitares, la destrucción del movimiento político Unión Patriótica, la reforma laboral y la tendencia a la resolución coactiva de los conflictos sociales, todo lo cual llevó al recrudecimiento de la violencia y la notoria disminución de espacios para la participación ciudadana (Cruz, 2010; Díaz, 2009).

Estas realidades opuestas, se traducen en exigencias divergentes; por un lado se exige al Estado que priorice sus acciones encaminadas al bienestar social de la población, vía reconocimiento de derechos; y por el otro la exigencia internacional de imposición de un modelo económico, donde los derechos son transados con las reglas del mercado y el Estado actúa como corrector ante las fallas que presenta este modelo. Estas divergencias hicieron conflictiva la definición de políticas a todo

\footnotetext{
8 Recomendaciones económicas sobre: 1.Disciplina fiscal; 2.Disminución de gasto público; 3. Mejora de la capacidad impositiva sobre la base de la extensión de los impuestos indirectos; 4.Liberación del sistema financiero y de la tasa de interés; 5.Mantenimiento de un tipo de cambio competitivo; 6.Liberación comercial externa; 7. Otorgamiento de amplias facilidades a las inversiones extranjeras; 8.Privatización de las empresas públicas; 9.Cumplimiento estricto a los compromisos de deuda; y 10.Protección de derecho a la propiedad.
} 
nivel.

La ambigüedad de la Constitución del 91 radica en el reconocimiento de Colombia como un Estado Social de Derecho, a la vez que se abre la puerta al mercado para la provisión de servicios como la salud y la educación. Respecto al Estado Social de Derecho, su rasgo característico es la inclinación hacia la igualdad, que en gran parte depende de la continua y deliberada intervención de las autoridades públicas para promover personas, grupos y sectores desfavorecidos (Múnera, 2007). Por lo tanto, el Estado es capaz de intervenir en la vida económica y social para que se dé el mismo valor a la libertad y a la igualdad (Múnera, 2007).

Históricamente el Estado Social de Derecho:

"se consolida en el momento en que las constituciones consagraron los derechos sociales, establecieron sistemas de cobertura social y prevención del riesgo, se aprobaron Pactos Internacionales de Derechos Económicos, Sociales y Culturales; se crearon las instituciones técnicas para intervenir en la planeación económica y se diseñaron procedimientos de participación política; finalmente se promovió el pluralismo como valor fundante entre las particularidades. Los Estados desde entonces se justificaron y legitimaron en la medida en que actuaban en favor de los grupos vulnerables y determinaron la inversión social como política pública diferente a las políticas de seguridad, control de fronteras y solución de conflictos privados, consideradas prioridades del Estado Liberal" (Gómez I, 2006, p. 78).

Por su parte, se implementa el neoliberalismo cuya definición como doctrina económica inició en 1947, cuando se postuló que "el mercado constituye el mejor instrumento, el más eficaz para la asignación de recursos y la satisfacción de necesidades. Un mecanismo autorregulador que 
conduciría al óptimo social y que por ello resultaría intrínsecamente superior" (Ezcurra, 1998, p. 14); planteándose políticas estatales como a) La promoción de un máximo de crecimiento económico (de libre mercado) como objetivo prioritario, b) Aumento de la tasa de ganancia del capital privado, c) Reducción de costos salariales, con una merma en el costo de la fuerza de trabajo y d) Contención del gasto público social (Ezcurra, 1998).

En la década de los 80’s con discretos ajustes a sus planteamientos originales, Inglaterra emprende su aplicación como modelo económico bajo la administración de Margaret Thatcher y la de Ronald Reagan en Estados Unidos. En la misma década llegó para quedarse en América Latina, donde incursiona con los ajustes estructurales encaminados al pago de la deuda de los países de la región y en la década siguiente se consolida como proyecto económico-político con regulaciones en materia económica, social y estatal (Ezcurra, 1998).

En cuanto a los ajustes en materia económica, el neoliberalismo implicó para Colombia el establecimiento de la apertura económica y libertad para la transnacionalización del capital financiero, siendo marco para las privatizaciones y las concesiones. En cuanto a la política social, significó la inclusión de la educación, la salud y los demás servicios concomitantes para satisfacer las necesidades básicas de la sociedad, dentro de las lógicas del mercado, es decir, oferta y demanda (Cruz, 2010).

En el neoliberalismo prima el individualismo y la competencia, la única justicia posible es que cada cual goce de lo que ha producido; sólo hay trabajo individual, no hay cabida para la distribución social, no existe la cooperación. Se trata de un Estado con la mínima intervención para favorecer la máxima libertad de los agentes que intervienen en la vida económica (Múnera, 2007).

En cuanto al gasto público, bajo el neoliberalismo el Estado focaliza y no oferta servicios 
sociales a todos los ciudadanos; sólo lo hace para quienes no tengan capacidad de pago siempre y cuando se considere que ellos tienen derecho a la asistencia, adicionalmente se entrega el manejo de los subsidios al sector privado.

Vale decir que los subsidios no garantizan al individuo la adquisición de las capacidades para incorporarse a las lógicas que impone la sociedad de mercado, muy al contrario agudizan la mentalidad de dependencia frente a la sociedad. El sostenimiento de los pobres con este método constituye una medida para facilitar la gobernabilidad, configurando una ciudadanía mendiga que descubre en sus posibilidades de acceso a los subsidios una forma de subsistencia y reproducción de sus escasas condiciones de vida materiales y espirituales, incluso las prácticas democráticas están supeditadas a la capacidad de los políticos de facilitar el acceso al subsidio (Cruz, 2010; Múnera, 2007).

Es por esto que las brechas sociales crecen producto de los modelos de alta competencia como el neoliberal, en el cual se hace necesaria una alta atención de los marginados o excluidos, pero a la vez es difusa la vocación del Estado para garantizar a los ciudadanos la igualdad de oportunidades con el fin de hacer efectivo el ejercicio de derechos económicos y sociales, sin los cuales la proclamación de la libertad civil y política, promulgada en la Constitución Política de 1991, se queda en simple retórica para la mayoría de la población.

Además de las ambigüedades del contrato social colombiano, se acude a otras conceptualizaciones en torno a los derechos y ciudadanía para abordar el cuestionamiento central de esta investigación. 


\section{DERECHOS Y CIUDADANÍA}

Thomas Marshall en su clásico ensayo Ciudadanía y Clase Social propone que la ciudadanía es fundamentalmente un estatus que se concede a los miembros de pleno derecho de una comunidad (Marshall, 1997). Para Marshall, la construcción de la ciudadanía se puede explicar a lo largo de tres siglos, con la progresiva incorporación de distintos derechos (Parola, 2004) por lo que define las tres partes que componen la ciudadanía plena de la siguiente manera:

- $\quad$ Ciudadanía civil: Establecida durante el siglo XVIII con el reconocimiento de los derechos necesarios para la libertad individual, a saber: la libertad de expresión, de pensamiento y religión, el derecho a la propiedad y a la justicia.

- Ciudadanía política: Consolidada durante el siglo XIX con la incorporación del derecho a participar en el ejercicio del poder político como miembro de un cuerpo investido de autoridad política o como elector de sus miembros, constituyendo el reconocimiento de los derechos políticos.

- Ciudadanía social: La incorporación de los derechos sociales se da en el siglo XX con la anexión del derecho a la seguridad, a un mínimo de bienestar económico, a compartir plenamente la herencia social y a vivir la vida conforme a los estándares de la sociedad.

Para Marshall la ciudadanía es una institución no local sino nacional por definición, que requiere un vínculo de unión y un sentimiento de pertenencia a la comunidad que se percibe como patrimonio común (Rivera \& Aragón, 2012). El desarrollo sucesivo, acumulativo, armónico e irreversible en la construcción de ciudadanía propuesto por este autor, tiene por los menos dos dificultades: la primera, es que se restringe a explicar lo sucedido en Inglaterra y no podría explicar 
lo acontecido en otros países, puesto que la lucha por los derechos, su reconocimiento y garantía es distinta en cada lugar (Rivera \& Aragón, 2012); en el caso de Inglaterra ese desarrollo fue la respuesta al conflicto social de la segunda posguerra en el que fue necesario un ajuste orgánico, institucional y solidario de la división del trabajo como elemento central para el desarrollo de la cuestión social, lo que a la vez requería de un Estado protector que regulara la función del trabajo y los derechos por éste generados (Alonso, 2007).

La segunda dificultad consiste en que de acuerdo con su descripción "bajo el universalismo de lo civil, lo político y lo social, quedan sepultadas consciente o inconscientemente todas las posibles diferencias, conflictos y dominaciones de clase, etnia, género o incluso nación" (Alonso, 2007, p. 115); lo cual implica que al reducir la ciudadanía solamente a los derechos civiles, políticos y sociales se niega otros grupos de derechos que progresivamente se han incorporado a la esfera de lo social, y es por eso que hoy se plantean muchos más tipos de ciudadanías como la industrial, la económica, la cultural, la cosmopolita, etc. (Rivera \& Aragón, 2012).

La ciudadanía es hoy entendida como una esfera multidimensional planteada a través de un proceso activo conquistado por las luchas colectivas y conflictos reivindicativos. Debe construirse en el mundo globalizado actual de manera asimétrica y flexible para que respete la identidad cultural y social de grupos étnicos, culturales, regionales o de género, de manera tal que estos actores reivindiquen su lugar en la sociedad global, "pero no perdiendo o renunciando a sus particularidades y diferencias históricas, sino considerándolas como referencias imprescindibles sobre las que tomar decisiones de las políticas públicas" (Alonso, 2007, p. 148). Si bien a todos los habitantes de un territorio les deben ser reconocidos sus derechos en igualdad de condiciones, se debe contemplar un margen para la particularidad étnica, cultural o regional que les otorga ciertas condiciones especiales. 


\section{EL ESTADO BENEFACTOR Y LOS DERECHOS}

Según Rosanvallon (1995) el Estado de Bienestar europeo que logró el reconocimiento de derechos sociales a los ciudadanos se construyó en parte sobre el sentido de solidaridad entre los ciudadanos, producido después de la segunda guerra mundial cuando muchos de ellos fueron llamados a morir por la libertad de la patria.

Bajo esta intención homogeneizadora durante la posguerra se mutualizaron los principales riesgos como la enfermedad, la desocupación, la jubilación, etc. y se instrumentalizó la protección bajo el esquema de seguros obligatorios, "el seguro actúa como una mano invisible de la solidaridad" (Rosanvallon, 1995); lo que determinó la consolidación del Estado Benefactor en Europa a mediados del siglo XX.

Sin embargo, el Estado de Bienestar y sus instituciones han ido desapareciendo desde finales del siglo XX; según Rosanvallon esto se debe fundamentalmente a dos razones: la primera, el denominado "desgarramiento del velo de la ignorancia" que es la incursión de la estadística, la demografía, la economía y la genética en la manera de cuantificar los riesgos, haciendo posible mediciones casi individuales que causan una ruptura en la idea de mutualización y un cambio en la concepción de lo justo y lo injusto. La segunda razón, una profunda transformación de la noción de lo social, en la cual ya no tiene un lugar central la protección de los riesgos sino la idea de vulnerabilidad o precariedad, entonces no se protege a todos por igual sino de acuerdo a su situación de precariedad, perdiendo sentido la protección colectiva (Rosanvallon, 1995).

En Norteamérica se desarrolló otro estilo de estado benefactor llamado por Rosanvallon

"sociedad de reparación generalizada". Profundamente liberal, en este modelo se desplaza el concepto de ciudadano por el de víctima y más que buscar la ampliación de los derechos sociales se 
pretende el fortalecimiento de los derechos civiles persiguiendo la redistribución sobre la base de la indemnización; en tanto un individuo es reconocido como víctima puede pretender una compensación. En palabras de Ronsanvallon "es ante la Corte Suprema y no en la lucha de clases donde se juega la cuestión de la lucha social en los Estados Unidos" (Rosanvallon, 1995, p. 66).

En contraposición al estado benefactor europeo, el norteamericano:

"tiende a poner cada vez más el acento sobre la idea de autonomía, el principio básico de la vida social pasa a ser dar a cada individuo, y a cada grupo, la posibilidad de vivir según los principios y con el modo de vida que desee. Los valores sociales centrales son la tolerancia mucho más que la solidaridad y la imparcialidad mucho más que la igualdad. La buena sociedad es la que permite la coexistencia pacífica de las diferencias; ya no la que asegura la inserción. El principio de ciudadanía ya no implica una exigencia de redistribución; se reduce a la confianza común en la ley civil organizadora de autonomía" (Rosanvallon, 1995, p. 64).

Se concluye que existen variados estilos de construir los estados de bienestar y cada uno de ellos define la forma de relación entre el Estado y el ciudadano, puesto que determina cuáles y en qué condiciones son reconocidos los derechos. Sin embargo, en América Latina nunca se desarrolló un Estado de Bienestar propiamente dicho; para Rosanvallon la dificultad de construcción de Estados de Bienestar al estilo europeo en los países subdesarrollados se debe al pobre desarrollo económico, junto a la poca generalización del trabajo asalariado, pero también y como razón primordial, se identifica el carácter superficial de su identidad colectiva, ya que no permite instituir obligaciones recíprocas (Rosanvallon, 1995). 


\section{EL TRABAJO, LOS DERECHOS Y LA CIUDADANÍA}

Posterior a la segunda guerra mundial, la idea de la existencia de unos derechos sociales ligados al trabajo, hace que el trabajo y sobre todo su regulación por el Estado se constituya en el centro de la cuestión social, definida históricamente como una programación política y ciudadana contra el riesgo y la incertidumbre. La centralidad del trabajo y su fuerte regulación por parte del Estado, produce la superación del miserabilismo obrero característico del siglo XIX. La mejor distribución del excedente económico permitió las condiciones para la participación política y social de los trabajadores, se trataba de la consolidación de la relación salarial fordista-keynesiana (Alonso, 2007).

En la edad de oro del Estado de Bienestar, se reconocían las limitaciones del mercado para el logro de los objetivos sociales de estabilidad y productividad, donde la cuestión social era resuelta mediante la construcción de organizaciones sociales fortalecidas y la consolidación de los objetivos y responsabilidades sociales de la empresa, se trataba de un capitalismo con una fuerte intervención pública que organizaba tanto la producción como el consumo a través de políticas públicas de gasto, redistribución y carga impositiva (Alonso, 2007).

El lugar central del trabajo, además de permitir la consolidación del Estado de Bienestar y el reconocimiento de los derechos sociales, vía reconocimiento de los derechos laborales, determinó una dinámica social en la que así como se superaba la vida de inestabilidad, marginalidad y pobreza típica del capitalismo previo al Estado de Bienestar, también se permitió la construcción de proyectos de vida en común, de cohesión social y solidaridad mecánica que permitieron el desarrollo de las sociedades europeas. El principal cambio fue el reconocimiento del trabajador-obrero como elemento fundamental en la redistribución de los frutos del crecimiento económico y la consolidación 
de las nuevas clases medias.

Ahora bien, el cambio a una economía globalizada y otras razones para la crisis del Estado de Bienestar, ha generado la flexibilización de la producción que ahora debe adaptarse a unos mercados imprevisibles y turbulentos, expuestos constantemente a la competencia internacional y la innovación tecnológica; se ha producido una transformación del capitalismo ordenado nacionalmente a un "capitalismo globalizado, fuertemente desregulado donde los mercados se han fragmentado y desestructurado, y donde las reglas del juego las ponen las nuevas empresas red de características transnacionales, las cuales se incrustan en el territorio sobrepasando la clásica idea del Estado-nación y estableciendo nuevas características de vinculación de lo local con lo global" (Alonso, 2007, p. 35).

Estas transformaciones han ocasionado cambios en la figura del trabajador, lo que genera modificaciones en la ciudadanía social, puesto que la condición de trabajador daba asiento a la ciudadanía social. La flexibilización de la producción ha ocasionado además, la flexibilización del trabajo y con ello la ruptura de los derechos sociales, fracturando las ideas de solidaridad y cohesión social.

Se ha reemplazado la idea del trabajador-obrero inserto en la sociedad y con goce legítimo de la herencia social por la de emprendedor, técnico, consultor, gurú o cualquier individuo exitoso que utiliza su capital humano (personal e intransferible) para potenciar el mercado. La flexibilización de la producción rompe cualquier idea colectiva de bienestar social, reivindica el éxito y reconocimiento individual, lo que representa:

"en la vida cotidiana de las personas una exigencia de oportuna empleabilidad, empresarialidad y adaptabilidad, exigiendo además una disponibilidad permanente para el 
cambio de empleo continuo, y con condiciones de trabajo cada vez más inestable y menos reguladas. Se pide un esfuerzo de formación, reciclaje, y prácticas a cuenta del buscado empleo, y se les anima a luchar contra la dificultad de encontrarlo, creando empresas propias o autoempleándose, porque...se ha impuesto la idea de que todos tenemos capital (económico, social, humano, simbólico, relacional, etc.) y somos empresarios, cuanto menos de nosotros mismos"(Alonso, 2007, p. 42)

La globalización y flexibilidad de la producción, también ha modificado el papel del Estado en la asignación de recursos y como garante de la satisfacción de necesidades. El Estado deja de tener fundamento en las políticas sociales de construcción de tejido social para tener centro en las políticas de rentabilidad tecnológica, financiera y monetaria (Alonso, 2007) incorporándolas como sinónimo de desarrollo, competitividad y modernización. En este panorama de Estado remercantilizador se vuelve cada vez más complicado la universalización de los servicios sociales y la estabilidad laboral, lo que conlleva a una fragmentación de la ciudadanía.

Con las nuevas exigencias del mercado, la intervención del Estado no sólo se ha vuelto selectiva a aquellos individuos o colectivos vulnerables, sino también estigmatizadora, ya que sólo la reciben los incapaces de insertarse en la producción, los ineficientes, los perezosos, los discapacitados.

Debido a que el trabajo llegó a ser el centro de la cuestión social y el vehículo para el reconocimiento de los derechos, su flexibilización no sólo significó el desmantelamiento de la ciudadanía laboral y social, sino el desprestigio de lo público y una herida de muerte a proyectos colectivos de progreso. 
La típica sociedad laboral, que sustentó del Estado de Bienestar clásico, se convirtió en un conjunto de culturas laborales y sub laborales inestables con biografías y trayectorias de inserción en el mundo laboral cada vez más diferentes. La flexibilización de las relaciones laborales si bien responde a las exigencias de un mundo globalizado y competitivo, no puede terminar por destruir las relaciones sociales, ni negar todas las reivindicaciones colectivas y de clase previas. Por lo tanto, el reto para el futuro es construir un Estado que si bien se encuentra flexibilizado en respuesta a las exigencias de la economía, no pierda la función de garantizar el reconocimiento de los derechos de sus trabajadores y ciudadanos.

\section{TRANSFORMACIONES SOCIALES}

En el centro del Estado de Bienestar se halla la idea de que el Estado tiene la obligación de garantizar a la población la protección contra los riesgos y ofrecerles una supervivencia con dignidad:

"Ese bienestar podía ser considerado como una forma de seguro colectivo contratado en conjunto que cubría individualmente a todos los miembros de la comunidad; esto es, una póliza de seguro que promete compensaciones proporcionales a las necesidades individuales, no al monto de los costos pagados por cada uno (...) En su forma más pura, supone la igualdad ante la necesidad, equilibrando las desigualdades existentes en cuanto a la capacidad de pago" (Bauman, 2011, p. 73).

El cambio en el modelo de producción vía economía globalizada, ha generado que las ganancias de las empresas se establezcan por el valor de las acciones y dividendos producidos, antes que por la cantidad de su producción; además es cada vez más fácil, rentable y costo efectiva la compra de mano de obra fuera del territorio nacional donde no existan exigencias sociales de los 
trabajadores y sea posible su reemplazo por máquinas o software.

En este panorama la contratación de mano de obra con garantías de seguridad social deja de ser un activo para transformarse en pasivo (Bauman, 2011), sumándole que ya no es necesario el esfuerzo por mantener una potencial mano de obra calificada y sana que permita renovar la existente, aspecto ineludible en el Estado de Bienestar y la sociedad salarial, ahora los trabajos se hacen flexibles y ocasionales. La asistencia del Estado perdió su importancia para la expansión y la seguridad del capital, puesto que con el interés de que los empresarios se quedaran en un territorio, era necesario reducir el costo de los servicios sociales y permitir trabajos precarios.

Estos cambios significaron el deterioro de los servicios sociales y el comienzo de la consideración de que sólo se prestan a los vulnerados y excluidos. Debido a que una persona promedio debe trabajar para satisfacer sus necesidades y las de su familia, el recurrir a la ayuda social pública es cuestión de pobres y fracasados, pero cuando la asistencia social se limita a este sector específico de la población se deteriora la calidad sin que resulte incómodo para la mayoría.

Estas transformaciones tienen un nivel más profundo de análisis que se ubica en el imaginario de la población, en lo "aceptado" como orden social, que si bien podría ubicarse dentro de un nivel netamente discursivo, legitima y permite diversos cambios y ajustes. Bauman (2011) propone el nombre de "instituciones panópticas" a esta categoría y las define como aquellas que moldean a los individuos para insertarse en la sociedad.

En la sociedad de producción, el mecanismo para dicha inserción tanto de hombres como de mujeres era el trabajo, en ese contexto las instituciones panópticas moldeaban a la gente hacia un comportamiento rutinario y monótono, limitando o eliminando por completo la posibilidad de elección; "el trabajo constituía el más elevado de los deberes y la condición ineludible para una vida 
honesta, garantía de la ley y el orden y solución al flagelo de la pobreza" (Bauman, 2011, p. 26). El trabajo era el principal determinante de la construcción de identidad y del lugar ocupado en la escala social.

Con la globalización se derrumba la sociedad de producción y nace la sociedad de consumo. El trabajo pierde su lugar como el principal agente socializador y es el consumo quien lo toma, convirtiendo a la competencia en el valor más importante entre hombres y mujeres. Al contrario de las anteriores instituciones panópticas, las de la sociedad del consumo prometen una ausencia de rutina y un estado de elección permanente, convirtiendo estas dos características en las virtudes esenciales y los requisitos indispensables para convertirse en un adecuado consumidor (Bauman, 2011).

Las identidades individuales construidas en estas sociedades son flexibles al igual que el mercado laboral, siendo el consumo y la competencia los factores determinantes a la hora de definir el lugar en la sociedad; "cuanto más sea la libertad de elección y cuanto más se la puede ejercer sin restricciones, será mayor el lugar que se ocupe en la escala social, mayor será el respeto público y la autoestima que pueda esperarse; más se acercará el consumidor al ideal de la buena vida" (Bauman, 2011, p. 54).

Esta nueva realidad borra la idea de igualdad y solidaridad que existía en el auge del Estado de Bienestar y acentúa las diferencias entre los individuos, vuelve a algunas ocupaciones o profesiones fascinantes e idílicas y a otras vergonzosas, expulsa del imaginario de felicidad y autorrealización al individuo que no puede elegir a quien vender su mano de obra sino que debe aceptar "cualquier trabajo"; tanto ese como el que recibe ayuda pública es un fracasado social. 


\title{
DE CERO A... ¿SIEMPRE? \\ NIÑEZ, INFANCIA Y ADOLESCENCIA
}

\author{
"No hay causa que merezca más alta prioridad que la \\ protección y el desarrollo del niño, de quien dependen la \\ supervivencia, la estabilidad, y el progreso de todas las \\ naciones y, de hecho de la civilización humana" \\ Plan de Acción de la Cumbre Mundial a favor de la Infancia, 30 \\ septiembre de 1990.
}

El Ilamado a la protección de la infancia y en concreto a los derechos de los niños, niñas y adolescentes, tiene un lugar destacado dentro de la política pública y en general en las discusiones sobre desarrollo social. En esta sección, se presentan diferentes vivencias de la infancia contadas desde el recuerdo de sus protagonistas; los cuatro relatos de personas con diversas edades y procedencias, permiten ver la materialización de los derechos en los menores de 18 años en Colombia.

Son historias pertenecientes a tiempos y lugares diferentes con diversas formas de infancia que a su vez exponen disímiles formas de ciudadanía. Irremediablemente estos relatos plantean la cuestión: ¿̇son los niños, niñas y adolescentes sujetos plenos de derechos?, ¿a partir de qué momento se inicia la construcción de ciudadanía?

De cero a siempre es la política pública de atención integral de la primera infancia (de 0 a 5 años de edad) vigente desde el año 2013. La justificación de esta política radica en que "la inversión en primera infancia es la más rentable que puede hacer una sociedad, debido a que tiene el mayor periodo de retorno y repercute en un menor gasto social a largo plazo" (Párraga, Abello, \& Rojas, 2013, p. 20). Esta política es resultado de la construcción colectiva entre los ministerios de Hacienda, Educación y Protección Social junto con el Instituto Colombiano de Bienestar Familiar-ICBF. 
Reúne planes, programas y proyectos dirigidos a promover y garantizar el desarrollo infantil de las niñas y los niños desde su gestación hasta cumplir seis años, a través de un trabajo unificado e intersectorial, desde la perspectiva de derechos y con un enfoque diferencial, articula y promueve el desarrollo de acciones para la atención integral que debe asegurarse a cada niña y niño, de acuerdo con su edad, contexto y condición (Párraga et al., 2013).

La intención de este capítulo no es hacer una revisión, crítica o estudio de impacto sobre la política de cero a siempre; su uso en el título obedece a la intención de mostrar que la inversión en protección de la infancia tiene resultados a lo largo de toda la vida, presentando cómo se viven diferentes trayectorias de infancia, cuyas diferencias ocurren por las condiciones personales y familiares para cada caso que significan una vivencia de ciudadanía desigual.

Se hace énfasis en que si bien la garantía de los derechos en la infancia es absolutamente necesaria en una sociedad desarrollada, el vehículo para conseguirla también debe incluir a la familia; los niños, niñas y adolescentes no están en el vacío, hacen parte de un contexto inmediato de cuyo bienestar depende el propio.

\section{TRABAJO INFANTIL}

Lo que más de duele es que me alejaron de mi hogar... es triste, a mí me dejaron con una señora que era la dueña de la casa de donde vivían mis papás, pero que desde los 7 años que lo alejen a uno de sus papás... me dejaron con ella que por bienestar, que por no sé qué, antes me habían dejado con mi abuelita... pero como uno es pequeño lo guían para donde quieran. Porque uno hoy en día piensa... y yo no haría eso, nunca lo hice con mis hijas... que mi papá decía que porque yo viviera mejor. 
En esa casa me tocaba hacer las labores de la casa, era muy duro me tocaba virutiar, ganarse uno [la comida] aunque iba a la escuela, pero siempre he sido muy malita para el estudio, casi no salgo de primero. Que yo que me acuerde, a mí me tocaba como pedirles permiso para ir a visitar a mi mamá, y a mis hermanos, yo casi no conviví con mi familia... a mí me tocaba como rogarles para ir a ver a mi mamá.

Yo no salía al parque, ni a jugar con otros niños porque como a mí me tenían allá, yo lo que recuerdo es que a veces cuando acababa me dejaban ver televisión, ese era el hobbie de uno. Yo llevo un resentimiento por lo que mis papás hicieron conmigo.

Margarita, 59 años.

Según el DANE para el año 2015, el 9.1\% de los menores entre 5 y 17 años eran niños trabajadores (DANE, 2016b); si bien esta cifra es alta, existe una sostenida tendencia hacia la disminución a lo largo de los últimos 15 años, tiempo desde el cual existen mediciones. Para el año 2001, la cifra era de 10.2\% (DANE, 2006), no hay datos oficiales del periodo en que Margarita empezó su vida laboral a los 7 años, hace aproximadamente 45 años (década de los 70’s). Sin embargo no es arriesgado pensar que la cifra era mucho mayor que el $10.2 \%$.

El trabajo infantil resulta problemático no sólo porque representa una violación a lo consagrado en la Convención de los Derechos de los Niños artículo $32^{9}$, sino porque está asociado a

\footnotetext{
${ }^{9}$ Artículo 32: 1. Los Estados Partes reconocen el derecho del niño a estar protegido contra la explotación económica y contra el desempeño de cualquier trabajo que pueda ser peligroso o entorpecer su educación, o que sea nocivo para su salud o para su desarrollo físico, mental, espiritual, moral o social. 2. Los Estados Partes adoptarán medidas legislativas, administrativas, sociales y educacionales para garantizar la aplicación del presente artículo. Con ese propósito y teniendo en cuenta las disposiciones pertinentes de otros instrumentos internacionales, los Estados Partes, en particular: a) Fijarán una edad o edades mínimas para trabajar; b) Dispondrán la reglamentación apropiada de los horarios y condiciones de
} 
negativas consecuencias para los menores. Por un lado la probabilidad de no recibir educación es el doble para aquellos niños que trabajan (DANE, 2016c), y por otro se ha establecido que los niños que trabajan frecuentemente son maltratados, abusados o abandonados por sus patrones, con quienes la mayoría de las veces establecen una relación de subordinación y dependencia. Como consecuencia aprenden patrones de socialización inadecuados, con deterioro de su autoestima y carencia de relaciones afectivas que les brinden un sentido de seguridad, acogimiento y protección. A la vez, estos niños y niñas tienden a desarrollar tendencias agresivas y actitudes de sometimiento, sin un proyecto de vida gratificante y de crecimiento (Batista, 2006).

Al no convivir en un medio amoroso, respetuoso y equitativo, los niños y niñas que trabajan no interiorizan valores protectores ni democráticos, y pueden tender a repetir en todos sus espacios de interacción los mismos patrones autoritarios aprendidos en la relación laboral. En general, es probable que tengan serias dificultades para desarrollar una personalidad autónoma e independiente (Batista, 2006).

Margarita recuerda dolorosamente la abrupta separación de su familia bajo la idea de un supuesto bienestar. Para sus padres significaba la provisión económica, pero para la niña la idea de bienestar era la posibilidad de vivir y crecer junto a sus padres y hermanos. Ahora siendo adulta busca la manera de resarcir ese "daño" con sus hijas, y al igual que muchos padres y madres anhela para la siguiente generación "que mis hijos no pasen por lo que yo he pasado"; en una suerte de reivindicación de la vida consigo mismo y con su familia que permite ver cómo en este caso la mejora

trabajo; c) Estipularán las penalidades u otras sanciones apropiadas para asegurar la aplicación efectiva del presente artículo. 
progresiva de las condiciones de vida no dependen de la presencia del Estado o de la implementación de la políticas pública, sino del esfuerzo personal y familiar para tener unas mejores condiciones.

\section{INFANCIA PLENA}

Bueno yo soy de Tunja, naci en Tunja, soy boyacense, bien boyacense, soy la última de tres hijos, mis padres son separados, mi papá se fue, cuando yo tenía como 4 años creo, no me acuerdo muy bien, recuerdo el día, pero no me acuerdo cuántos años tenía y ya... Después de la separación nos veíamos cada 8 días; con mi padre salíamos los domingos, a almorzar, comer helado e ir al cementerio.

Cuando estaba en primaria, el colegio tenía un convenio con la escuela [de música] y más o menos en tercero de primaria, siempre iba gente a decir: - ¿Quién quiere entrar a la escuela musical? Pero entonces nos hacían unos exámenes, que tocar música con lo que uno encontrara por ahí, que uno hiciera un instrumento con lo que uno encontrara por ahi; y mi mami me hizo platillos con las tapas de las ollas, así todas pintaditas, con maracas y a cantar; entonces pues así yo no sé cómo entré, pero entré a la escuela de música, eso fue cuando tenía 8 años y estuve como tres o cuatro años; cuando salí de la escuela de música volví a ser la representante del curso.

De niña recuerdo los viajes a Paipa, me daba como asco meterme en esas aguas calientes y con tanta gente, y yo sufría..., pero ya después uno ya se lo goza, ya se olvida y ya; también recuerdo un viaje en el que fuimos a ver estrellas fugaces con mis tíos y mis primos a Villa de Leiva... también viajes de olla, paseos de olla, si muchísimos con la familia. 
Marta, 31 años.

La representación frecuente de la infancia feliz consiste en la imagen de un niño o niña riendo, jugando o saltando; no cabe duda que el juego, el deporte y el arte son determinantes en el desarrollo de los menores de 18 años. Para algunos autores, el ocio y el juego hacen parte evolutiva del humano y consideran inclusive que "a través de los juegos y de su historia se lee no sólo el presente de las sociedades, sino el pasado mismo de los pueblos" (Unesco, 1980). Para otros, su importancia radica en las habilidades motrices, educativas, emocionales y sociales (Galves S \& Rodrígez L, 2005) que desarrollan y que finalmente repercuten en el proceso de aprendizaje y socialización para la vida posterior.

Un niño, niña o adolescente que tenga acceso a espacios de juego, arte, cultura y deporte tiene la posibilidad no sólo de desarrollar habilidades personales, sino también de encontrar otras alternativas de desarrollo futuro; por el contrario aquél que no tiene acceso a estos espacios le es coartada parte central de sus libertades y oportunidades.

Las historias de Margarita y Marta ponen en evidencia un factor determinante a la hora de garantizar ciudadanía plena en los menores de 18 años: la concepción acerca del menor como sujeto de derechos. Por un lado, está la idea de que los menores se encuentran en tránsito a ser sujetos plenos y por lo tanto son los adultos quienes toman decisiones por ellos y aún sobre sus deseos: Como uno es pequeño lo guían para donde quieran (Margarita); o por el contrario, que los menores tienen la oportunidad de expresar sus pensamientos y cumplir sus deseos: - Mami me hizo platillos con las tapas de las ollas, así todas pintaditas, con maracas y a cantar; entonces [...] entré a la escuela de música (Marta); estas concepciones determinan el lugar que ocupa el niño o niña en su núcleo básico y la organización que se adopte para la garantía de sus derechos. 


\section{INFANCIA RURAL}

Yo he sido criado con mi familia, mis papás y mis hermanos en la finca. De niño lo que hacía era obedecerles a mis papás en el trabajo de la finca, ayudarle a darle de comer a los animalitos. No jugaba mucho, no balón, o juegos, solamente a montar a caballo, era lo único.

Cuando no les hacíamos caso a mis papás, mi viejita nos trataba fuertemente, con una correa, la mayoría de las veces.

Aprendí a leer y escribir, en una escuela de la vereda solamente hice la primaria, pero en escuela de vereda, iba de 7 de la mañana a 2 de la tarde. Como mis viejitos eran de pocos recursos, entonces no hubo formas para seguir estudiando.

Trabajé un tiempo en la finca, allá pues aprendí el trabajo del campo, como decir: tirar macheta, sembrar yuca, plátano, todo así, y a cultivar. Siempre trabajaba en sociedad con mi papá, aunque tampoco eso era como un trabajo ya que quedaba como para beneficio de todos; nosotros éramos agradecidos con que nos dieran la posada, la alimentación y eso.

Cuando ya estuve de 14 años entonces ya salía a ganar jornal a otra parte y así empezar a tener mis moneditas por aparte, con eso compraba mi ropita, porque mis papis pues al mismo tiempo eran de pocos de recursos, entonces me empecé a vestir mejor.

Ya cuando ya tuve los 17 años, empecé a salir, como manejarme yo, solamente por mi cuenta, a no depender de ellos sino depender de mí mismo, entonces ya trabajaba era en otra finca ganándome un jornal para mí, y sin embargo ganaba mi platica y yo le pasaba a ellos también, les colaboraba.

Manuel, 51 años. 
En el contexto rural la infancia se vive en una escala de valores diferente a la urbana, el trabajo infantil no es entendido como un mecanismo maltratador sino como aporte al bienestar grupal familiar, donde se interioriza que todos deben contribuir en la medida de sus capacidades.

Según las estadísticas actuales el sector que más involucra niños trabajadores es el agrícola. Más allá de la estigmatización del sector y de los campesinos, es necesario considerar que la participación de los niños en las labores agrícolas se desarrolla en el marco de una economía familiar y solidaria que en general no significa para los niños maltrato o vulneración de sus derechos, aunque existen importantes excepciones.

Sin embargo, no porque el trabajo infantil suceda dentro de una economía familiar y no sea instrumento de maltrato, deja de ser problemático. Al contrastar las dos trayectorias que tienen como elemento común el trabajo infantil y la coincidencia en el tiempo, vale la pena mencionar que pese a que no ocurren en el mismo contexto geográfico, existen diferencias de género.

Si bien tanto para Margarita como para Manuel el trabajo no significó deserción escolar, si tuvo un significado diferente para cada uno. Para Margarita la opción de trabajo, que obedeció a la intención familiar de mejorar sus posibilidades económicas y aliviar la carga para el hogar, se dio como empleada doméstica, siendo éste oficio por muchos años la principal posibilidad laboral para las mujeres y en el cual el pago se daba en especie: comida, vivienda y estudio. Además, Margarita fue la única dentro del grupo familiar que corrió con esa suerte, en el momento en que sucedió tenía dos hermanos y ninguno de ellos fue separado de la familia. 
Contrario fue lo sucedido con Manuel, quien con la misma edad y permaneciendo junto a su familia, recibía retribución económica por sus labores, lo que significó tempranamente el logro de autonomía económica; en este caso el trabajo fue parte de su desarrollo personal.

Otro aspecto a resaltar en la historia de Manuel es que la definición de adolescencia como un periodo de transición entre la niñez y la adultez, es una construcción reciente en la historia moderna y no es compatible con todos los contextos. Establecer un tiempo para definir ¿quién soy y qué lugar ocupo en el mundo? (Erikson, 1933), no es una situación que se presente regularmente en la ruralidad ni en muchas comunidades nativas, en donde el paso entre la infancia y la adolescencia sucede por el desarrollo sexual o por la autonomía económica que puede lograrse inclusive desde los 17 años, como en el caso de Manuel.

Pasar de la infancia a la adultez abruptamente tiene consecuencias en términos de derechos

y deberes, puesto que pone en duda la obligatoriedad de reconocimiento y respeto por ese espacio de transitoriedad para la definición de un proyecto de vida bajo la protección de los padres, y obliga abruptamente a asumir las responsabilidades del mundo adulto sobre todo las relacionadas con la producción económica y la protección a las generaciones siguientes.

\section{ADOLESCENTE ENDEUDADO}

Yo puedo decir que a mí psicológicamente no me afectó la muerte de mi padre la los 3 años]... me gustaba la música pero por dedicarme al estudio, nunca me dedique a estudiar música, me gustaba el fútbol, pero también por dedicarme al estudio, no me dedique a ningún deporte, era buen estudiante. 
Entonces como yo había sacado un buen puntaje [en el ICFES], yo consulte por el ICETEX y tenía la posibilidad de un crédito que se llama "a largo plazo" donde mis codeudores eran mis padres, en ese casó mi mamá, y era crédito de aprobación automática, entonces yo tenía esa posibilidad... me voy a estudiar a Bogotá, a una universidad de renombre... yo muy disciplinadamente de lunes a viernes estudiaba fuerte, y los sábados me levantaba muy temprano y me iba al Restrepo y vendía mis camisetas.

Bueno uno queda súper endeudado, el ICETEX me presta 15 millones pero eso con intereses y todo queda en 50 millones, y ya para los últimos semestres como la matrícula quedaba como en 6 millones, tocó hacer un crédito con la misma universidad y termino debiéndole a la universidad como 20 millones y ya, más lo del ICETEX, entonces salgo súper endeudado, pero no importa me gradué!, y me graduó mi mamá súper feliz, mi familia también muy feliz!

En Colombia, la educación es reconocida como un "derecho y servicio público que tiene una función social" (Artículo 67 de la Constitución Política de Colombia), en el mismo artículo se indica que será obligatoria entre los 5 y los 15 años de edad y gratuita en las instituciones del Estado. Más allá del debate sobre si la educación superior también debería estar cobijada por la obligatoriedad y gratuidad, lo cierto hoy es que la cobertura de educación superior en el país (técnica, tecnológica y universitaria ${ }^{10}$ ) no llega al 50\%, lo que significa que existe un mérito personal o familiar en quienes logran acceder a ella.

\footnotetext{
10 Ley 30 de 1992. CAPÍTULO III Campos de acción y programas académicos. Artículo $7^{\circ}$ Los campos de acción de la Educación Superior son: El de la técnica, el de la ciencia, el de la tecnología, el de las humanidades, el del arte y el de la filosofía.
} 
En el caso particular de Francisco, aparentemente ese esfuerzo es reconocido por el Instituto Colombiano de Crédito Educativo y Estudios Técnicos en el Exterior-ICETEX, organismo gubernamental cuyo objeto definido en artículo 2 de la Ley 1002 de 2005 es:

"El fomento social de la educación superior, priorizando la población de bajos recursos económicos y aquella con mérito académico en todos los estratos a través de mecanismos financieros que hagan posible el acceso y la permanencia de las personas a la educación superior".

Sin embargo, resulta paradójico que el reconocimiento al mérito deje a las personas con una deuda superior al doble de lo realmente prestado, aun en casos en los que no se cubrió la totalidad del dinero invertido en educación. Si bien un título universitario significa mejores posibilidades laborales, su financiación es la evidencia de que no existe un derecho a la educación superior; los derechos no deben pasar por el mercado y de hacerlo en ninguna medida puede significar el endeudamiento del sujeto o su familia.

Según el ICETEX para el año 2015, se adjudicaron 103.648 nuevos créditos, lo que sumado a quienes ya "eran beneficiarios" representa un total de 652.783 (ICETEX, 2016) personas endeudadas para estudiar, cifra equivalente a 40 veces la cantidad de estudiantes de la Universidad Nacional de Colombia en todas sus sedes, tanto en pregrado como en posgrado (Universidad Nacional De Colombia, 2014).

Esta situación es tan dramática y compleja que ha ocasionado múltiples menciones en los medios de comunicación, donde se ha hecho un llamado a las instituciones reguladoras del sector y

Artículo $8^{\circ}$ Los programas de pregrado y de postgrado que ofrezcan las instituciones de Educación Superior, harán referencia a los campos de acción anteriormente señalados, de conformidad con sus propósitos de formación. 
al Congreso de la República para brindar soluciones a los "beneficiarios"(El Espectador, 2016; La República, 2013). A mediados de junio de este año se radicó en el Senado de la República un proyecto de Ley para que no les sean cobrados intereses sobre intereses a estos deudores (Oscuro, 2016).

Las historias de Margarita, Marta, Manuel y Francisco tienen en común la educación como espacio en el que se consolidan los derechos en la infancia. Sin embargo, para todos sucede de una forma desigual, exponiendo los diferentes tipos de ciudadanía que coexisten en Colombia y que se manifiestan desde la infancia. Con estas historias surgen tres grandes interrogantes en relación con la educación y la protección de la niñez:

- El primero, consiste en el rol de la escuela ante los menores trabajadores, ¿cuál es su responsabilidad ante esta situación? ¿Debería el sector educativo jugar un rol más protagónico en la garantía de los derechos de la niñez o su papel es meramente la formación académica?

- En segundo lugar, consolidar la escuela como interface entre la formación académicacientífica y espacio generador de habilidades para la vida a través de la recreación, arte y cultura ¿debería ser la generalidad en los centros formativos?

- Finalmente, en virtud de que el acceso a la educación superior depende fundamentalmente de un esfuerzo personal y de condiciones materiales individuales y familiares, significa que como sociedad estamos lejos de considerarla un derecho por lo que es un privilegio de pocos. 


\section{NIÑOS Y NIÑAS CIUDADANOS}

Aunque la frase "Todos nacemos libres e iguales en dignidad y derechos" de la Declaración Universal de los Derechos Humanos (1948) cobija a los niños, niñas y adolescentes, por muchos años se interpretó como referida exclusivamente al mundo de los adultos y pese a que en el Artículo 25 de la misma declaración es explícito que "La maternidad y la infancia tienen derecho a cuidados y asistencia especiales. Todos los niños, nacidos de matrimonio o fuera de matrimonio, tienen derecho a igual protección social", fue necesario que para entender a los niños, niñas y adolescentes como sujetos de derechos surgiera la Convención de los Derechos del Niño, proclamada por la Asamblea General de las Naciones Unidas el 20 de Noviembre de 1989 (ONU, 1989).

Esta Convención ha sido ratificada por la mayoría de los países, Colombia lo hizo a través de la Ley 12 de 1991 en los artículos 44 y 45 de la Constitución Política. La Convención de los Derechos del Niño es el tratado de Derechos Humanos más ampliamente ratificado a pesar de las diferencias éticas, políticas, culturales y religiosas; cobijando al 96\% de los niños del mundo (Durán, 2007).

El establecimiento de los derechos de los niños como capítulo aparte de los Derechos Humanos recuerda dos situaciones históricas de especial importancia. La primera que "los derechos" nacen como un asunto para regular las relaciones en el mundo de lo político (o público); según Arendt (2012) con la destrucción de las unidades organizadas que se basaban en el parentesco y el consecuente surgimiento de la polis, se le otorga a cada hombre una segunda vida: la política, conservando la privada al interior de su hogar (Arendt, 2012). Es en esa necesidad de ordenar las relaciones con otros en la esfera política, donde surge la idea de derechos como mecanismo regulador. Los derechos en el mundo privado de los niños, de las mujeres, de los ancianos, de las 
personas con discapacidad y la no violencia doméstica, son reivindicaciones recientes en la historia de la humanidad.

La segunda, es el entendimiento tardío de los niños y los adolescentes como actores sociales con características propias de desarrollo, necesidades, conflictos e intereses; superando su concepción como adultos incompletos. Una prueba indirecta es que la primera vez en la historia que se defendió a una niña por maltrato ante un tribunal (Nueva York, 1874), la defensa la hizo la Sociedad Americana para la Prevención de la Crueldad hacia los Animales, cuyo argumentó durante el juicio fue: "puesto que M.A. era parte del reino animal, merecía al menos, tanta protección como un perro común" (Durán, 2007).

La Convención otorga a los menores de 18 años la ciudadanía plena reconociéndoles:

- Derechos civiles y políticos: Derecho a la vida, la nacionalidad, la libertad de expresión, derecho a la asociación y reunión.

- Derechos económicos, sociales y culturales: Derechos a la salud, a un nivel de vida adecuado, a la educación, al juego y disfrute de la cultura, derecho al acceso libre a la información.

- Derechos colectivos y de los pueblos: Derechos a la identidad cultural.

Por lo tanto, los menores de 18 años no se encuentran en camino a hacerse ciudadanos, lo son desde el momento que nacen. Si bien el Estado es el principal responsable del cumplimiento de los Derechos Humanos para el caso de los niños, niñas y adolescentes se establece la corresponsabilidad de la familia y la sociedad (Durán, 2010); en parte porque el desarrollo de niños y niñas está fuertemente influenciado por las condiciones de vida familiar y por el contexto psicosocial que los rodea (Torrado P. \& Anzelín Z., 2009). Así mismo, se acuerda que en la ciudadanía de los menores de 18 años, tienen 
lugar privilegiado los derechos sociales relacionados con la supervivencia y el desarrollo, fundamentalmente la educación y la protección.

Los relatos expuestos muestran dos formas de infancia: con derechos y sin derechos. Aunque haya una diferencia temporal que podría hacer pensar ingenuamente que después de la adopción de la Convención de los Derechos de los niños, Colombia ha hecho realidad los derechos de los menores de 18 años, lo cierto es que existe suficiente evidencia de que aún hoy se viven diferentes tipos de infancia, que van desde la ciudadanía plena y garante de derechos hasta la exclusión y marginalización (Durán, 2007, 2010; Torrado P. \& Anzelín Z., 2009; Torrado p \& Bejarano N, 2009). Este hecho, permite concluir que el Estado colombiano ha sido incapaz de garantizar la ciudadanía plena de los menores de 18 años; demostrando la exclusión y contradicciones en nuestro contrato social.

Algunos expertos concluyen que la multiplicidad de formas de vivir la infancia en el contexto colombiano se explican en la

"realidad social y económica caracterizada por la pobreza, la exclusión y el impacto del conflicto armado; la ausencia de un marco orientador y regulador de las intervenciones dirigidas a la primera infancia colombiana; la existencia de múltiples planes y programas desarticulados; la visión sectorizada de las intervenciones; las insuficientes coberturas y baja calidad de los programas, y la ineficiencia de la gestión local"(Torrado P. \& Anzelín Z., 2009, p. 59). 
Con la intención de identificar cómo los menores de 18 años construyen sus nociones de derechos y ciudadanía, en este trabajo se establece que si bien las diferentes formas de infancia se sitúan en la exclusión social y las contradicciones del contrato social, se debe poner énfasis en el grupo familiar, no para culpabilizarlos de la no garantía de derechos, sino para hacer evidente que en los contextos familiares en donde los adultos tienen protección de sus derechos civiles, políticos, sociales, económicos y culturales los niños, niñas y adolescentes también los tienen; en concreto cuando los padres o madres de los niños tienen propiedad privada y/o trabajo y acceso a salud y educación, la probabilidad de que sus hijos tengan mayor garantía de los derechos y ciudadanía plena es mayor.

Se quiere mostrar que no existe una institucionalidad específica para la ciudadanía plena de los menores de 18 años, sino que la construcción de ésta depende las condiciones de sus padres; no se heredan solamente los genes, también la posibilidad de participación y pertenencia social, entendiéndola como ciudadanía.

¿Por qué es tan importante garantizar la ciudadanía plena en la infancia? No sólo es una cuestión de cumplimiento de pactos internacionales, existen razones biológicas y sociales para que merezca todo el esfuerzo. La razón biológica dice que es durante los primeros años cuando se desarrollan la mayoría de las conexiones cerebrales, las habilidades básicas del lenguaje, la motricidad, el pensamiento simbólico y las bases de las interacciones sociales, esto significa que es durante la infancia cuando se sientan las bases para que las capacidades, habilidades y potencialidades se desarrollen y multipliquen durante el resto de la vida (Párraga et al., 2013).

Las razones sociales evidencian que los niños que gozan de mejor salud, disfrutan de más juegos y pueden tener redes sociales más fortalecidas, presentan coeficientes de inteligencia más 
altos que el promedio y mejores destrezas de razonamiento; son niños que están dispuestos a aprender, que tienen índices casi nulos de deserción escolar, con mejor desempeño en la escuela y altas probabilidades de terminar su ciclo de desarrollo. Además en la edad adulta ostentan mejores ingresos, generan un mejor entorno para sus propios hijos, un ambiente físico más adecuado, mayor cohesión social, reducción de la pobreza y caída en la tasa de fertilidad, todo acompañado de menor violencia y criminalidad (Van der Gaag, 2003).

La garantía de ciudadanía plena en los menores de 18 años a través de la inversión en salud, educación, participación y cohesión social, es una herramienta efectiva para romper el círculo de la pobreza y disminuir las brechas de desigualdad (Párraga et al., 2013). 
¿SER PILO PAGA?

\title{
TRAYECTORIAS LABORALES
}

\author{
"Todas las definiciones de trabajo a las que podemos acceder \\ en español comienzan por contar que la palabra trabajo \\ procede del latín tripalium que no era precisamente un oficio \\ sino un tormento, tripaliare era ser sometido al castigo \\ consistente en uncir al castigado al yugo de tres palos unidos. \\ Se diría que en XX siglos, el trabajo no ha logrado desprenderse \\ del todo de esa interpretación inicial, nacida de la edad de \\ esclavos cuando trabajar y estar sometido eran términos \\ equivalentes. \\ William Ospina. \\ Tercer Seminario Internacional de Protección Social \\ Bogotá, septiembre 2012.
}

Ser pilo paga es el programa bandera de fomento a la educación superior del actual gobierno, consiste en el otorgamiento de créditos a estudiantes de estratos 1, 2 y 3 que obtengan altos puntajes en las pruebas SABER $11^{11}$. Para que estudien en Instituciones de Educación Superior acreditadas en alta calidad, el crédito contempla el pago de la matrícula y una cuota de sostenimiento, así como la vinculación a un programa de apoyo estudiantil al interior de la institución universitaria, con el objetivo de evitar la deserción. El crédito es condonable para aquellos que terminen sus estudios, quienes no lo hagan deben pagarlo de acuerdo con las correspondientes reglas.

En este apartado no se hablará sobre el programa, su uso en el título hace mención a la idea de la modernidad occidental de que el progreso sucede en gran medida por la cantidad de estudio que se pueda acumular a lo largo de la vida, representando mejores oportunidades económicas y la

\footnotetext{
11 Decreto 860 de 2010. Por el cual se reglamenta el Examen de Estado de Educación Media ICFES SABER 11. Artículo 1: Definición y objetivos. El Examen de Estado de la Educación Media, ICFES SABER $11^{\circ}$, que aplica el Instituto Colombiano para la Evaluación de la Educación (ICFES) es un instrumento estandarizado para la evaluación externa, que conjuntamente con los exámenes que se aplican en los grados $5^{\circ}, 9^{\circ}$ y al finalizar el pregrado, hace parte de los instrumentos que conforman el Sistema Nacional de Evaluación. Tiene por objetivos a) Comprobar el grado de desarrollo de las competencias de los estudiantes que están por finalizar el grado undécimo de la educación media. b) Proporcionar elementos al estudiante para la realización de su autoevaluación y el desarrollo de su proyecto de vida. c) Proporcionar a las instituciones educativas información pertinente sobre las competencias de los aspirantes a ingresar a programas de educación superior (....) entre otros.
} 
posibilidad de ascenso social; para lograr el éxito además se debe sumar una importante dosis de esfuerzo personal e inteligencia al momento de "aprovechar las oportunidades".

A través de los cinco relatos se mostraran igual número de trayectorias laborales que ponen en encrucijada la idea del éxito vía empeño y dedicación constante, revelando las distintas formas de construir derechos y ciudadanía, siempre ligadas a la dupla trabajo-mercado.

En la edad adulta, el trabajo y lo económico son centrales para el bienestar de los individuos, sobre todo porque en general el trabajo asegura el sustento y determina el nivel de protección contra los riesgos, así mismo el tipo de labor realizada define el lugar al que se puede aspirar dentro de la sociedad, siendo el trabajo el principal factor de ubicación social y evaluación individual (Bauman, 2011). Es tan evidente esta realidad que ante la pregunta: ¿Quién es usted?, la respuesta consiste en cuál es la profesión, ocupación u oficio y en qué lugar se desempeña.

La trayectoria laboral determina el itinerario de vida y es la medida más importante de éxito o fracaso de una persona; su principal fuente de confianza, inseguridad, satisfacción o autorreproche, orgullo o vergüenza (Bauman, 2011). El tipo de trabajo determina los derechos y obligaciones que se tengan y es a partir de este donde se pronostica la vida.

Aun así no es de libre elección, pues sucede en un contexto resultado del entramado social, político y económico que lo determina y regula. Es tan central su lugar en la sociedad que sus transformaciones han significado metamorfosis en la construcción de los derechos y la ciudadanía.

\begin{abstract}
LA FORMALIDAD
[Cuando termino la universidad, quedo súper endeudado, pero como tenía que hacer el rura ${ }^{12}$ ] entonces dije: -necesito que me paguen, no que le queden debiendo a uno (...) escojo
\end{abstract}

\footnotetext{
12 Rural es la manera como comúnmente los profesionales de la salud Ilaman al Servicio Social Obligatorio, que es el desempeño de una profesión con carácter social mediante el cual los egresados de los programas de medicina, odontología,
} 
Casabianca - Tolima, lo escojo porque era el que mejor pagaban porque era el más lejano y en zona roja; (...) Ileno de guerrilla y paramilitares. Mi sueldo eran 3 millones de pesos y tal cual me llegaba, tal cual se los pagaba al ICETEX. Hago mis 6 meses de rural y me quedo 6 meses más, ya tenía dos trabajos el de Casabianca y uno en Ibagué (...) decido volver a Bogotá después de dos años.

Yo llego a Bogotá, y todavía debía de ICETEX, tenía que ahorrar, entonces yo llego y contacto al doctor [profesor y amigo de la universidad], y él me vincula con un estudio de pacientes, al poco tiempo y gracias a su esposa entro a trabajar en el INVIMA duro dos años con ella y estando trabajando en el INVIMA había una funcionaria del Ministerio de Salud y me dice ¿qué por qué no te vas a trabajar al ministerio (salud)?, y me ofrece un grado de planta bajito, grado 10, entonces yo digo: - En el INVIMA era contratista tocaba hacer renovación de contrato cada año, y aquí (en el ministerio de salud) era de planta, entonces me vengo al Ministerio.

Ah bueno cuando yo estaba en el INVIMA, salió una convocatoria de la comisión nacional de servicio civil como para 80 mil cargos públicos, uno compraba el PIN en el banco y todo ese proceso, entonces yo me inscribí ahí y empecé el concurso.

Finalmente acepto la propuesta del ministerio, duro dos años hasta que clasifico en [en el concurso] y quedo de planta, de carrera; quedo de planta en un grado superior; en eso ya han pasado 7 años, ya estoy de planta en carrera administrativa.

enfermería y bacteriología, contribuyen a la solución de los problemas de salud de las poblaciones deprimidas urbanas o rurales o de difícil acceso a los servicios de salud en todo el territorio nacional. Es uno de los requisitos para obtener la autorización del ejercicio de estas profesiones. El Servicio Social Obligatorio se encuentra establecido en el artículo 33 de la Ley 1164 de 2007, y reglamentado por las Resoluciones 1058 de 2010 y 2358 de 2014. Es decir, es un año de trabajo profesional para obtener la autorización de ejercicio. 
Pagué mis deudas y empecé a ahorrar. Ah sí, entonces yo aprendí a manejar los recursos, si, mira no te imaginas entonces yo lo primero que dije ¿̇a quién hay que agradecerle por todo ese esfuerzo?, ia mi mamá!; terminé de pagar ICETEX, termine de pagar con la universidad, icomo en un tiempo de 6 años pague como 100 millones de pesos! Si, 50 del ICETEX y otros como 40 a la universidad y cuando ya terminé, logre el punto de equilibrio. [...] entonces ahorre y fuimos a Israel, estuvimos en Egipto, Jordania e Israel, fuimos los dos en el 2012, y entonces otra vez volví a quedar en cero; y ahí me puso juicioso en plan ahorro juicioso. Luego yo digo: -Necesito capacitarme para el tema que estoy manejando, y entonces me puse hacer un curso [del tema laboral] en España, allá estoy 6 meses y acá pido una licencia no remunerada y vacaciones.

Entonces empiezo a seguir ahorrando y quería ya pues un lugar donde vivir propio entonces ya hace 3 o 6 meses compre un apartamento, lo compre así chan con chan [en efectivo], entonces mira todo se ha dado, por eso te digo: es disciplina. La idea es lograr una estabilidad, lograr cumplir unos sueños, y la parte familiar creo que esta próxima, ahorita estoy solo, sí, más como tratar de cumplir esos últimos objetivos que me quedan y ya.

Ahora estoy aprendiendo a tocar guitarra, de hecho estoy aprendiendo aquí en el ministerio, en un curso que nos dan a los funcionarios.

La concepción que yo tengo de los valores humanos y los valores éticos que yo trato de aplicar acá en el ministerio, son de mi historia de vida, entonces todo ha sido una historia de auto exigencia, de auto esfuerzo, auto, auto.

Francisco, 35 años

La relación laboral formal es un ejemplo de la relación laboral del modelo fordista de producción que favoreció la edad de oro del Estado de Bienestar. Es sabido que durante el esplendor 
del Estado de Bienestar, el trabajo era entendido por todos los actores como un derecho y un deber, los empleadores aceptaban unos más que otros, que el Estado se encargara de la garantía de la calidad de vida de los trabajadores y sus familias: acceso a salud, educación, protección contra riesgos, vivienda y en general un buen nivel y calidad de vida mientras ellos garantizaban el acceso al trabajo y al salario. Esto era posible debido a que las ganancias de las empresas en ese modelo productivo dependían casi exclusivamente de la fuerza de trabajo, y por lo tanto era necesario contar con mano de obra calificada, sana y suficiente. Fueron épocas en que el Estado de Bienestar constituyó un círculo virtuoso con el capitalismo.

La construcción de esta relación laboral inició cuando la industrialización se convirtió en el motor del mundo occidental (finales del s. XIX y principios del s. XX), para ese momento las relaciones laborales estaban construidas sobre el trabajo precario de miles de trabajadores de las fábricas; y ante la necesidad de aumentar la industrialización se generó una fuerte disyuntiva entre perpetuar y profundizar la precariedad de los trabajadores o concederles un estatus que les permitiera, sino un ascenso en la clase social por lo menos unas mejores condiciones de vida.

Así se define el trabajo como la categoría para otorgar reconocimientos y derechos a los trabajadores y sus familias, por lo que se convierte en el vehículo principal para el reconocimiento de los derechos sociales en una sociedad fundamentalmente salarial; "a falta de ser propietario de bienes, el trabajador se vuelve propietario de derechos" (Castel, 2010, p. 314).

El éxito en el reconocimiento de derechos y garantías radicó en que las reivindicaciones eran colectivas. En los inicios de la industrialización las relaciones patrono-laborales fueron individualistas, pero a inicios del siglo XX se instauró la negociación colectiva y el respaldo institucional para el logro no sólo de buenas condiciones laborales sino también de derechos sociales, civiles y políticos. La 
consolidación de la sociedad salarial y con ello el reconocimiento del derecho al trabajo y la construcción de sólidos sistemas de protección social, explican el surgimiento y florecimiento de los Estados de Bienestar. Aunque en la sociedad salarial persisten las diferencias de clase social, el reconocimiento de derechos es homogéneo, "Ia mayoría de los miembros de la sociedad salarial, aunque ocupen posiciones diferentes en la jerarquía social, están unidos por los mismos derechos"(Castel, 2010, p. 316).

En cuanto a la ciudadanía, Thomas Marshall (1950) afirma que el trabajo aporta la última pieza: la ciudadanía social, que implica entre otras cosas derecho a la seguridad, al bienestar económico y a compartir la herencia social.

En la trayectoria de Francisco se evidencia cómo a través de la seguridad brindada mediante el trabajo formal se logra la garantía de los derechos:

- $\quad$ Pago de deudas, propiedad privada, ahorro: Derechos civiles.

- Ascenso laboral, estudios universitarios y de posgrado: Derechos sociales.

- Vacaciones, paseos, música: Derechos culturales.

Todo lo que le permite construir un proyecto de vida seguro y gozar de ciudadanía plena.

Sin embargo al profundizar en las nociones de este individuo acerca de derechos y ciudadanía, se observa que pese a gozar de una ciudadanía plena, en él prima la idea de esfuerzo personal y familiar por encima del acceso a un derecho: "historia de auto exigencia, de auto esfuerzo, auto, auto". El derecho a la educación es garantizado por el esfuerzo de su madre y el propio (mediante fabricación y venta de camisetas) donde la participación del Estado en este aspecto es el reconocimiento del esfuerzo personal mediante el otorgamiento de un crédito: “Entonces como yo había sacado un buen puntaje [en el ICFES], yo consulte por el ICETEX y tenía la posibilidad de un crédito". 
Al terminar su formación universitaria describe tener dos deudas que se concentra en pagar: una monetaria con el ICETEX y una "moral" con su madre que salda mediante un viaje. Después de honrar sus deudas disfruta para sí sus logros. ¿Acaso la educación no es un derecho que se garantiza mediante la corresponsabilidad entre la familia y el Estado? ¿Qué implicaciones tendrá esta concepción para las generaciones futuras de éste individuo? Los derechos son condiciones inalienables de los seres humanos y el acceso a ellos no debe generar culpas o pagos.

En relación con la inserción y trayectoria laboral, aparece nuevamente la idea de lucha personal, "pasé las fases del concurso y entré en una categoría más alta"; y aunque para él no sea evidente surge como determinante el capital social-relacional al momento de tener posibilidades en el mundo laboral, ya que son sus amigos quienes le brindan oportunidades en este sentido. El capital relacional se convierte en un elemento que potencia el valor de su fuerza y capacidad de trabajo, y nutre las posibilidades de desarrollo profesional u ocupacional.

No existen esfuerzos o logros enteramente individuales; factores como el acceso a la educación, la salud, la red familiar y la red social construyen oportunidades y permiten el desarrollo personal.

\section{LA PROPIEDAD PRIVADA Y LA RENTA}

Perdí el año en el colegio [séptimo grado] y me pasaron a otro, en el que me metieron en el taller de fundición, resulté como trabajador ahí en el colegio, no iba a clase por quedarme en el taller y volví y me tire el año. Entonces, para que mis papás no perdieran más plata [en el estudio] decidí no estudiar más, yo mismo me salí, me puse a trabajar de día y busqué colegio nocturno, hice 8, 9, 10 y 11 grado. 
Como mi papá había comprado una tarjetera, en esa época tener una tarjetera era una herramienta de trabajo para hacer plata, es una máquina manual de artes gráficas; él me enseñó a usarla y empecé a hacer por ahí mis trabajitos, alguien me decía necesito unas tarjetas y yo buscaba cómo hacérselas y las hacía (...) yo era empírico en eso, yo no era técnico; le hice unas tarjetas a un cliente y le gustaron y fue mi primer cliente (...) , le estoy hablando de hace 30 años y actualmente trabajo con ellos.

Llegó un tiempo en el que alcancé a comprar como cuatro o cinco tarjeteras, hacía mil, dos mil, diez mil tarjetas una por una y con la mano; tenía empleados, que eran chinos del barrio y yo les pagaba por lo que hicieran. En ese entonces yo no sabía qué era constituir una empresa, yo no sabía ni elaborar una factura para cobrar, nada de eso, yo entregaba y me pagaban.

La empresa de los judíos [los primeros clientes] creció mucho y terminé trabajando como con unas 10 empresas de judíos que son a los que le debo lo que yo tengo porque el pago con ellos es muy bueno, yo llegaba con el trabajo y me venía con mi plata.

A los 16 años, graduado del colegio, ya tenía cuatro máquinas tarjeteras y cuatro empleados, entonces decidí comprar una guillotina, en esa época iera lo máximoi Y tiempo después una máquina litográfica, yo mismo hacía mis artes, mis planchas; ahí si ya yo manejaba a nivel de empresa, ya hice mis facturas, ya entregaba remisionado, ya después facturaba, ya daba crédito de treinta días porque ya tenía cartera, pero todavía no estaba legalizada porque en ese tiempo no exigían tanto la cámara de comercio, ni el RUT, como ahora. Nunca pensé en estudiar, me iba muy bien en el negocio.

Luego se me dio por casarme y comprar un bus, como tenía chequera a los 17 años, con eso compré el bus; luego lo vendí y me metí en el transporte especial, entonces compré 
una camionetica para llevar empleados de las empresas, luego compré otra camioneta que manejaba un muchacho y luego un bus de turismo; con los empleados siempre era informal, sin prestaciones ni nada, yo le pagaba por lo que hacían.

Luego compré una casa en la que tenía el taller, trabajamos muy duro, nos fue muy bien también (...) luego la vendí y compré una casa grande de tres pisos, en el primer piso adecue garaje para guardar los carros y trabajar, tenía taller y garaje, en el segundo piso fue mi vivienda y por variar en el tercer piso monté el taller de confecciones, tuve como unas 6, 8 personas en confección (...) por razones de seguridad el cliente de la confección se tuvo que ir del país, entonces la confección se acabó y vendí las máquinas, pero me fue muy bien, fueron no sé yo creo que por ahí un año con eso, pero súper bien, súper bien, claro eso fue algo pasajero.

En esa casa una vez llegaron por mi [intento de secuestro], me tocó venderla.

Siempre a mí me ha ido muy bien para que me voy a quejar, siempre le he dado gracias a Dios por eso (...) en mi época de juventud [trabajé mucho] por eso hoy en día, no me arrepiento de estar descansando porque cuando le di, le di, le di muy duro.

Luego de eso, compré mi apartamento y una casa vieja que demolí e hice una bodega, que dividí en cuatro, entonces tenía tres bodegas en arriendo y mi espacio; luego compré otra bodega, que dividí en dos; y ya compre máquinas más sofisticadas, compre máquinas de formato grande y ya; ya le prestaba servicio a otros colegas, me iba muy bien y así seguí trabajando, dedicado. Todos los negocios los hice con letras [de cambio], no en bancos.

Después resulte no con los buses, sino comprando una empresa de turismo porque yo dije: -El negocio no está en los carros, el negocio está es en la empresa (...) pero por un problema me sali del negocio. 
Tenía mis dos bodegas rentando y mi empresa produciendo, fue cuando hice un negocio, y compré un terreno, lo mande cubrir, lo pinté, lo reconstruí, lo puse muy bonito y lo tengo rentando también, con un lavadero de carros.

Así he invertido en finca raíz y me he venido sosteniendo, a las hijas pues ya hay una profesional, la otra también ya está a punto de ser profesional, ya el negocio de las artes gráficas lo pase a segundo plano, ya no me mato por licitar, yo ya no peleo, si es rentable lo hago, sino que lo haga otro, así de sencillo y tengo mis bodegas rentando.

Los últimos empleados que tuve, los tuve por una agencia de empleos con todas las de la ley. Yo le pago a la agencia un porcentaje y ellos le dan su prima, sus vacaciones, su sueldo, su liquidación y no me obligan a cumplir contrato, el día que el empleado se quería ir o que yo quiera salir de él, sólo pasa a la oficina a que lo liquiden y no tengo ningún compromiso con la gente.

José, 50 años.

Las premisas: a) si se quiere conseguir lo necesario para vivir y ser feliz, hay que hacer algo que los demás consideren valioso y digno de pago, b) nada es gratis, c) está mal, es necio y moralmente dañino conformarse con lo ya conseguido y quedarse con menos en lugar de buscar más, d) es absurdo e irracional dejar de esforzarse después de haber alcanzado la satisfacción, e) no es decoroso descansar, salvo para reunir fuerzas y seguir trabajando; sustentan la ética del trabajo (Bauman, 2011), que si bien fue efectiva al momento de convencer a generaciones de campesinos para dedicarse a las labores en la incipiente industria europea e intercambiar su trabajo por unas monedas, niega la importancia del ocio en el desarrollo humano y el lugar que tienen los colectivos 
en la construcción de la vida moderna; de la misma manera ignora que pese a estar trabajando se viva en la pobreza, precariedad y exclusión.

La historia de José enfatiza en un factor trascendente a la hora de entender la construcción de los derechos y ciudadanía: la estrecha relación que tienen éstos conceptos con la propiedad privada, puesto que fue el reconocimiento de los derechos civiles y políticos (siglos XVIII y XIX) a los varones con propiedad el primer paso en el camino de la construcción de la ciudadanía; en palabras de Marshall la consolidación de la ciudadanía civil, fundamentalmente el derecho a la propiedad privada y la justicia.

Si bien en la declaración de los Derechos del Hombre y del Ciudadano se promulgaba que "todos somos libres e iguales", la verdad es que para aquella época (siglos XVIII y XIX) el reconocimiento de derechos se otorgaba a quienes tenían propiedad, y en ese sentido ser propietario era ser ciudadano. Según Castel (2010) "en los comienzos de la modernidad, la propiedad no es solamente un valor burgués, un privilegio de clase, es la condición de posibilidad de la ciudadanía"(Castel, 2010, p. 311).

El papel protagónico de la propiedad en la garantía de derechos no finaliza en el siglo XX con la inclusión de los derechos sociales en la ciudadanía, por el contrario, como lo muestra el caso de José, actualmente la propiedad privada continúa siendo un vehículo para garantizar los derechos sociales, económicos y culturales. El dinero generado permite acceder a los derechos vía mercado, la propiedad privada posibilita plantear un proyecto de vida individual y familiar bajo la seguridad económica, dicha garantía requiere también de una gran dosis de esfuerzo personal y competencia. José narra su trayectoria haciendo énfasis en el esfuerzo personal, constante y solitario lo que si bien justifica las premisas de la ética del trabajo, desconoce a quienes contribuyeron en la fabricación de sus activos, como su padre quien le proporcionó el primer medio de producción 
(máquina tarjetera) y el entrenamiento para su usufructo; o la contribución de los clientes y "empleados" quienes vendieron su fuerza de trabajo mediante una relación flexible y precaria en la que nunca tuvieron reconocimiento de los derechos sociales derivados de su labor, ni acceso a la propiedad de los medios de producción.

Otro elemento favorecedor para que esta trayectoria fuera exitosa fue el contexto económico colombiano, en esa época surgieron y se consolidaron nuevas actividades económicas, en especial la industria manufacturera, el sector del transporte, financiero, comunicaciones y servicios públicos modernos (electricidad, gas y agua). En conjunto estas actividades pasaron de representar el $23 \%$ de la actividad económica en la segunda mitad de los años cuarenta, a cerca del 40\% a comienzos de la década del ochenta (Ocampo, 1987). El crecimiento de estos sectores se acompañó de una fuerte reducción de la participación del sector agropecuario en la economía nacional, a la vez que significó el aumento de la participación de cada uno en el Producto Interno Bruto, pasando del 8\% en 1945 a más del 18\% entre 1980 y 1984 (Ocampo, 1987).

Además existía un precario control del gobierno frente a la formalización de las empresas y sus trabajadores, debido en parte a que los esfuerzos se encontraban concentrados en la política de vivienda popular y el fomento del crecimiento de la industria y la agricultura (Ocampo, 1987). Por todo lo anterior, se explica cómo José crece su negocio sin formalizarlo (sin tributación), con trabajadores vinculados informalmente. Sólo años después cuando el tamaño de su empresa aumenta y el control del Estado se fortalece, formaliza su negocio pero continúa sin asumir la carga prestacional de sus empleados, obligación que evade mediante la tercerización.

No se puede terminar el análisis de esta historia sin mencionar que la desescolarización y en general la escasa formación académica se tolera socialmente en las personas que logran superación 
económica, lo que significa que la verdadera medición de éxito social lo determina la cantidad de dinero acumulado y no la formación o producción intelectual.

\section{EL DESTIERRO}

Mención especial requiere las trayectorias de quienes han sido víctimas del conflicto armado interno, sus historias hacen entrar en crisis las teorías modernas que pretenden explicar la forma en que se interceptan los derechos, la ciudadanía, el estado y la libertad. En estos relatos no hay propiedad privada que garantice libertades, no vale esfuerzo personal, honestidad, trabajo, no hay familia que proteja y resguarde y sobre todo no hay Estado capaz de contener el infortunio.

En el campo solamente dedicado al trabajo; cuando ya estuve de 14 años, entonces ya salía a ganar jornal a otra parte y así empezar a tener mis moneditas por aparte (...) y cuando ya tuve los 17 años, empecé a salir a manejarme solamente mi cuenta, a no depender

de ellos sino depender de mí mismo, entonces ya trabajaba en otra finca ganándome un jornal para mí, sin embargo ganaba mi platica, y yo le pasaba a ellos también.

Tenía 20 años cuando me abrí del lado de mis papás, me fui para otro pueblo más adelante del Ilano, Paz de Ariporo, porque era mejor vida. En el Llano es así, en ese entonces había mucho trabajo y no había tantas máquinas para trabajar, entonces uno se iba para los parques en el Yopal, en el Llano y entonces allá llegaban todos los dueños de finca a contratarlo a uno, le preguntaban a uno que si iba a trabajar y uno decía que sí, y listo.

En eso llegué a una finca grandísima a talar potrero, en eso conocía la hija del patrón, empecé a enamorarla cuando tenía 14 añitos y a los 15 años me casé y seguí trabajando en la finca de mi suegro, pero ya entonces él acostumbraba a cada hijo que se casaba le daba un 
lotecito de tierra, entonces ya nos dio un lote de tierra, luego vendí ese pedacito de tierra y compré una finca más grande.

Duramos 7 años viviendo ahí y luego fue cuando ella se puso a ser amable con un miliciano de la guerrilla y como era tan jovencitica, pensó que conseguir otro hombre era normal, entonces ella pues quiso correrme a mí para quedarse con un miliciano en la guerrilla.

Un día yo estaba trabajando en la finca, cuando me llamaron dos tipos con pistolas y me dieron tres días de plazo para irme, me tuve que ir sin nada; yo tenía dos hijos: la niña tenía seis años y el niño tenía siete años y medio. Esa fue la primer desterrada que tuve. Yo tenía en la finca 15 vacas del ordeñe, unas 300 gallinas, marranos, estaba muy bien parado, si estaba bien parado.

Volví a la casa de mis padres, pero entonces eso es muy duro, yo no fui capaz; entonces dije: pues un trabajo como más fácil, un trabajo donde vea gente todos los días y fue cuando empecé a hacer el pan.

Poco a poco fui aprendiendo, entonces yo le cambiaba el sabor, el color, la anchura y le ponía yo mismo el nombre a cada pan, que yo hacía, hacíamos unos 20 o 25 clases de pan; ya cuando cogió fuercecita la mande a matricular, la puse la panadería el Buen Amigo. Vendía mucho, tenía mis buenos clientes, la guerrilla me compraba 2000 panes diarios y empecé a comprar otra vez mis cositas.

Luego se me dio por cortar pelo los domingos, [para aprender] yo me iba de peluquería en peluquería y miraba cómo cortaban el pelo (...) y empecé a trasquilar, la guerrilla me mandaba su gente los domingos para que yo les cortara el pelo. 
Como en el 2000 o 2001, cuando se militarizaron todos los pueblos, y al lado de eso llegaron los paracos, entonces a algunos nos mandaban llamar con un soldado: -Que nos necesitaban en tal parte, y cuando uno iba allá, eran los paracos, mataron bastante gente.

Me mandaron llamar y dijeron que yo era guerrillero, yo les decía: -Yo si vendo a la guerrilla, le vendo al que llegue, pero no soy guerrillero, todos somos criados y nacidos en ese pueblo y nunca hemos sido guerrilleros, guerrilla si hay les dije, pero nosotros no somos guerrilleros.

A mi me echaron al agua los que me tenían envidia porque yo progresaba en mi negocio y entonces la gente del pueblo, y los otros dueños de negocios son muy envidiosos de unos con los otros y como a mí me iba bien y me compraban bastante, ellos dirían: - Claro toca sacarlo de aquí, para que ellos se pudieran quedar con sus negocios.

Me tuvieron 15 días, la mayoría amarrado, encerrado y entonces me iban a matar; gracias a las oraciones de mi familia y amigos me dejaron libre, y me dieron 36 horas para desocupar ese pueblo, me fui para Sogamoso donde el papá de mi empleada, que también la desterraron; gracias a un amigo del papá de ella conseguí trabajo acá en la ciudad [Bogotá] y entonces fue cuando me vine aqui para la ciudad. Perdí todo otra vez.

El amigo tenía un taller de máquinas, de reparación de máquinas, entonces empecé así, pero como no sabía me colocaba era a limpiar máquinas, limpiar tornillos así, (...) duré aproximadamente unos 7 años, trabajando en una empresita ahí, pero apenas para el diario, para el arriendo, a veces ni para el diario, eso de ser empleado no hace uno nada. Fue cuando me mandaron de operario para donde estoy trabajando ahora, duré 5 años operando una máquina y ya luego los ingenieros y los maestros me cogieron confianza y ahora me dejaron el casino, un restaurante en la obra. Manuel, 51 años 
La primera conclusión de este relato es que aunque se cuente con medios de protección como la familia, la propiedad y el trabajo, es imprescindible la garantía de seguridad y respeto por la vida otorgada por el Estado, siendo esta protección el mínimo sobre el cual se pueden dar diferentes trayectorias.

En el contexto rural se observa que los principales factores determinantes a la hora de garantizar los derechos son: la familia y la propiedad de la tierra. En relación con la familia, en este contexto se asignan responsabilidades en las labores agrícolas desde temprana edad, cada miembro aporta a la economía mediante el trabajo. Respecto a la propiedad de la tierra, ésta constituye el principal medio de producción y fuente de seguridad e inclusive se puede acceder a ella vía matrimonio.

Cuando el campesino no tiene acceso a la propiedad de la tierra vende su fuerza de trabajo, el valor de la misma no aumenta con el nivel educativo ni con el capital social-relacional, sino que vale estrictamente su capacidad física y se transa en un contexto de informalidad, en el cual jamás ha existido reconocimiento de derechos asociados al trabajo.

Es justamente este hecho el que explica en gran parte, el precario nivel de protección social que caracteriza a los campesinos colombianos. Los sistemas de protección social fueron diseñados para el mercado laboral formal, sin tomar en consideración las particularidades de las poblaciones rurales y los riesgos a los que se enfrentan (CEPAL, 2015).

Otro factor que empeora la situación de protección en las zonas rurales, es la falta de información y análisis acerca de quiénes son los habitantes rurales, cómo están conformadas sus familias, cuáles son las actividades productivas a las que se dedican y cuál es la dinámica particular de los mercados en los que se insertan (CEPAL, 2015). El resultado es la alta proporción de familias 
campesinas desprovistas de protección de sus ingresos y de protección para contingencias como la enfermedad, la discapacidad o la muerte.

Un informe preparado por la CEPAL y el equipo técnico de la Misión para la Transformación del Campo (2015), analiza la situación de protección social en la zona rural mediante las siguientes categorías:

- Protección contributiva: Hogares donde algún miembro cotiza al sistema de seguridad social.

- Protección no contributiva: Hogares donde no hay protección contributiva y reciben subsidios del Estado, incluido la afiliación al sistema de seguridad social mediante régimen subsidiado.

- Protección mixta: Hogares con protección contributiva y no contributiva.

- $\quad$ Sin protección: Hogares sin ninguna protección.

Allí se revelan cifras contundentes al momento de identificar la brecha urbano-rural: el 9\% de la población rural tiene protección contributiva en contraste con el 41,3\% de la población urbana. En cuanto a la protección no contributiva las proporciones son: 33,4\% rural y 12,5\% urbana; sin protección se encuentra el 53\% de la población rural y el 37\% de la población urbana; en cambio la protección mixta es de proporciones similares entre el campo y la ciudad con un 3\% y $4 \%$ respectivamente.

Esto evidencia la precaria cobertura de la protección contributiva y el crecimiento de la protección de la población rural a expensas de programas de asistencialismo, donde tiene un lugar protagónico el programa Familias en Acción y Más Familias en Acción, también se encuentran programas de adulto mayor, programas de generación de ingresos e inclusión productiva (Ingresos para la Prosperidad y Mujeres en Acción del Departamento para la Prosperidad Social) y la estrategia 
de acompañamiento para la superación de la pobreza extrema - UNIDOS - de la Agencia Nacional para la Superación de Pobreza Extrema (ANSPE).

Sin embargo, al analizar en conjunto este tipo de programas sobresale el hecho de que tienen coberturas muy pequeñas y aquellos con coberturas más amplias llegan a la población con apoyos mínimos para las inmensas necesidades de tales zonas. A pesar de los esfuerzos presupuestales y de diseño que implican estos planes y programas, resultan insuficientes en cobertura, pertinencia y sostenibilidad; adicionalmente por su limitada capacidad resolutiva y a escala los resultados obtenidos en el corto plazo se desvanecen en el tiempo (CEPAL, 2015).

Para que políticas y programas de este tipo tengan mayor impacto, los expertos recomiendan que se orienten hacia una doble inclusión: tanto social como productiva, articulada al sistema de protección social, ya que cualquier esfuerzo aislado en lo social sería insuficiente sin las inversiones requeridas para el fortalecimiento productivo de la actividad agropecuaria y de todas aquellas que se desarrollan en las zonas rurales (CEPAL, 2015) incluyendo la protección de la propiedad de la tierra.

La situación de precariedad, exclusión social e incipientes redes de protección social de la población rural, se empeora aún más cuando es principalmente en esos territorios donde se ha desarrollado el largo y complejo conflicto armado colombiano, que encuentra entre sus principales generadores a la propiedad de la tierra.

La historia de Manuel pese a ser una historia de esfuerzo, trabajo, sacrificio, violencia y exclusión, también incluye como protagonistas la perseverancia, la búsqueda de oportunidades y la resiliencia, siendo ausente la competencia, la individualidad y sobre todo el reclamo del derecho. Ante las constantes dificultades y violaciones de sus derechos, su respuesta es empezar de nuevo sin acudir a una institucionalidad que le garantice los mínimos de los que se habla en la Declaración Universal de los Derechos del Hombre y la Constitución Política de Colombia. Pareciera que la vida 
en condiciones difíciles enseña a sobrepasar las dificultades y continuar, no dejando tiempo para reclamar ante la sociedad y en particular al Estado la garantía de los derechos, en un contexto en que lo único que se tiene es el convencimiento del valor propio.

\section{LA INFORMALIDAD}

Después de que él se fue [el esposo] volví a coger mi oficio [después de 20 años de casada, no tenía propiedad ni ingresos fijos y era la responsable de sus dos hijas], mi hermana me dijo: - Camine y me ayuda allí donde la señora Amanda, y volví a coger mi oficio [empleada doméstica], hace ya 18 años, ahí ya empezó la cadena, ella fue y le ayudó a la señora Amanda, entonces ella tiene más hermanas, y un día una de las hermanas dijo: -Yo necesito una [mujer] para que me ayude a hacer el aseo, entonces ahí empezamos a trabajar y buscábamos familias para trabajar, a mí siempre alguien me recomienda para trabajar. Con esa señora llevo 18 años trabajando.

A mí me agrada, sé que me pagan con cariño, mi Dios me multiplica mi sueldo, yo me siento contenta de dejarle limpio, sé que me pagan para alzar el reguero, aunque hay gente muy desconsiderada.

Cobro por días, no todos me pagan lo mismo, hay personas que me pagan mensual y hay otros lugares donde trabajo sólo cada 15 días, esa es la plata que dejo para desorganizarme, tengo dos suelditos, [de los trabajos semanales y el de los trabajos quincenales]. Yo tengo deudas en Codensa, un día me llamaron y me hicieron un préstamo y como vi mal a mi hermano, entonces saqué y le preste 5 millones a él y yo cogí 3 para desorganizarme, [crédito de 9 millones a 60 meses], es que uno a veces no sabe administrar, 
entonces voy pagando, yo organizó esos dos sueldos para pagar mis tarjetas. Ahora estoy trabajando para pagar las deudas.

Para salud tengo el Sisben, pero ahora me atienden en Salud Capital [régimen subsidiado] se ha vuelto tan malo para uno pedir una cita, pero ya me hicieron la operación de la vena, y mis chequeos cada dos meses. En una época que estuve mala, y usé un médico particular, pero ya no tengo queja.

[A las personas de la Alcaldía] yo les dije una mentira, es que me siento cansada, no tengo una pensión, nunca cotice, entonces yo dije allá una mentira, fueron y me hicieron la encuesta, dije que yo vivía arrimada con mis hermanos [vive en la casa paterna] en una piecita allá feita, que yo casi ni cocinaba y como yo trabajo por días, pues que era difícil, entonces me dieron una ayuda, [\$120.000 mensuales] ya llevo 4 meses, no sé hasta cuándo lo tendré.

Mis últimas vacaciones [no pagadas] fue hace como 10 años cuando fui a la costa a conocer a mi nieto, que acababa de nacer, cuadré unos días en los lugares en los que trabajaba y me fui, no me pude demorar mucho.

Margarita, 59 años

El sector servicios fue el gran receptor de las mujeres al inicio de su incorporación en el mundo laboral bajo promesa de ofrecer una mayor posibilidad de conciliación entre la vida familiar y la vida laboral (Todaro \& Yáñez, 2004); este hecho también obedece a la estricta división sexual del trabajo. Dentro del sector servicios se encuentra el trabajo doméstico, con una sobrerrepresentación femenina (95\%) donde solo el 8\% tiene un contrato laboral formal (Portafolio, 2013). Dicha situación tiene serias consecuencias en términos de protección social y garantía de derechos derivados del trabajo para aquellas mujeres dedicadas a este oficio. 
Como lo menciona Anderson, citada en Todaro \& Yáñez (2004), p.63, “El trabajo doméstico, olvidado en la caja negra de la reproducción social, no figura en las cuentas nacionales, ni incide en el cálculo de la productividad o la riqueza de país alguno, ni (aparentemente) consume el tiempo o las energías de quienes lo realizan", en términos concretos es un trabajo que no se valora ni se le reconoce valor agregado, lo que dificulta enormemente su transacción sobre todo en el mercado laboral informal.

En la sociedad moderna cuyos valores principales son el dinero, el poder y la competencia, se considera que el trabajo doméstico es una labor de poco valor realizado por personas de poco valor, lo que justifica las relaciones serviles y el no reconocimiento de los derechos asociados al trabajo.

Quienes como Margarita se dedican al servicio doméstico en un contexto de informalidad laboral, al no ser propietarios de derechos sociales asociados al trabajo y no poder acceder a la propiedad privada debido a la poca remuneración, se encuentran en un contexto sin institucionalidad o mecanismos que les garantice sus derechos. Los dispositivos con los que cuentan para acceder a la protección social los constituyen las redes informales (familia o redes comunitarias); o el establecimiento de una relación asistencial con el Estado, que en ocasiones es de poca calidad y duración incierta, y que además exige la permanencia en la precariedad. Si bien el asistencialismo hace parte de los sistemas de protección social, constituye en sí mismo un síntoma de exclusión e injusticia social (CEPAL, 2005).

\section{EL TRABAJADOR CONTEMPORÁNEO: EL INDEPENDIENTE}

La globalización ha generado grandes cambios tanto en el mundo laboral como en la concepción del trabajo, uno de estos ha sido la flexibilización laboral en medio de la cual ha nacido 
una figura de trabajador individualizado que reúne los valores propios de la sociedad actual. El prototipo de trabajador moderno es aquel que se vende a sí mismo, él mismo es su mejor producto, se vende al mejor postor y por el tiempo que desee, rompe la "atadura" del contrato y del horario laboral ganando "libertad".

Sin embargo, este discurso encubre otra forma de dominación que no es colectiva sino individual, donde cada uno en lo suyo y todos contra todos. La idea ya no es "venceremos" (propia de la clase trabajadora fordista) sino "vamos a competir" (Castells \& Subirats, 2007). Este tipo de trabajador podría llamarse independiente o consultor y su descripción general es:

“[persona con buena formación y experiencia], con mucha más movilidad, que puede cambiar de sector, de empresa, de país; trabajar en la empresa que ayer era su enemiga (...) Lo que acumula es prestigio, dinero, relaciones y contactos, todo ello centrado en su persona, no en su puesto de trabajo. Tiene pues pocos proyectos compartidos; sus relaciones con los otros seres humanos son más instrumentales que emotivas. Su pasión es el triunfo y el camino que lleva a él: la competición. Compite en todo momento sin ningún tipo de concesión para alcanzar aquello que realmente le motiva: ser el número uno, el vencedor. Pero no al modo de un "superman" que combate los peligros que acechan a los débiles y promueve las causas nobles, sino por sus propios intereses, por aumentar su dinero, su influencia y su poder y derribar a sus contrincantes" (Castells \& Subirats, 2007, p. 96).

En ocasiones la opción de ser trabajador contemporáneo es tomada por decisión propia, pero también puede ser el resultado obligado ante la imposibilidad de encontrar una manera diferente de inserción laboral. En ambos casos tiene historias de éxito y fracaso; acá se presenta una historia de fracaso con el interés de evidenciar las consecuencias sociales y económicas de esas trayectorias. 
Para entrar en los círculos de artistas tienes que ser muy muy bueno y muy dedicado, hay algunos que corren con suerte y por medio de un trabajo de la universidad los invitan a exponer en una galería siendo estudiantes; otra forma de [desarrollo profesional] es haciendo un posgrado o ser profesor, es decir moverse por la pedagogía del arte o por el lado del arte social, aunque los docentes ahora son por contrato, no es muy bueno. Hay muchas formas de hacer arte, unas más guerreadas que otras; eso sí, para entrar en el círculo de la galería hay que tener ciertas palancas o ciertos apoyos

Yo pinté por encargo, pinté retratos, pinté finca, es el cuadro para la sala, ahí tú no estás haciendo arte simplemente estás ejerciendo una técnica, pero si te dan plata por eso... Posiblemente si tus clientes van diciendo de boca en boca, entonces puedes hacer dinero y paralelamente puedes estar haciendo tus trabajos de arte.

Ahora la mejor estrategia es la de presentar proyectos, es una muy buena estrategia presentar proyectos artísticos y culturales para que una organización o el Gobierno o el Distrito te los avale, te promueva y te pague por eso, es muy interesante; con mi amiga si nos teníamos que meter al grupo feminista para presentar un performance lo hacíamos, o si nos teníamos que meter luego al punketo, también lo hacíamos, o sea, se busca la manera; tuvimos un proyecto muy interesante que se llamaba museo portátil y era ir por varios departamentos de Colombia, recoger obras de artistas en esos Departamento y la cuestión histórica del Departamento; eso lo patrocinó el Idartes. De eso se puede vivir pero muy a ras, toca hacer otras cosas a la vez.

Toca multiplicarse, dar tallercitos de lo que sea en cualquier lado y multiplicarse, 0 sea yo trabajo acá de docente y acá vendo mis obras y acá puedo ganarme un premio si me 
presento a un salón de artistas y si afortunadamente me lo gano, son 15 o 20 millones; un artista se tiene que mover mucho, mucho si se queda quieto no puede.

Bueno cuando salí de la universidad me fui hacer un voluntariado en el que duré un año, y ahí me di cuenta que el arte no era solo el museo, porque empecé a ver otras maneras y otras formas de arte, me di cuenta que se podía enfocar a la sociedad y que se puede por medio del arte ayudar a una sociedad, a una comunidad o a un grupo de personas, así sea pequeñito. Cuando volví al país, me puse a vender tiquetes aéreos a San Andrés porque no encontraba nada y luego por la mamá de una amiga, que estaba en ese momento en Bienestar Familiar me ofreció unos talleres, era como 40 mil pesos por día, los martes y jueves; era en la Unidad de Atención a Víctimas, entonces mientras que los papás esperaban ser atendidos o eran atendidos, yo trabajaba con los niños de 4 a 14 años, analizando los riesgos psicosociales, entonces uno hacía que los niños dibujaran o por medio del juego dijeran cosas para que yo pudiera ir a contar, me utilizaban un poco; yo tenía que decir: - no está escolarizado, no desayunó y vive en hacinamiento, lo violan, ve a sus papás cuando tienen sexo o sea todas esa cuestiones y riesgos que podrían tener los niños; ahí duré un par de semanas.

Me volví a ir del país por unos meses, cuando volví, me fui a Caño Mochuelo en Casanare, al resguardo indígena y eso fue por la amiga de mi novio, así terminé en una cuestión de ser docente en un resguardo indígena, sin mucho arte o sea sin que dijera docente de arte ni nada de eso, simplemente docente, fue una cuestión con ICBF más para reafirmar los lazos entre madres e hijos, y entonces cada uno se tenía que inventar cómo lo hacía, pues yo tenía herramientas artísticas y las usaba, pero cada quien lo hacía a su manera, eso fue, en eso trabajé dos meses y ya. 
Después de eso me volví a ir de Colombia [a Argentina a estudiar arte terapia], dure como 7 meses sin trabajo en Argentina viviendo de mi mamá, como también he vivido desde siempre y de mi hermana, luego conseguí un trabajo de niñera y por medio ser niñera, di unos talleres de artes a niños chiquiticos fueron 4 talleres y ya, pagos pero hasta ahí, pero en Argentina lo que sí me di cuenta es que la demanda y la oferta artística es muchísimo más amplia.

Volví este año de nuevo al país, y me fui a vivir con mi novio; en este momento no tengo trabajo, no tengo nada, obviamente me siento inestable totalmente y es como ¿a quién me le pego?, me parece imposible que no pueda conseguir trabajo después de estudiar y haber hecho todo lo que hice, como que "estudie que eso le va a garantizar un futuro", es mentira!, no es verdad y yo no le creo a eso ahora, me parece imposible, llevo por lo menos 26 años estudiando, y no encuentro algo como una estabilidad económica, social, lo que quieras y me da raye.

Ahorita conseguí unos talleres, dar unos talleres de arte en una fundación donde me pagan 30 mil la hora, para mí eso es una maravilla, pero son dos horas a la semana, ¿con qué vivo?, eso no aporta nada, también ofrecí mi servicios de niñera, voy ofreciéndome por la vida cómo puedo, voy a la universidad a vender aretes, por 7 u 8 mil pesos.

Mi novio me va a afiliar a la EPS, eso me da raye también.

Yo no quiero un subsidio del Estado, ino es una alternativa!, o sea el Estado no me tiene que garantizar subsidio, sino trabajo, es eso abrir oportunidades a la gente, no subsidios.

En términos de Castell (2010) el trabajador contemporáneo exitoso es un "ciudadano por exceso", caracterizado por ser descolectivizado, desintitucionalizado, individualista y alejado de las 
pertenencias y valores colectivos; se define por poseer suficiente capital social, cultural, relacional y simbólico. La hipertrofia de su individualismo y autosuficiencia, destruye su sentido de lo colectivo y comunitario, viviendo en un vacío social cuyo objetivo es realizarse como individuo.

Por otro lado, el trabajador contemporáneo fracasado es un "ciudadano por defecto", que se encuentra atrapado en la contradicción de no poder ser el individuo que aspira a ser al no tener el o los capitales necesarios para hacerlo, aun así también desprecia lo colectivo y no comparte el sueño de la sociedad salarial de antaño sino que su deseo es ser su propio jefe; la mayoría de las veces se encuentran en una franca zona de vulnerabilidad (Castel, 2010). El individuo por defecto no tiene propiedad privada, propiedad social y tampoco capital social, cultural, relacional ni simbólico; se encuentra enmarcado en una dependencia patrono-laboral precaria y de subordinación, con una relación asistencial frente al Estado que en ocasiones significa su fracaso.

Para el caso de Marta se observa a una trabajadora independiente, que opta por ese camino debido a la difícil incorporación al sector cultural de la economía que crece debido a la expansión de la industria cultural (cine, televisión y conciertos) y a los emprendimientos culturales (proyectos individuales o colectivos de cuenta propia); empero, cuenta con una red familiar de gran soporte que le permite construir un buen capital social-relacional: niñez con acceso a cultura, educación superior, formación fuera del país, inclusive la posibilidad de tener pareja que le provee protección.

Marta no cumple el estereotipo propuesto por Castel de individuo por defecto, por el contrario cuestiona cómo una persona con tanto capital social-relacional no logra una adecuada inserción al mundo laboral y con ello la garantía de los derechos mediante un mecanismo formal; sin embargo ella ha cumplido su tarea en relación con aquella premisa de que estudiar es la garantía para la vida de éxito. 
El capital social-relacional de la protagonista le permite entender las implicaciones de la no incorporación en el mercado laboral y en ese sentido establecer un reclamo al Estado y el mercado como culpables de esta situación. Considera que ha cumplido en la medida que ha estudiado gran parte de su vida, reconoce el aporte que ha hecho su familia, pero resiente la ausencia de otros actores garantes de protección: el Estado y el mercado.

Esta es la principal diferencia con casos como el de Margarita o Manuel, quienes tampoco han logrado una incorporación adecuada al mercado laboral y el consecuente reconocimiento de derechos. Ellos no identifican una situación de negación de derechos, no establecen una relación problemática con la sociedad, ni reclamo con el Estado; sus pasados de precariedad y exclusión no les han permitido identificar al Estado como garante de derechos.

A través de algunos sucesos en la trayectoria laboral de Marta se evidencia el encuentro, en los programas asistencialistas, de dos poblaciones excluidas: por un lado quienes son los beneficiarios y por otro, las personas efectoras del programa (para el caso particular como docente en población indígena y en programa atención psicosocial en población infantil), convirtiendo las políticas y programas asistencialistas en el mecanismo proveedor de derecho al trabajo (para el efector del programa) y de derechos sociales: transferencias monetarias condicionadas, subsidios (para los sujetos de atención).

Este hecho, profundiza los precarios efectos de estas políticas y programas como dispositivos para garantizar los derechos, al revelar la frágil infraestructura sobre la que se construyen este tipo de intervenciones, que además de no contar con orientación hacia la inclusión social y productiva, en cuanto a los trabajadores (efectores) son una suerte de "escampadero laboral" que sólo permite la solución del problema de supervivencia temporalmente. 


\section{EL ADULTO CIUDADANO}

El fin del fordismo y la llegada de la globalización reformaron profundamente el modelo de producción, lo que también generó transformaciones en los derechos, la ciudadanía, la sociedad salarial y los sistemas de protección social.

La sociedad actual es individualista y los ciudadanos han dejado atrás las ideas de reivindicación colectivas, siendo la competencia y no la solidaridad el principal valor. Esta situación implica pensar una protección que dé cuenta de las necesidades y gustos individuales, a la vez que no permita exclusiones y precariedades sociales.

Para Castell con la fragmentación de los colectivos, muchas protecciones ya no pueden ser definidas y administradas en forma colectiva, y por lo tanto deben ser personalizadas. Es innegable que, en una sociedad de individuos, el Estado tiene la obligación de hacerse cargo en mayor medida de la especificidad de sus necesidades"(Castel, 2010, p. 337); para este autor en cuanto más individualizada es una sociedad más necesita del Estado.

En el ejercicio de entender las formas cómo se construyen las nociones de derecho y ciudadanía en la edad adulta, es necesario recalcar que en esta fase de la vida existe una centralidad en los derechos económicos, siendo la vía de acceso la inserción laboral, en la cual coexisten una amplia gama de matices.

Fundamentalmente hay dos maneras para gozar de ciudadanía plena: el contrato laboral formal y la propiedad privada, sin embargo resultan opuestos a la hora de definir las nociones de derechos y ciudadanía. Por un lado el trabajo formal, si bien requiere de un esfuerzo individual, depende del grupo de pares organizados (sindicatos, colectivo de trabajadores) y de cierta estructura laboral de las políticas públicas; por otro la protección de derechos vía propiedad privada, es 
estrictamente un camino individual de esfuerzo y competición, donde el mantenimiento depende de logros y batallas personales.

En otra área se encuentran quienes no tienen ciudadanía plena y el reconocimiento de sus derechos depende de factores como la seguridad nacional, las redes informales de protección y la relación asistencial con el Estado. Dentro de este segundo grupo también juega un papel determinante el capital social-relacional, el sector de la economía en la que se logre inserción y la calidad de la protección que brinda la red familiar.

Es evidente a través de las cinco trayectorias laborales, que los diferentes caminos de inserción laboral no se yuxtaponen en la vida de los individuos, es decir, quien entra al mercado en la informalidad se mantiene en ella y así para las demás opciones, determinando los derechos que le son reconocidos o negados y la consecuente relación con el Estado. 


\title{
FAMILIAS EN ACCIÓN
}

\section{FAMILIA Y RELACIONES DE GÉNERO}

\author{
¿Está usted sugiriendo que habría que dar a las mujeres \\ derechos sobre la tierra? ¿Qué quiere? \\ ¿Romper la familia? \\ Interpelación de Ministro de agricultura durante seminario de \\ la Comisión India de Planificación sobre reforma de la tierra. \\ Junio de 1989 \\ "Instituciones que parecen iguales siempre desde fuera, y que \\ llevan los mismos nombres, \\ pero por dentro son bastante diferentes. \\ Seguimos hablando de la nación, la familia, el trabajo, la \\ tradición, la naturaleza, como si todos fueran igual que en el \\ pasado. No lo son. \\ La parte exterior permanece, \\ pero por dentro han cambiado" \\ Anthony Giddens (2000). Un Mundo Desbocado. Los efectos de \\ la globalización en nuestras vidas.
}

Familia es el nombre asignado a una organización social tan antigua como la humanidad, que a lo largo de la historia ha experimentado transformaciones que le han permitido adaptarse a las exigencias de cada sociedad y época (Alarcón, 2008); definirla y concretarla en términos jurídicos no ha sido tarea fácil y aún hoy se encuentra en discusión. La tendencia actual es reconocerla como una institución dinámica constituida esencialmente por los lazos de afecto y cuidado que se tejen entre sus integrantes con el compromiso, implícito o explícito, de cuidarse los unos a los otros, superando su restricción exclusiva a lazos de consanguinidad o legales.

Siempre se ha reconocido su papel protagónico en la producción y reproducción del bienestar, por eso junto al Estado y el Mercado constituye la "triada de Bienestar" (EspingAndersen). Además de ser un espacio de intercambio en los momentos de estabilidad, en épocas de crisis las familias suelen movilizar sus activos, que pueden ser su fuerza de trabajo o sus bienes 
muebles o inmuebles para brindar la protección que algún integrante requiere; por tal razón, es central en los sistemas de protección social y en las políticas sociales. Sin embargo, su entrada en ese escenario surgió desde el paradigma de la familia nuclear tradicional, donde el hombre era el proveedor y la mujer la cuidadora, Castells y Subirats señalan:

"Familia, unidad de convivencia en la que el hombre era el rey de la casa. Y como herederos eran educados los niños, por riguroso orden de progenitura, mientras que las niñas aprendían pronto lo que les tocaba en la vida, jugando a muñecas, ayudando a mamá y poniéndose monas sin exagerar. El hombre era el cazador, el protector, el guerrero y el que traía el pan a la mesa, arando la tierra o fundiendo el hierro. También era el vínculo con el poder de la sociedad, político, militar y religioso, ya fuese para ejercerlo, participarlo o huirlo. Y en último término era el macho que germinaba a la hembra para reproducirse a cambio de saciar su sed sexual y afirmar su poder. Más allá de las funciones dominantes y elementales, poco más para los hombres, con la salvedad de poetas, bufones y otros marginales.

La mujer tenía que encargarse de todo el resto, es decir, de la vida en sus múltiples dimensiones y en sus insospechados derroteros. Pero primero tenía que seducir al hombre o conseguir que sus padres la colocaran con alguno. Era su única salida aparte de clausura en el convento o en el burdel (...) La función principal de la mujer era la reproducción de la especie. Vales lo que pares." (Castells \& Subirats, 2007, pp. 15-16).

Sobre ese paradigma fueron construidos los Estados de Bienestar, siendo central la figura de "hombre proveedor" y su correspondiente ama de casa. Dichos Estados procuraban garantizar y proteger el ingreso familiar a través de aquel hombre, razón por la que no se desarrollaron servicios 
sociales para el cuidado de los hijos o de los adultos mayores (Esping-Andersen, 2009). Este hecho, mantuvo el esquema tradicional de familia nuclear donde el hombre jefe de hogar es el encargado de trabajar, percibiendo un salario con el que asegura la manutención de todos los miembros del grupo, mientras la mujer tiene a su cargo las tareas de la casa y el cuidado de los hijos, a cambio de lo cual no recibe ninguna remuneración.

Sin embargo, la familia nuclear tradicional no es la única forma de organización familiar, para el año 2002 en la región Latinoamericana representaba el 42\% de todas las tipologías (Sunkel, 2006). La familia nuclear coexiste con familias monoparentales ${ }^{13}$, sin hijos, reconstituidas ${ }^{14}$, extensas ${ }^{15}$ y homoparentales ${ }^{16}$; lo cual hace necesario repensar acuerdos sociales y económicos en términos de protección social que respondan a las particularidades y exigencias de estos grupos.

No obstante las nuevas configuraciones familiares no han sido las únicas transformaciones, ya que han ocurrido importantes cambios socio-culturales como el aumento de la oferta educativa para las mujeres y su ingreso masivo al mundo laboral (Echeverri Angel, 2013). A través de la reconfiguración de las relaciones internas y la reasignación de reglas y roles, la familia ha conservado su papel como garante de derechos tanto en lo público como en lo privado.

El objetivo de este apartado es analizar cómo se configuran las relaciones al interior de las familias de los protagonistas, al ser un espacio donde se ponen en juego los derechos y en el cual existen tensiones entre los derechos individuales y los colectivos.

\footnotetext{
13 Familia monoparental es aquella donde solamente hay uno de los padres, bien sea por separación, muerte o inexistencia en caso de inseminación artificial. Puede ser madresolterismo o padresolterismo.

${ }^{14}$ Familia reconstituida es aquella donde hubo uniones previas de alguno o ambos integrantes de la pareja

${ }^{15}$ Familia extensa es aquella en la que al grupo familiar pertenecen personas de diferentes generaciones a la de padres e hijos, por ejemplo abuelos, tíos o primos.

${ }^{16}$ Familia homoparental es aquella conformada por una pareja del mismo sexo.
} 
Ahora bien, Familias en Acción es un programa del gobierno nacional que inició en el año 2000 como una de las estrategias generadas en el Plan Colombia, su crecimiento a lo largo de los años ha sido exponencial. Inicialmente era un programa piloto para atender a familias en extrema pobreza residentes en municipios con menos de 100.000 habitantes. En el año 2005 se incorporó al Sistema de Protección Social (Conpes 3359 de 2005), y en el año 2007 fue objeto de un importante escalamiento hasta transformarse en el componente principal de la estrategia de superación de la pobreza (Conpes 3472 de 2007).

En la presidencia de Juan Manuel Santos cambió su nombre a "Más familias en Acción", y en el año 2012 dejó de ser un programa social para convertirse en Ley de la República (Ley 1532 de 2012); catalogándose como "un derecho de las familias más pobres y vulnerables de Colombia" (Gobierno de Colombia, 2015). Consiste en la entrega periódica de una transferencia monetaria directa para complementar el ingreso y mejorar la salud y educación de las familias en situación de pobreza y vulnerabilidad (Congreso de Colombia, 2012); la transferencia está condicionada a la escolarización y controles de crecimiento y desarrollo de los menores de 18 años.

Como se señaló anteriormente, el objetivo de este apartado es el análisis de las relaciones al interior de la familia, no se hará un estudio de impacto, crítica o análisis del programa "Familias en Acción / Más familias en Acción"; el título obedece a su notoriedad como política pública dirigida a las familias. Sin embargo y pese a no profundizar en la política, se identifican características de las familias a tener en cuenta en el momento de diseñar políticas públicas. 


\section{FAMILIA PATRIARCAL}

Duré poco en ese trabajo porque conocí al papá de mis hijas (...) hubo una época bien, su merce sabe que al principio todo es color de rosa... a los 8 días ya me quería ir. Yo tenía 18 años cuando me casé con él, tomaba mucho, jugaba tejo y billar (...). Luego yo empecé a vender cositas en la casa, pero todo el dinero se lo daba a él, es que era más majadera...

Él era muy machista, por ejemplo, yo siempre quise darle estudio a mis hijas, lo mejor; pero como él tomaba tanto ya después ya no tenía un trabajo definido ni dinero, entonces decía que si no había plata, pues no había para el estudio de las niñas; yo lavaba ropa a escondidas de él para pagarle el colegio... nunca pensé en ahorrar un peso.

Cuando le celebramos los 15 años a la niña, él dijo que no había plata, entonces mi hermana la menor me apoyó para la celebración, es que ella quiere mucho a la niña.

Margarita, 59 años

La idea de familia patriarcal bajo el esquema de hombre proveedor-mujer cuidadora, no fue solo una invención para incorporar a la familia en los sistemas de protección social, sino que se trata de una forma de organización ampliamente aceptada que explica, para el caso de Margarita, por qué abandona el trabajo al momento de casarse y espera de su esposo la provisión de seguridad física y económica tanto para ella como para sus hijas.

No obstante ante el fracaso en el cumplimiento de esa expectativa, la decisión de Margarita es continuar el proyecto de familia con su esposo e hijas. A través de actividades informales y encubiertas, obtiene ingresos para garantizarle el acceso a la educación a sus hijas; esta situación 
expone dos características estructurales de las familias, la primera es que se construyen fundamentalmente sobre lazos de afecto sin definirse con criterios racionales o económicos. La razón por la que surgen o se acaban es la existencia o ausencia de afecto entre quienes la conforman, explicando el mantenimiento del grupo familiar pese al incumplimiento de las expectativas económicas.

La segunda, es la tensión constante entre el proyecto familiar y el proyecto individual. Un reto importante para cada familia es permitir y apoyar los deseos de sus integrantes, pero a la vez que ellos nutran el proyecto grupal, es la tensión entre los derechos del colectivo y de los individuos. Una familia garante de derechos, es aquella en la que a la vez que se desarrolla el proyecto familiar se respalda el desarrollo de cada uno de sus integrantes. Un proyecto familiar común que interfiere con el desarrollo individual, es la permanencia como grupo pese a la insatisfacción personal o el maltrato en su interior.

Otro aspecto a destacar al interior de las familias como parte del reconocimiento de derechos y oportunidades, es la igualdad de género entendida como "la imparcialidad en el trato que reciben mujeres y hombres de acuerdo con sus necesidades respectivas, ya sea con un trato igualitario o con uno diferenciado pero que se considera equivalente en lo que se refiere a los derechos, los beneficios, las obligaciones y las posibilidades"(Banco Mundial, 2012),

Reconocida ampliamente, la igualdad de género es un elemento indispensable para el desarrollo de las sociedades al generar beneficios sociales y económicos a través del aumento de la productividad y la competitividad de los países (BID, 2004); siendo la familia el primer escenario donde se aprende y aplica. 
En el caso de las mujeres, además de la igualdad de oportunidades se requiere su empoderamiento, siendo un aspecto central en la garantía de los derechos y la superación de las desigualdades de género. El principal elemento para el empoderamiento femenino lo constituye la autonomía económica, entendida como la capacidad de contar con sus propios ingresos, información, bienes y servicios logrando participación en la vida económica para el sostenimiento de sí mismas y la contribución al ingreso familiar; al igual que la libertad para decidir el uso del dinero ganado por su trabajo.

\section{LAS NUEVAS FAMILIAS}

Creo que fue una cuestión sin querer de mi madre, que cuando se separó de mi padre nos dijo [a las dos mujeres] ustedes son solas, hacen su vida solas, no tienen hombres, no dependen de hombres, estudian, se capitalizan y si quieren después se casan, después.

Cuando me fui a vivir con mi novio, y se lo dije a mi mamá fue como si me hubiera desheredado (...) me ha dado duro vivir con él y no aportar económicamente, es vergonzoso que yo sea su beneficiaria en salud, aunque sé que él ahora me da la seguridad que yo no me puedo dar es vergonzoso para mi depender de él, me cuesta mucho depender de un hombre, puedo depender de mi familia pero no de un hombre.

Yo soy de familia, pero de mi familia nuclear: mi mamá y mis hermanos, pensar que tengo una familia con otra persona me cuesta mucho, para mí, al inicio era más una sociedad pero poco a poco él me ha hecho comprender que somos una pareja.

Martha, 31 años 
El surgimiento de diversas configuraciones familiares ha generado nuevos valores culturales asociados con el matrimonio, la conformación de familia, la maternidad, la paternidad y las relaciones fraternales, explicando en parte por qué cada vez es más frecuente entre las parejas la conformación de "sociedades" en vez de familias. Para el año 2014 en Colombia, el 20\% de los adultos entre 18 y 49 años estaban casados y el $35 \%$ se encontraba en cohabitación con su pareja sin considerarse matrimonio (Lippman, Wilcox, \& Ryberg, 2014).

Más allá de las razones por las cuales sucede, en el campo de la protección social este fenómeno dificulta la protección de derechos a los integrantes de la unión, principalmente cuando termina. Con la intención de brindar protección a las personas en dicha situación, en Colombia se considera que una vez pasados dos años de cohabitación se establece la unión marital de hecho que significa una sociedad patrimonial no conyugal, otorgando derechos de propiedad sobre los bienes adquiridos durante la convivencia (Congreso de Colombia, 1990). El matrimonio es también una institución de amparo económico y la familia una red de soporte emocional, social y económico; parte de la calidad de esa protección sucede por la claridad de los lazos que definen la familia.

\section{LOS CONFLICTOS FAMILIARES}

[En la finca regalada por el suegro después del matrimonio], duramos 7 años viviendo, fue cuando ella se puso a hacer amable con un miliciano de la guerrilla, ella era tan jovencitica, no sabía nada, entonces pensó que conseguir otro hombre era normal, entonces ella quiso correrme a mí para quedarse con un miliciano de la guerrilla; fue la primer desterrada que tuve. 
[Después de hablar con la guerrilla] me dieron 3 días de plazo y ella se fue, me dejó solito ahí, ella cogió los niños y se fue, como ella era la que me los echo entonces ella se fue y me dejó ahí, me quedé ahí esa noche en la casa, al otro día me madrugué y me fui al pueblito a echarme al pueblito de mis papaés.

A los tres años volví (...) la niña tenía diez años y el niño tenía 11 iba para 12, estaban pequeños todavía (...) pero entonces mis hijos estaban cambiados ya..., ella les había infundido algo de mí: que yo los había dejado porque fui un irresponsable, entonces los niños estaban resentidos en ese sentido, (...) en tres años se apegan totalmente y le creen totalmente a la mamá. Ella [la esposa] estaba sola, no estaba con el guerrillero.

[La familia de ella] sabían que era ella la culpable de todo, a mí me estimaban por el trabajo, como ella salió de un temperamento pero áspero que no la iba ni con los mismos papaés, entonces era lo que ella dijera, salió una persona muy machista, no acataba consejos de nadie (..) pero era muy de trabajo, muy ahorrativa.

Manuel, 51 años

Además del hecho de que este relato ocurre en medio del conflicto colombiano y que el resultado final es el desplazamiento forzado para uno de los miembros de la familia; vale la pena anotar que el actor armado está inmerso en un conflicto de pareja y la historia sucede en una población con casi nula presencia del Estado, en la que la autoridad es ejercida por un grupo guerrillero que representa la instancia a la cual recurrir para solicitar la protección de los derechos. 
Sin consideración de los motivos, es evidente que la esposa de Manuel no deseaba continuar el matrimonio, pero quería conservar sus hijos y las tierras otorgadas por su padre en razón de la unión; ese deseo significó para Manuel la amenaza contra su vida, la pérdida de propiedad sobre la tierra y la imposibilidad de participar en la crianza de sus hijos.

Este suceso que resulta en la completa vulneración de los derechos de Manuel y sus hijos, recalca la importancia de aumentar la institucionalidad para proteger los derechos de las familias como colectivo y de cada uno de sus integrantes, durante la duración del matrimonio y sobre todo cuando se termina la relación de pareja y existen hijos y bienes materiales de por medio.

\section{LA FAMILIA “CIUDADANA"}

Las familias, sin importar cómo se organicen y la diversidad de significados a ellas asociados, constituyen para mujeres y varones un eje central de sus vidas. Es un núcleo estructurador de la existencia, así como un elemento que otorga sentido e identidad, siendo parte sustancial de la vivencia subjetiva.

En este sentido, las relaciones que se establecen en el espacio familiar, su contribución a la generación de seguridades básicas y al desarrollo de capacidades individuales, así como el aprendizaje de obligaciones, responsabilidades y derechos entre sus miembros, son factores esenciales para la construcción de ciudadanía social, política y civil.

En términos de derechos las familias son un espacio paradójico, por un lado pueden ser protectoras contra los riesgos y garantes de cuidado, pero también reproductoras de asimetrías de género, de subordinación femenina y transgresiones a los derechos individuales de sus miembros. 
Para cuidar a las familias y potenciar su función como espacio garante de derechos, son necesarias acciones en tres sentidos: en la modificación de estereotipos, prejuicios y estigmas que reproducen las inequidades de género; en el desarrollo de mecanismos de protección de derechos individuales de quienes conforman el grupo familiar, inclusive la protección de los otros miembros de la familia; y finalmente acciones para que las mujeres-madres tengan garantías de empleos de por vida, en condiciones de equidad e igualdad de género, es decir, que se debe apoyar a las madres trabajadoras y minimizar la inseguridad económica de las familias con hijos (Esping-Andersen, 2004). 


\title{
COLOMBIA MAYOR
}

\section{VEJEZY PENSIÓN}

\author{
La vejez... es la antesala de lo inevitable, \\ el último camino transitable \\ ante la duda... ¿qué vendrá después?; \\ La vejez es todo el equipaje de una vida, \\ dispuesto ante la puerta de salida \\ por la que no se puede ya volver. \\ La vejez... es la más dura de las dictaduras, \\ la grave ceremonia de clausura \\ Alberto Cortez \\ La Vejez
}

Colombia tiene hoy la mayor cantidad de personas mayores de 60 años que nunca antes en la historia. De acuerdo con proyecciones del DANE, actualmente existen 5,5 millones de personas de 60 años o más, lo que representa el 11.3\% de la población (DANE, 2015); adicionalmente, se proyecta que para el año 2050 los mayores de 60 años significarán el 23\% de la población colombiana. Este fenómeno es denominado "Transición Demográfica", que en términos concretos significa una disminución en las tasas de natalidad y de mortalidad con el consecuente aumento de la población mayor y un decremento en la población menor. Expertos coinciden en que este fenómeno en América Latina ha sucedido muy rápidamente (Fedesarrollo \& Fundación Saldarriaga Concha, 2015), explicando en parte la precariedad con la que envejecen las personas en la región.

El envejecimiento poblacional plantea varios desafíos en términos de la protección social, ya que implica: i) ajustes en los servicios de salud, debido a su mayor demanda por parte de las personas mayores; ii) ajustes en la organización del cuidado, por el aumento en los índices de dependencia característico de una población envejecida y iii) ajustes en los programas de asistencia social y sistemas de pensiones, ante la pérdida de capacidad de generar ingresos derivada de la vejez. 
En este apartado se hará énfasis en el último aspecto, considerando que es la protección económica el principal garante de los derechos y las libertades en la vejez, al permitir la vivencia de una vejez con autonomía, independencia y dignidad. Se explorarán las visiones y proyecciones que algunos de los protagonistas de este relato tienen sobre su futura vejez, puesto que ninguno actualmente hace parte de ese grupo poblacional pero sienten su cercanía y han tomado medidas para su llegada.

Al revisar la oferta pública de protección social para la vejez colombiana desamparada, se encuentra que el principal programa se enmarca en el Consorcio Colombia Mayor, que consiste en una alianza estratégica entre sociedades fiduciarias del sector público: FIDUPREVISORA S.A., FIDUCOLDEX S.A. y FIDUCENTRAL S.A., y tiene por objeto administrar los recursos del Fondo de Solidaridad Pensional. Como administrador fiduciario está a cargo de las subcuentas de solidaridad y subsistencia, con las que financia el Programa de Solidaridad con el Adulto Mayor: Colombia Mayor y el Programa de Subsidio al Aporte en Pensión.

El Programa de Solidaridad con el Adulto Mayor: Colombia Mayor, busca aumentar la protección de los adultos mayores que se encuentran desamparados, que no cuentan con una pensión o viven en la indigencia o en la pobreza extrema. Este amparo se realiza por medio de dos modalidades: a) Subsidio económico directo que consiste en un beneficio otorgado en dinero y entregado a la población de la tercera edad que cumpla con los requisitos establecidos; este beneficio es intransferible y b) Subsidio económico indirecto otorgado en servicios sociales básicos y entregado a través de los Centros de Bienestar del Adulto Mayor (CBA) o centros día.

Otro programa del consorcio es el Programa de Subsidio al Aporte en Pensión, que constituye un aporte destinado a grupos poblaciones que por sus características y condiciones no tienen acceso a los sistemas de seguridad social, tales como trabajadores independientes urbanos y rurales, 
desempleados, madres comunitarias y personas con discapacidad, pertenecientes a municipios de categorías 4, 5 y 6. En este programa los beneficiarios deben aportar un porcentaje del monto total de cotización que oscila entre el 5\% y el 30\% dependiendo del grupo poblacional al que pertenezcan. El porcentaje restante lo subsidia el gobierno nacional a través del Consorcio Colombia Mayor (Ministerio del Trabajo, 2013).

Estos dos programas dan cuenta de la oferta Estatal de asistencia para el adulto mayor desamparado. En este apartado no se hará una revisión o estudio de impacto de los programas del Consorcio, su uso en el título no tiene ninguna relación con los programas Colombia Mayor o Programa de Subsidio al Aporte en Pensión. A través de los relatos se pone en evidencia la importancia de la protección económica en la vejez, la dificultad para acceder a ésta y la insuficiente de protección social para la vejez en Colombia.

\section{VEJEZ DE CARIDAD}

Uno no debe ser un estorbo para los hijos, no debe traerles problemas a los hijos, es mejor que lo dejen a uno en un ancianato, en un geriátrico (...) para mi tendría que ser de los públicos, de los del gobierno [gratis], pues es que uno no tiene dinero para pagar nada, y si hay personas con casa a las que le dan ese beneficio, ¿por qué a mí no? Que no tengo casa, aunque a veces toca con palanca, como todo...

Margarita, 59 años

Ésta es la perspectiva de vejez que tiene una mujer que a lo largo de su vida ha estado entre la precariedad y la exclusión; fue sacada de su casa tempranamente para que mediante la realización de labores domésticas se le permitiera, lejos de sus padres, el acceso a la educación. Después estableció un matrimonio en el cual se le adjudicaron todas las labores domésticas, y 
progresivamente tuvo que asumir las responsabilidades de provisión económica, hasta ser ella quien se ocupara de la totalidad del cuidado de su familia porque su esposo se marchó de casa. Se insertó en el mundo laboral a través de un trabajo informal y precario en el que jamás ha tenido reconocimiento de los derechos correspondientes ni ha podido acumular capital.

Ahora a portas de la vejez y de la pérdida de capacidad para producir dinero, considera que solo puede aspirar a tener un envejecimiento de caridad para no ocasionar dificultades a sus hijas; pues sabe que la frágil red de protección que posee no soportaría el peso de un anciano enfermo y no productivo. A través de Margarita se observa cómo una persona que no ha conocido la garantía de sus derechos, al final de su vida sólo reclama la caridad del Estado que le permita envejecer y morir con algo de dignidad y sin empobrecer a su familia.

Son pocos los datos que existen sobre la oferta de servicios de hogares geriátricos para los ancianos desamparados a nivel nacional, la mayoría de veces la provisión de este tipo de servicios obedece a iniciativas locales (Distritales o Municipales), puesto que no hay en Colombia una organización social del cuidado del adulto mayor como si se encuentra para la niñez y en parte para la discapacidad.

En el Distrito Capital, la oferta de este tipo de servicios se encuentra bajo la dirección de la Secretaría de Distrital de Integración Social y consta de los siguientes programas (Secretaría de Distrital de Integración Social, 2015):

- Centros Día: Es un servicio social de atención integral durante el día, diseñado para personas mayores en quienes se identifique vulneración en su integridad y requieran acompañamiento social para estimular procesos de autonomía. Este servicio promueve el ejercicio de los derechos en el marco de la seguridad humana, favoreciendo el envejecimiento activo, trabajando la responsabilidad intergeneracional involucrando a 
las familias y a la comunidad y contribuyendo a disminuir la segregación social por edadismo.

- Centros noche: Es un servicio transitorio de atención integral que busca garantizar un alojamiento seguro para personas mayores de 60 años que no cuentan con un domicilio permanente para pasar la noche, el objetivo es garantizar la restitución de derechos a través de la satisfacción de necesidades básicas como: dormitorio, alimentación y actividades de desarrollo humano que promuevan un envejecimiento activo. Este servicio se presta durante 12 horas de domingo a domingo.

- Apoyos para la seguridad económica: Dirigido a personas que se encuentran en situación de discriminación y segregación socioeconómica que no cuentan con pensión o carecen de ingresos o rentas suficientes para subsistir o satisfacer sus necesidades básicas. Su interés es contribuir al desarrollo y fortalecimiento de las capacidades y potencialidades de las personas mayores en situación de discriminación y segregación socioeconómica de la ciudad de Bogotá.

- Centros de protección: Dirigido a las personas mayores de 60 años que presentan dependencia moderada o severa sin redes familiares o sociales de apoyo y se encuentran en situación de fragilidad y vulnerabilidad social. Se realizan acciones integrales interdisciplinarias en el marco de los enfoques de derecho y desarrollo humano.

Cabe anotar que esta oferta de servicios no es igual en todo el territorio nacional y en Bogotá es insuficiente

"A veces se mueren esperando un cupo, porque éstos dependen de los reintegros que se realicen o de los procesos de vida que se puedan llevar o fallecimiento. Infortunadamente es 
demasiada la demanda que existe y muy poca la oferta que hay para las necesidades de la población", palabras de una funcionaria de un centro de protección" (Bonilla Mora, 2009).

Aunque necesaria para quien se encuentra en situación de vulnerabilidad, la caridad y la asistencia constituyen en sí mismas la ausencia de un derecho, en este caso el de una vejez digna con autonomía e independencia.

\section{VEJEZ SEGURA}

Nunca coticé a pensión, en salud soy beneficiario de mi esposa. Antes yo no había pensado en el futuro, tendría unos 30 y pico de años, cuando me empecé a dar cuenta del sufrimiento de la gente para pensionarse, inclusive mi papá, muchas personas cumplían los requisitos, y aun así tenían que hacer mucho papeleo; entonces yo decidí invertir en finca raíz y que esa fuera mi pensión.

Para mí mi pensión son los bienes e inmuebles que tengo, esa es mi pensión porque yo no creo hoy en día en la pensión del estado, la verdad no creo en esa pensión, es mi criterio propio, entonces para mi es mejor tener " $X$ " cantidad de inmuebles en renta, eso lo tomo como mi pensión y así he hecho; actualmente la verdad estoy viviendo es de eso.

José, 50 años

Al contrario del caso anterior, esta es la historia de un hombre que por una lucha aparentemente individual, logró en su época de mayor productividad económica conseguir capital suficiente para acceder a los derechos vía mercado y protección de la propiedad privada. Estos soportes le garantizan una vejez con autonomía económica, dignidad y libertad. 
José no requiere los beneficios de un sistema de pensiones, de reparto, de ahorro individual, ni de programas de asistencia estatales porque sus propiedades le permiten estar tranquilo y seguro respecto a su vejez. La relación con el Estado y el mercado en ese sentido, consiste en la garantía de la protección de la propiedad sobre sus bienes; de nuevo la propiedad privada aparece como elemento garante de derechos.

\section{VEJEZ INCIERTA}

[Respecto a la vejez] Eso no, yo tengo como cita que no voy a durar mucho tiempo, yo creo que mi diosito me lleva rápido, porque he sufrido tanto. Yo nunca aspiro a ser viejo, más viejo no, yo no soy para eso, no pienso en la pensión porque no voy a durar tanto.

Ahora no me siento viejo, pero al mismo tiempo pero me canso mucho, entonces como que no quiero ni vivir mucho, porque tanto que sufrí, tanto que he luchado y uno solo es bravo, entonces no aspiro para una vejez.

Manuel, 51 años

Esta es la perspectiva de un hombre que por las exigencias de la vida en el campo y la guerra colombiana ha aprendido a empezar cada día, a levantarse y seguir sin dudar de su capacidad y su valor. Ha tenido pocas certezas en la vida y los derechos le han resultado esquivos, encontrado la manera de garantizárselos casi siempre desde el esfuerzo individual. No tiene entre sus planes envejecer, como tampoco tenía el ser obligado a abandonar su familia, su tierra y luego su negocio. Vivir la vida resolviendo contingencias le ha quitado la posibilidad de proyectar, prever y ahorrar, fortaleciendo sólo su capacidad para resolver urgencias. 


\section{EL VIEJO CIUDADANO}

El objetivo del sistema de seguridad económica para la vejez (sistema de pensión) es cumplir tres funciones: redistribución, ahorro y seguro. Este sistema debe facilitar la acumulación de ingresos de la población trabajadora, con el fin de prepararla para las etapas posteriores de su vida y brindar protección económica frente a la incapacidad laboral y demás contingencias derivadas de la vejez (Fedesarrollo \& Fundación Saldarriaga Concha, 2015).

En Colombia, el Sistema General de Pensiones fue diseñado por la Ley 100 de 1993, en él coexisten dos esquemas que compiten por afiliados entre el mismo grupo poblacional. Uno es el Régimen de Prima Media (RPM) que es administrado por el Estado en cabeza de Colpensiones y se basa en el reparto. El otro, de carácter privado, es el Régimen de Ahorro Individual con Solidaridad (RAIS), gestionado por las Sociedades Administradoras de Fondos de Pensiones.

Tanto el RPM como el RAIS tienen condicionamientos en términos de las contribuciones que los trabajadores hayan hecho durante la vida laboral para tener acceso a una pensión, la cual no puede ser inferior a un salario mínimo de acuerdo con la Constitución de 1991. Adicionalmente se cuenta con el pilar de ahorro voluntario complementario para las personas con mayor capacidad de ahorro, y con un incipiente pilar no contributivo que busca garantizar un ingreso mínimo para la población más vulnerable a través del programa Colombia Mayor (Fedesarrollo \& Fundación Saldarriaga Concha, 2015).

La cobertura del sistema pensional puede medirse por la relación entre los cotizantes efectivos y la población económicamente activa. Para 2013 estaba en el 30\%, pero el aumento de este indicador ha sido poco en las últimas décadas. Si se analiza por estratos socioeconómicos, se encuentra que sólo el 15\% de la población de ingresos bajos cotiza a un sistema de pensiones, el 40\% de la clase media e igualmente el 60\% de la clase alta (Fedesarrollo \& Fundación Saldarriaga Concha, 
2015). De todo el grupo de pensionados, las personas mayores de 60 años representan tan sólo el $23 \%$, y la mayoría recibe entre uno y dos salarios mínimos, indicando las difíciles condiciones de los viejos en Colombia.

También existen otros mecanismos de ahorro para la vejez como la acumulación de activos, el patrimonio en especie e inclusive, según algunos autores, la inversión en la educación de los hijos. Sin embargo, éstos no son fáciles de medir por lo que resulta complicado hacer un diagnóstico en la población colombiana. Aun así y de acuerdo con las experiencias recogidas, se puede plantear que este tipo de prácticas dependen del nivel de ingresos y de la capacidad de ahorro de las personas y sus hogares, no son de libre elección sino el resultado de condiciones determinadas fundamentalmente por el mercado laboral.

Quienes no logran una inserción formal y el acceso a activos y capital para construir patrimonio, carecen de un sistema de apoyo económico estructurado para su vejez, lo que significa la no garantía de sus derechos y la condición de ciudadanía invertida ${ }^{17}$.

La protección en la vejez, fundamentalmente la económica, no puede ser entendida exclusivamente como el resultado de la acumulación juiciosa de capital durante la edad productiva, debe comprenderse como el derecho al goce legítimo de la herencia social generada por el aporte realizado con el trabajo, cualquiera que éste sea. Esta perspectiva obliga a poner en el centro la solidaridad intergeneracional, no sólo como necesaria para el funcionamiento de los sistemas de pensión basados en el reparto, sino también como pilar de la organización social del cuidado necesario en una sociedad que envejece.

\footnotetext{
${ }^{17}$ Condición de ciudadanía en la que desaparece la relación entre los derechos y obligaciones. La gratuidad de servicios sociales depende de ser definido pobre o excluido. El fracaso social otorga el derecho a recibir bienes sociales de forma gratuita (Giraldo, 2008).
} 


\section{CONCLUSIONES}

Después de la Declaración Universal de los Derechos Humanos (1945), se acordaron las condiciones que le deben ser otorgadas a cada ser humano en una sociedad que se considere a sí misma civilizada y democrática. Aunque el acuerdo es general, se hizo la salvedad de que cada nación encontrara el camino para garantizar a todos los habitantes la totalidad de los derechos y con ello la ciudadanía plena.

Colombia ha suscrito la mayoría de los pactos internacionales en materia de derechos humanos y en la Constitución Política de 1991, ratificó la intención de protección y garantía de los derechos civiles, políticos, sociales y culturales a los ciudadanos, sin embargo las cifras son contundentes a la hora de comprobar el no cumplimiento de lo pactado: las víctimas del conflicto armado, la informalidad laboral, la baja cobertura del sistema de pensiones, el trabajo infantil, entre otros.

Pero no todo es exclusión, también hay reconocimiento de derechos, en Colombia coexisten diferentes formas de ciudadanía, lo que significa que no todos tienen los mismos derechos y que por lo tanto la relación de los habitantes con el Estado no es igual en todos los casos. Las cinco trayectorias de vida abordadas en este escrito permiten concluir que entre los extremos de la exclusión y el reconocimiento pleno, se encuentran cinco tipos de ciudadanía, algunas ya descritas en la literatura: la no ciudadanía, la ciudadanía invertida, la ciudadanía parcial, la ciudadanía plena individual y la ciudadanía plena colectiva; cada una se construye como resultado del lugar de origen, del nivel educativo, del capital social - relacional y sobre todo de la inserción que se haga al mundo laboral y/o el acceso a los medios de producción. Según lo encontrado en estas historias de vida, el tipo de ciudadanía no es intercambiable sino que es asignada durante toda la vida. 


\section{NO CIUDADANÍA}

Este tipo de ciudadanía está ubicada en el extremo de la exclusión social; la primer característica es ser de origen rural, le siguen el poco acceso a la educación, ninguna posibilidad de recreación, ocio o deporte durante la infancia, exigencias de aporte a la economía familiar, inexistencia de un periodo de adolescencia claramente definido y finalmente ser víctima del conflicto armado, que ocasiona el despojo de la tierra y la pérdida familiar.

Esta trayectoria muestra que en ningún momento de la vida este individuo ha tenido garantía estatal o institucional de sus derechos, ni siquiera del más primordial como lo es la protección de la vida; el concepto "todos somos libres e iguales" no ha sucedido en su vida, jamás ha sido sujeto de protección por parte del Estado; quien ha fracasado en esta tipología de ciudadanía es el Estado.

Las garantías, libertades y derechos que esta persona conoce son los que se ha asegurado a sí misma, no reclama al Estado ni siquiera una relación asistencial, "los derechos" que solicita en la cotidianidad son los relacionados con la posibilidad de transar su fuerza de trabajo en condiciones dignas para acceder al capital que le permita la garantía de sus libertades.

\section{CIUDADANÍA INVERTIDA}

Esta tipología sucede en la periferia de la urbe, comparte con la anterior la infancia precaria con limitación en el acceso a la educación, nula posibilidad de esparcimiento, arte y recreación, pero con un componente determinante: el trabajo infantil con relación de servidumbre y dependencia; lo que en la vida adulta marcará el tipo de relaciones que establezca en el mundo. 
Su configuración familiar es la patriarcal tradicional, nuevamente en una relación que espera sea de dependencia con la pareja, pero contrario a las expectativas se le exige aportar económicamente mientras es vulnerada la autonomía económica. En relación con el mundo laboral, logra inserción en un oficio de poco reconocimiento social, en el cual no es fácil transar su mano de obra, generalmente desempeñada en condiciones de informalidad y precariedad sin reconocimiento alguno de los derechos asociados al trabajo. En cuanto a los otros componentes de la triada de bienestar, la familia es la red frágil que le provee estabilidad, protección económica, social y emocional. El Estado, previo reconocimiento de su condición vulnerable, le permite una relación asistencial como la vinculación al régimen subsidiado de salud y la entrega periódica de beneficios económicos.

En estas condiciones, es poco probable interiorizar la idea de que hay una dignidad humana en cada individuo que le otorga valor sólo por existir; por lo tanto lo que se recibe de la familia, del mercado y sobre todo del Estado constituye una dádiva. Específicamente la relación con el Estado se desarrolla desde la condición de precariedad, vulneración y exclusión, lo que éste ofrece es una ayuda que apacigua su situación, pero no los mecanismos y dispositivos contundentes para la concreta garantía de los derechos.

Este es el tipo de ciudadanía propuesta por Fleury (1997), para la autora se trata de un "modelo asistencial donde las acciones, de carácter emergencial, están dirigidas a los grupos de pobres más vulnerables, y se inspiran en una perspectiva caritativa y reeducadora... Aunque permitan el acceso a ciertos bienes y servicios, no configuran una relación de derecho social, tratándose de medidas compensatorias que terminan por ser estigmatizantes... el individuo tiene que probar que fracasó en el mercado para ser objeto de la protección social" (Fleury, 2007). 


\section{CIUDADANÍA PARCIAL}

La consolidación de este tipo de ciudadanía consiste en la garantía de la mayor parte de los derechos, sobre todo los relacionados con la infancia y la educación básica, media y superior, una red familiar sólida y un buen capital social-relacional y cultural. La principal restricción por la que no se considera una ciudadanía plena, es la dificultad para insertarse en el mundo laboral / productivo de una manera estable que permita la acumulación de capital.

Pese a esta dificultad, que de alguna manera comparte con los dos tipos de ciudadanía anteriores, esta ciudadanía es diferente por dos razones: la primera consiste en que el gran capital social-relacional posibilita no estar en una situación de vulnerabilidad o exclusión, si bien no se produce dinero en la trayectoria de vida la familia, tanto de origen como construida, provee de la seguridad y los recursos económicos necesarios para el desarrollo de proyectos personales, no se es un fracasado social y por tal razón no es sujeto de asistencia social.

Otra distinción derivada de su capital social-relacional, consiste en la identificación de una falla del Estado en la provisión de posibilidades de ingreso al mundo laboral/productivo, no se considera que las dificultades para acceder al mercado laboral sean por cuenta propia o falta de esfuerzo personal, sino que se ha incumplido la promesa de una sociedad en la que todos aportan desde su potencialidad particular, haciendo que se establezca una relación de reclamo con el Estado en términos de garantías de derecho. 


\section{CIUDADANÍA PLENA INDIVIDUAL}

Este es el primer tipo de ciudadanía plena, se goza de la protección y reconocimiento de los derechos civiles, políticos, económicos y sociales, pero su vía de acceso es primordialmente la protección a la propiedad privada y el mercado. Como fue definido en el siglo XVII, la protección a la propiedad privada y la renta es la primera cuota para la consolidación de la ciudadanía plena.

Sin embargo, al tratarse de un camino individual para la provisión de los derechos existe la posibilidad de pérdida de los mismos si se llegara a perder los bienes muebles, inmuebles o la capacidad de trabajar en razón de la enfermedad o invalidez. En cuanto a la familia, ésta participa en la construcción y acumulación de capital, donde el proyecto familiar reside en la preservación de las condiciones de protección. En cuanto al mercado, la relación con éste consiste justamente en la definición de escenarios en donde se haga posible el crecimiento de capital: mercado para sus productos, políticas laborales, políticas fiscales, etc.

La relación con el Estado es discrecional, no se considera como fuente de derechos y las exigencias que se le hacen están dirigidas a la protección de la propiedad privada y al favorecimiento fiscal para la acumulación de capital. En este caso, los derechos son el resultado del trabajo y el esfuerzo personal, no son garantizados para todas las personas sino para aquellas que los han ganado mediante el aprovechamiento de las oportunidades.

La definición acá planteada puede semejarse a la propuesta por Lo Vuolo (2009) como ciudadanía patrimonial, en la cual "lo que se premia es la capacidad para generar ingresos desde la propiedad de activos. La sociedad se vuelve más desigual y se diluye la solidaridad de clase a favor de una solidaridad con el valor de los activos financieros" (Lo Vuolo, 2009, p. 199). 


\section{CIUDADANÍA PLENA COLECTIVA}

Este es el tipo de ciudadanía clásica del Estado de Bienestar europeo descrito por Thomas Marshall, que logra a través del trabajo formal establecer su proyecto de vida y planear su futuro y el de su familia. Históricamente se logró consolidar por las reivindicaciones de los trabajadores-obreros y continúan existiendo gracias al colectivo trabajador organizado.

Sin embargo, en la trayectoria descrita se ha perdido el reconocimiento al colectivo de trabajadores como condición para la garantía de derechos, instalándose un discurso de mérito y esfuerzo personal que legitima la garantía de la que se goza y genera la disminución de la cohesión social y el proyecto común dentro de la clase trabajadora.

El hecho de que las protecciones de las que se goce continúen en caso de perder la capacidad de generar ingresos por enfermedad o discapacidad, constituye la más importante diferencia con la ciudadanía plena individual, en este tipo de ciudadanía los derechos adquiridos por el trabajo se hacen extensivos a la familia. El mundo productivo/laboral (mercado) es estable y permite la proyección hacia el futuro, donde el Estado es la principal garantía de mantenimiento de los derechos.

Una vez descritas las trayectorias ciudadanas, el contexto en el que se desarrollan y las implicaciones que tienen en términos de la relación de los individuos con el Estado, se plantean a continuación otros hallazgos de esta investigación. 


\section{HALLAZGOS ADICIONALES}

En las cinco historias son mínimas las referencias que se hace a la solidaridad, la cohesión social y la identidad nacional. Todas las trayectorias coinciden en un discurso individual ya sea de éxito o de fracaso, en el que no se reconoce el rol de las interrelaciones sociales en la cimentación de la nación. Este hecho dificulta la construcción de un tejido social sobre el cual se pueda consolidar una ciudadanía que cobije a todos por igual.

En la vida de estas cinco personas llama la atención la casi nula alusión que se hace a los derechos culturales, tan sólo se refiere a ellos quien vive del arte, aunque para ella los derechos culturales se interceptan con los laborales; para los otros cuatro protagonistas estos derechos son imperceptibles. Los derechos culturales fueron los últimos derechos reconocidos, es decir, que históricamente se han desarrollado después de la consolidación de los derechos sociales, aunque en Colombia aún no se llega a ese punto.

En cuanto a los aportes al posconflicto, se considera que el primer paso para la paz es construir ciudadanía, convirtiendo a todos los colombianos en sujetos de derecho. Esta tarea es urgente y necesaria en aquellos lugares donde no han cesado las inclemencias de la guerra y los actores del conflicto han acechado de forma permanente. En estos lugares, no ha existido una presencia real y efectiva del Estado, el cual se manifiesta fundamentalmente con asistencialismo, allí son las fuerzas al margen de la ley quienes tomaron la tarea de regular y controlar la seguridad, la economía y la justicia (todas tareas del Estado).

La tarea de construir ciudadanía en Colombia no es fácil, puesto que la precaria institucionalidad del país y la usual relación del Estado con los colombianos, sobre todo con los 
excluidos, se ha construido principalmente desde el asistencialismo en el cual se reivindica "el derecho al subsidio" negando la ciudadanía plena. En una situación de posconflicto, se requiere una profunda redefinición de los acuerdos sociales, caminando con paso firme hacia una sociedad más justa, más equitativa y más incluyente, donde todos los colombianos sean reconocidos y tratados con igualdad de derechos.

Los enfoques de investigación cualitativa han estado tradicionalmente fuera de la formulación, implementación y seguimiento de las políticas públicas. Estudios como este ponen en evidencia que en el mundo social, objeto de las políticas públicas, coexisten y se yuxtaponen matices propios de la humanidad y de las relaciones entre los seres humanos que escapan a los números característicos de los enfoques cuantitativos, pero que determinan el funcionamiento como sociedad. Por lo tanto, metodologías como la utilizada en esta investigación deben ser de uso frecuente en el escenario de la política pública.

El análisis de las trayectorias de vida permite capturar la ciudadanía en su procesualidad, acceder a su carácter dinámico y cambiante, y superar la idea de una ciudadanía estática que se alcanza en ciertas condiciones coyunturales y que como visión ideal es inalcanzable en realidad, atizando la frustración y la sensación de desprotección social. La vida de las personas es de por si la historia de un transcurrir permanente entre derechos realizados y vulnerados, ella refleja los cambios en las dimensiones de la ciudadanía. Así, mientras algunos realizan la dimensión económica, pueden ver debilitada su ciudadanía cultural. O mientras el derecho al voto es pleno para amplios sectores de la sociedad, la segregación o la exclusión por razones de clase, de cultural o género amenazan los proyectos vitales con tanta gravedad como las carencias económicas. 
Comprender el cambio en la situación de los derechos de las personas a lo largo de sus vidas o la manera como se van acumulando las experiencias exitosas o fallidas de ciudadanía puede informarnos sobre la situación actual de nuestro país, sobre la manera como se construye la cultura política de los ciudadanos, sobre sus nociones en torno al Estado social de derecho, sobre los derechos como insumos fundamentales de la protección social en el mundo contemporáneo y sobre los retos que debemos afrontar hacia futuro. Por lo tanto metodologías como la utilizada en esta investigación podrían ser mejoradas y empleadas con mayor frecuencia en el escenario de la investigación y la institucionalidad de la protección social.

Finalmente, se identificaron las siguientes limitaciones de la investigación; si bien se parte de la idea de que la ciudadanía es una categoría multifacética y que debe comprenderse en un contexto social particular, y que Colombia es un país pluriétnico y multicultural con los personajes incluidos no fue posible explorar las particularidades de la ciudadanía étnica. Cada uno de los capítulos aborda un tema de importancia para la protección social y esta investigación no pretende agotar la discusión al respecto, se considera que los hallazgos acá plasmados son un excelente punto de partida para abordar cuestiones tan complejas como si los niños y niñas nacen ciudadanos o se hacen ciudadanos, las condiciones para que un colombiano pueda acceder al mercado laboral o las implicaciones de las nuevas configuraciones familiares en términos de la protección social. 


\section{CONSIDERACIONES ÉTICAS}

Esta investigación se fundamentó en el respecto por la dignidad e integridad de los participantes así como la protección de sus derechos a la autodeterminación e intimidad y bienestar; según la resolución 8430 de 1993 del Ministerio de Salud, está clasificada como “investigación sin riesgo" puesto que no se realiza ninguna intervención o modificación intencionada de las variables biológicas, fisiológicas, psicológicas o sociales de los individuos.

La obtención del consentimiento de los participantes fue de manera verbal, para ello se les explicó el alcance y los objetivos de la investigación, se les pidió autorización para ser grabados, se les aclaró que la participación era libre y voluntaria, y que si bien se pretendía conocer tanto las generalidades como los detalles de su vida, no se abordarían ciertos temas si decidía que así fuera. Todos dieron su consentimiento.

Las entrevistas transcurrieron en un ambiente de confidencialidad y respeto, fueron grabadas, identificadas con códigos y transcritas para su posterior análisis y los nombres de los personajes fueron cambiados para proteger su identidad. 


\section{BIBLIOGRAFÍA}

Alarcón, J. D. (2008). El ciclo vital familiar. In ASCOFAME (Ed.), Fundamentos en salud familiar (Segunda, p. 83). Bogotá.

Alonso, L. E. (2007). La crisis de la ciudadanía laboral. (Anthropos Editorial, Ed.) (Primera). Barcelona: Anthropos.

Arendt, H. (1982). Los orígenes del totalitarismo.

Arendt, H. (2012). La esfera pública y la privada. In R. Gil Novales (Ed.), La condicion humana (Séptima re, pp. 51-106). Bogotá.

Banco Mundial. (2012). Igualdad de género. Unesco. Retrieved from http://es.unesco.org/creativity/sites/creativity/files/cdis/iguldad_de_genero.pdf

Banco Mundial. (2014). World Development Indicators: Distribution of income or consumption. Retrieved September 29, 2016, from http://wdi.worldbank.org/table/2.9\#

Banco Mundial. (2016). Indice de Gini. Retrieved August 27, 2016, from http://datos.bancomundial.org/indicador/SI.POV.GINI?locations=CO

Batista, A. L. G. (2006). Analisis del Trabajo Infantil en Colombia: perspectiva legal y psicologica. Escuela Superior de Administración Pública. Retrieved from http://cdim.esap.edu.co/BancoMedios/Documentos PDF/análisis del trabajo infantil en colombia perspectiva legal y psicológica.pdf

Bauman, Z. T. de V. de los Á. B. (2011). Trabajo, consumismo y nuevos pobres. (Gedisa, Ed.) (Cuarta rei). Barcerlona, España.

BID. (2004). Los objetivos de desarrollo del milenio en América Latina y el Caribe. Retos, accionesd y compromisos. Washington: Banco Interamericano de Desarrollo. Retrieved from http://www.eclac.cl/mdg/docs/IADBPublicDoc.pdf

Bonilla Mora, A. (2009). Hogares geriátricos distriles: un esfuerzo con mucha demanda. Plaza Capital. Retrieved from http://portal.urosario.edu.co/pla_2004_2008/articulo.php?articulo=1378

Bourdieu, P. (1993). La miseria del mundo. (Fondo de Cultura Económica, Ed.) (Quinta rei). Buenos Aires.

Caballero, C. a., García, M. V., \& Vélez C., S. (2011). Pobreza y desigualdad. Un balance de la informacion disponible. Retrieved from http://library.fes.de/pdffiles/bueros/kolumbien/08400.pdf

Castel, R. (2010). El ascenso de la incertibumbres. Trabajo, protecciones, estatuto de individuo. (F. de C. Económica, Ed.) (Edición en). Buenos Aires.

Castells, M., \& Subirats, M. (2007). Mujeres y hombres ¿un amor imposible? (Alianza Editorial, Ed.). Madrid.

CEPAL. (2005). Una mirada a la protección social desde los derechos humanos y otros contextos 
internacionales.

Retrieved

from

http://books.google.com/books?hl=en\&lr=\&id=41jJPly7SrwC\&oi=fnd\&pg=PA3\&dq=Una+mira $\mathrm{da}+\mathrm{a}+\mathrm{la}+$ protecci? $\mathrm{n}+$ social+desde+los+derechos+humanos+y+otros+contextos+internacionale s\&ots=ZTt45n0_Vt\&sig=KCYUJBdD5ulksm33GDFLOKvYxDw

CEPAL. (2015). La Protección Social de la Población Rural. Bogotá.

Chárriez, M. (2012). Historias de vida: Una metodología de investigación cualitativa. Universidad de Puerto Rico, 50-67.

Congreso de Colombia. (1990). Ley 54 de 1990. Retrieved August 8, 2016, from http://www.alcaldiabogota.gov.co/sisjur/normas/Norma1.jsp?i=30896

Congreso de Colombia. (2012). Ley 1732 de 2012. Bogotá. Retrieved from http://www.prosperidadsocial.gov.co/Documentos compartidos/Ley 1532 de 2012.pdf

Cruz, L. E. (2010). La Constitución Política de 1991 y la apertura económica. Rev. Fac. Cien. Econ., XVIII(1), 269-280.

DANE. (2006). Trabajo Infantil en Colombia 2001 - 2003 - 2005. Retrieved from http://www.dane.gov.co/files/investigaciones/boletines/ech/jobinfantil/presental_2001_2005 .pdf

DANE. (2013). Índice de Pobreza Multidimensional. Bogotá.

DANE. (2015). Estimaciones de población 1985 - 2005 y proyecciones de población 2005 - 2020. Total departamental por área. Retrieved July 13, 2016, from www.dane.gov.co/files/investigaciones/poblacion/.../Municipal_area_1985-2020.xls

DANE. (2016a). Boletín Técnico Pobreza Monetaria y Multidimensional en Colombia 2015. Bogotá. Retrieved

from http://www.dane.gov.co/files/investigaciones/condiciones_vida/pobreza/bol_pobreza_15_.pd $f$

DANE. (2016b). Mercado Laboral: Trabajo Infantil. Retrieved July 30, 2016, from http://www.dane.gov.co/index.php/mercado-laboral/trabajo-infantil

DANE. (2016c). Población de 5 a 17 años y población de 5 a 17 que trabaja según asistencia escolar 2012 - 2015. Retrieved from http://www.dane.gov.co/index.php/mercado-laboral/trabajoinfantil

Díaz, J. (2009). Estado Social de Derecho y Neoliberalismo en Colombia: estudio del Cambio Social a Finales del Siglo XX. Antropología Social, (11), 205-228.

Durán, E. (2007). Los derechos de los niños y niñas: marco general y puntos de debate. In E. Durán Strauch (Ed.), Cátedra Manuel Ancízar: Derechos de los niños y las niñas. Debates, realidades y perspectivas (Centro de, pp. 39-56). Bogotá.

Durán, E. (2010). Reflexiones sobre el seguimiento a los derechos de niños, niñas y adolescentes. In C. Editores (Ed.), Monitoreo de Derechos de la Niñez y la Adolescencia. Reflexiones sobre lo aprendido. Bogotá. 
Echeverri Angel, L. (2013). La familia en Colombia. Transformaciones y prospectiva. Cuadernos Del CES, 53(9), 1689-1699. http://doi.org/10.1017/CBO9781107415324.004

El Espectador. (2015, August 12). Alcalde de Chameza (Casanare) convirtió una ambulancia en su vehículo particular. El Espectador. Bogotá. Retrieved from http://www.elespectador.com/noticias/judicial/alcalde-de-chameza-casanare-convirtio-unaambulancia-su-articulo-578698

El Espectador. (2016, July 21). Plantón contra "las deudas impagables" del Icetex. El Espectador, pp. 1-4. Bogotá. Retrieved from http://www.elespectador.com/noticias/educacion/plantoncontra-deudas-impagables-del-icetex-articulo-644535

El País. (2016, June 20). Colombia es el país con mayor desplazamiento forzado en el mundo: ONU. El País. Cali. Retrieved from http://www.elpais.com.co/elpais/colombia/noticias/colombia-paiscon-mayor-numero-desplazados-internos-onu

El Tiempo. (1994, January 14). Asesinada alcaldesa de Chámesa Casanare. El Tiempo. Bogotá. Retrieved from http://www.eltiempo.com/archivo/documento/MAM-13744

El Tiempo. (2001, March 20). Sigue el temor en Chámeza. El Tiempo. Bogotá. Retrieved from http://www.eltiempo.com/archivo/documento/MAM-585484

Erikson, E. (1933). Ciclo vital completo.

Esping-Andersen, G. (2004). La política familiar y la nueva demografia. ICE, (815), 45-59. Retrieved from http://www.revistasice.com/CachePDF/ICE_815_4560_E2DBEE4DEAB4141D2AED0DDD823952A1.pdf

Esping-Andersen, G. (2009). Incomplete Revolution: Adapting Welfare States to Women's New Roles. Barcerlona, España.

Ezcurra, A. M. (1998). ¿Qué es el neoliberalismo? Evolución y límites de un modelo excluyente. (Instituto de Estudios y Acción Social. IDEAS, Ed.). Buenos Aires.

Fedesarrollo, \& Fundación Saldarriaga Concha. (2015). Misión Colombia Envejece. Bogotá: Editorial Saldarriga Concha. http://doi.org/10.1017/CBO9781107415324.004

Fleury, S. (2007). Salud y Democracia en Brasil Valor Público y Capital Institucional en el Sistema Único de Salud. Salud Colectiva, 2(3), 147-157. Retrieved from http://www.scielo.org.ar/pdf/sc/v3n2/v3n2a04.pdf

Galves S, M. I., \& Rodrígez L, M. C. (2005). La importancia del juego. Jugando juntos: Un tercer lugar para niños de 3 a 6 años y su familia. Universidad de las Américas de Puebla, Puebla. Retrieved from http://catarina.udlap.mx/u_dl_a/tales/documentos/ldf/galvez_s_mi/capitulo3.pdf

Giraldo, C. (2008). Del ciudadano al cliente: Cuidadanía y derechos sociales en América Latina. Nova et Vera, (Número 60), 11-21.

Gobierno de Colombia. (2015). Abecé de Más Familias en Acción. Retrieved August 17, 2016, from http://www.urnadecristal.gov.co/gestion-gobierno/abc-mas-familias-en-accion

Gómez I, M. C. (2006). La historia del Estado Social de Derecho. In Universidad de Antioquia (Ed.), 
Colombia Estudios de Derecho (Primera, pp. 73-99). Medellín.

ICETEX. (2016). Informe de gestión 2015. ICETEX. Bototá. Retrieved from https://www.icetex.gov.co/dnnpro5/Portals/0/Documentos/La Institucion/IINFORME_GESTION_baja.pdf

IGAC. (2012). Atlas de la Distribución de la Propiedad Rural en Colombia - 2012. Retrieved from http://www.igac.gov.co/wps/wcm/connect/8beae7804dc8d75abb1efb36b39898f6/1_notas_s obre_la_evolucion_historica_con_cubierta_1.pdf?MOD=AJPERES

La República. (2013, September 18). Créditos del Icetex , una oportunidad que sale cara. La República, pp. 7-10. Bogotá. Retrieved from http://www.larepublica.co/finanzas/créditos-del-icetex-unaoportunidad-que-sale-cara_61496

Lippman, L., Wilcox, W. B., \& Ryberg, R. (2014). World Family Map. Retrieved from http://worldfamilymap.org/2014/wp-content/uploads/2014/09/WorldFamilyMapESP.pdf

Lo Vuolo, R. (2009). Una observación heterodoxa del complejo, híbrido e inestable régimen de acumulación de Argentina. In M. y Dávila (Ed.), Distribución y Crecimiento. Una controversia persistente. (pp. 185-2008). Buenos Aires: Centro Interdisciplinario para el Estudio de Políticas Públicas. Retrieved from http://www.econ.uba.ar/www/institutos/economia/ceped/actividades/Seminario Interdisciplinario/Mesa Debate 1 - Macro/Lo Vuolo.pdf

Marshall, A. (1997). CIUDADANIA Y CLASE SOCIAL Thomas Humphrey Marshall. Reis, 79, 297-344. Retrieved from http://www.jstor.org/discover/10.2307/40184017?uid=3737784\&uid=2134\&uid=2\&uid=70\&u id $=4 \&$ sid $=21104754476317$

Ministerio de Educación Nacional. (2013). Observatorio Laboral. Retrieved July 13, 2013, from http://www.graduadoscolombia.edu.co/html/1732/w3-article-344799.html

Ministerio de Educación Nacional. (2016). Tasa de cobertura de Educación Superior en Colombia. Retrieved June 13, 2016, from http://www.mineducacion.gov.co/sistemasdeinformacion/1735/w3-propertyname-2672.html

Ministerio del Trabajo. (2012). Total nacional ocupados por sexo según posicioón ocupacional 2007 2011. Retrieved from http://www.mintrabajo.gov.co/empleo/indicadores-del-mercadolaboral.html

Ministerio del Trabajo. (2013). Colombia Mayor Consorcio 2013. Retrieved August 21, 2013, from https://colombiamayor.co/programa_psap.html

Moyn, S. (2015). La Última Utopía : Los Derechos Humanos en la Historia (Traducción).

Múnera, J. R. Á. (2007). Contradicciones entre el modelo de desarrollo neoliberal vigente en Colombia y la Constitución Política benefactora de 1991. Revista FACULTAD DE TRABAJO SOCIAL, 23, 121135.

Ocampo, J. A. C. (1987). Historia económica de Colombia. (Siglo XXI, Ed.) (Segunda ed). Bogotá. 
ONU. (1989). Convención sobre los Derechos del Niño, 44. Retrieved from http://www2.ohchr.org/spanish/law/crc.htm

Organización de las Naciones Unidas. (1948). Declaración Universal de los Derechos Humanos.

Oscuro, C. (2016, July 25). La ley que frenaría los cobros desmedidos del Icetex. El Espectador, pp. 47. Bogotá. Retrieved from http://www.elespectador.com/noticias/nacional/ley-frenaria-loscobros-desmedidos-del-icetex-articulo-645310

Parola, R. (2004). Reseña bibliográfica. Revista Confluencia, 1(4), 1-6.

Párraga, C. L. A., Abello, M. C., \& Rojas, A. L. C. (2013). Estrategia de atención integral a la primera infancia: Fundamentos políticos, técnicos y de gestión. Presidencia de la República - De Cero a Siempre.

Portafolio. (2013). En Colombia hay 750.000 trabajadores en el sector doméstico. Portafolio, 13 mayo. Retrieved from http://www.portafolio.co/economia/finanzas/colombia-hay-750-000trabajadores-sector-domestico-80708

Registro Único de Víctimas. (2016). Víctimas por tipo de hecho victimizante. Retrieved July 15, 2016, from http://rni.unidadvictimas.gov.co/RUV

Rights, U. for H. (2008). Unidos por los derechos humanos. Retrieved May 1, 2016, from http://www.humanrights.com/es_ES/about-us/what-is-united-for-human-rights.html

Rivera, \& Aragón, Á. (2012). CIUDADANÍA Y DERECHOS SOCIALES: LAS DIFICULTADES DE LA CIUDADANÍA SOCIAL. (Spanish). Citizenship and Social Rights: The Difficulties of Social Citizenship. (English), 9(18), 141-159. Retrieved from http://search.ebscohost.com/login.aspx?direct=true\&db=ofm\&AN=76110079\&lang=es\&site= ehost-live

Rodríguez, D., \& Cepeda, E. (2011). Concentración de la tierra en Colombia. Comunicaciones En Estadística, 4(1), 29-42. http://doi.org/http://dx.doi.org/10.15332/s2027-3355.2011.0001.02

Rosanvallon, P. T. H. P. (1995). La nueva cuestión social. Título original: La Nouvelle Question Sociale. (Éditions du Seul, Ed.) (Edición en). Buenos Aires: Manantial.

Secretaría de Distrital de Integración Social. (2015). Subdirección para la vejez. Envejecimiento digno, activo y feliz. Retrieved July 21, 2016, from http://www.integracionsocial.gov.co/index.php/vejez

Sunkel, G. (2006). El papel de la familia en la protección social en América Latina. Serie Políticas Sociales, CEPAL (Vol. 120).

Talero B, J. (2015). Una comparación del gasto por tres niveles de ingreso para Colombia bajo una estimación del sistema de ecuaciones de demanda Working y Leser y del sistema lineal de gasto extendido 2008 Jorge Andrés Talero Bernal 1. Revista CIFE: Lecturas de Economía Social, 17(15), $1-39$.

Todaro, R., \& Yáñez, S. (2004). El trabajo se transforma. Relaciones de producción y relaciones de género. (Centro de Estudios de la Mujer, Ed.), El trabajo se transforma: Relaciones de produccion 
y relaciones de género. Santiago, Chile. Retrieved from http://www.cem.cl/pdf/trabajo_interior.pdf

Torrado P., M. C., \& Anzelín Z., I. C. (2009). La primera infancia en la agenda local colombiana. Análisis y recomendaciones. In M. C. Torrado Pacheco (Ed.), Retos para las políticas públicas de primera infancia (pp. 29-65). Bogotá: Universidad Nacional de Colombia. Facultad de Ciencias Humanas. Observatorio sobre infancia.

Torrado p, M. C., \& Bejarano N, D. C. (2009). Aportes al seguimiento y evaluación de las políticas públicas para la primera infancia. In U. N. de C. CES. Centro de Estudios Sociales (Ed.), Retos para las políticas públicas de primera infancia (pp. 101-113). Bogotá.

Unesco. (1980). El niño y el juego - Planteamientos teóricos y aplicaciones pedagógicas. Unesco. Retrieved from http://unesdoc.unesco.org/images/0013/001340/134047so.pdf

Universidad Nacional De Colombia. (2014). Indicadores y estadísticas Universidad Nacional De Colombia- 2014, 147.

Van der Gaag, J. (2003). Del desarrollo infantil al desarrollo humano. In I. C. de B. F. ICBF, Alcaldía Mayo de Bogotá, Departamento Administrativo de Bienestar Social, Save the Children, Fondo de Naciones Unidas para la Infancia, \& Centro Internacional de Educación y Desarrollo Humano (Eds.), Primera infancia y desarrollo. El desafío de la década. 